\title{
Parametric Sensitivity Study of Operating and Design Variables in Wellbore Heat Exchangers
}

\author{
Gopi Nalla \\ G. Michael Shook \\ Gregory L. Mines \\ K. Kit Bloomfield
}

May 2004

Idaho National Engineering and Environmental Laboratory Bechtel BWXT Idaho, LLC 


\section{DISCLAIMER}

This report was prepared as an account of work sponsored by an agency of the United States Government. Neither the United States Government nor any agency Thereof, nor any of their employees, makes any warranty, express or implied, or assumes any legal liability or responsibility for the accuracy, completeness, or usefulness of any information, apparatus, product, or process disclosed, or represents that its use would not infringe privately owned rights. Reference herein to any specific commercial product, process, or service by trade name, trademark, manufacturer, or otherwise does not necessarily constitute or imply its endorsement, recommendation, or favoring by the United States Government or any agency thereof. The views and opinions of authors expressed herein do not necessarily state or reflect those of the United States Government or any agency thereof. 


\section{DISCLAIMER}

Portions of this document may be illegible in electronic image products. Images are produced from the best available original document. 


\title{
Parametric Sensitivity Study of Operating and Design Variables in Wellbore Heat Exchangers
}

\author{
Gopi Nalla
}

G. Michael Shook

Gregory L. Mines

K. Kit Bloomfield

May 2004

Idaho National Engineering and Environmental Laboratory Idaho Falls, Idaho 83415

Prepared for the

U.S. Department of Energy

Office of Energy Efficiency and Renewable Energy

Under DOE Idaho Operations Office

Contract DE-AC07-99ID13727 



\section{ABSTRACT}

This report documents the results of an extensive sensitivity study conducted by the Idaho National Engineering and Environmental Laboratory. This study investigated the effects of various operating and design parameters on wellbore heat exchanger performance to determine conditions for optimal thermal energy extraction and evaluate the potential for using a wellbore heat exchanger model for power generation. Variables studied included operational parameters such as circulation rates, wellbore geometries and working fluid properties, and regional properties including basal heat flux and formation rock type. Energy extraction is strongly affected by fluid residence time, heat transfer contact area, and formation thermal properties. Water appears to be the most appropriate working fluid. Aside from minimal tubing insulation, tubing properties are second order effects.

On the basis of the sensitivity study, a best case model was simulated and the results compared against existing low-temperature power generation plants. Even assuming ideal work conversion to electric power, a wellbore heat exchange model cannot generate $200 \mathrm{~kW}(682.4 \mathrm{e}+3 \mathrm{BTU} / \mathrm{h})$ at the onset of pseudosteady state. Using realistic conversion efficiency, the method is unlikely to generate $50 \mathrm{~kW}(170.6 \mathrm{e}+3 \mathrm{BTU} / \mathrm{h})$. 
- 


\section{ACKNOWLEDGMENTS}

The authors wish to thank DOE for funding this project; Raymond LaSala, whose interest in evaluating the feasibility of wellbore heat exchangers motivated this critical study; John Finger from Sandia National Laboratories for his valuable contributions; and our program manager, Joel Renner, for providing support and suggestions for this project. 


\section{CONTENTS}

ABSTRACT.

iii

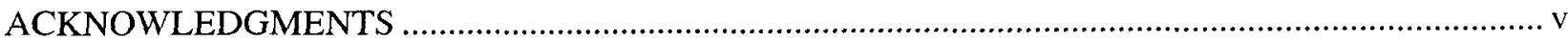

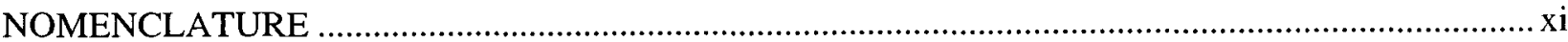

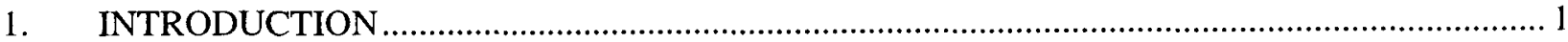

$1.1 \quad$ Wellbore Heat Exchanger Concept and Description .................................................... 1

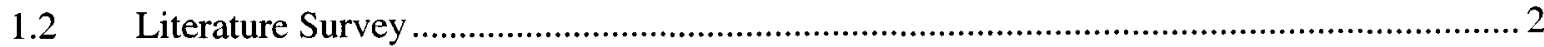

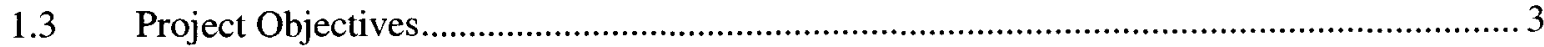

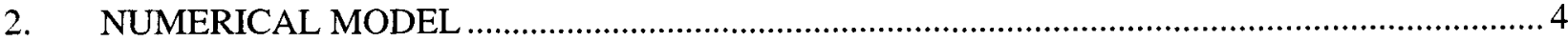

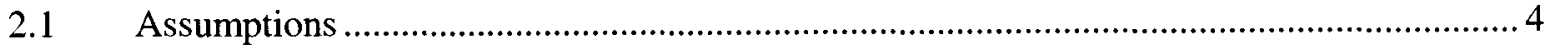

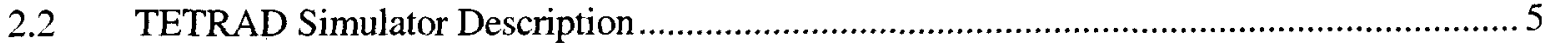

2.2.1 Special Case of Wellbore Heat Exchanger..................................................... 6

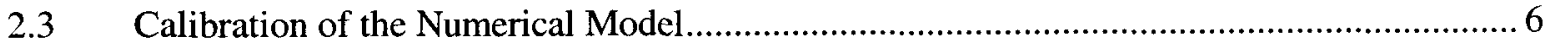

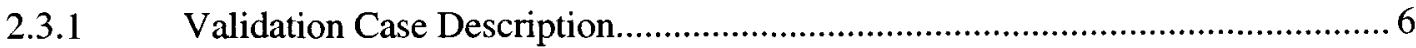

2.3.2 Comparison Results ..............................................................................

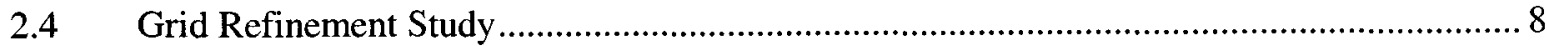

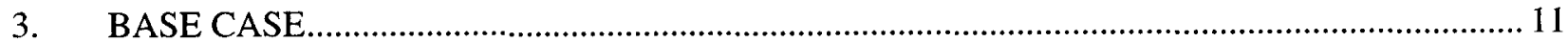

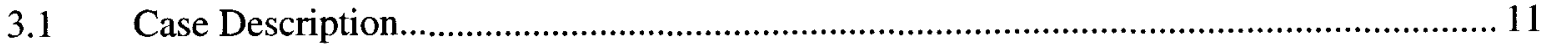

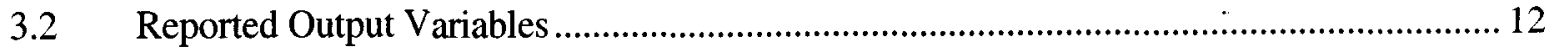

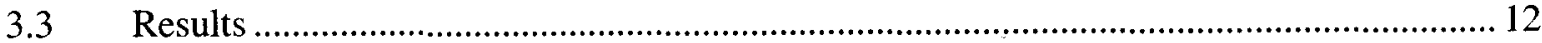

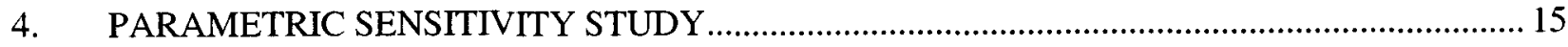

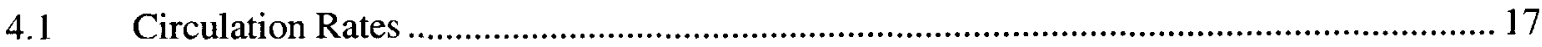

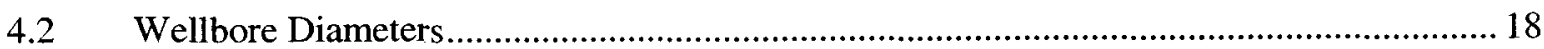

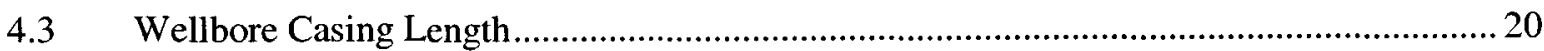

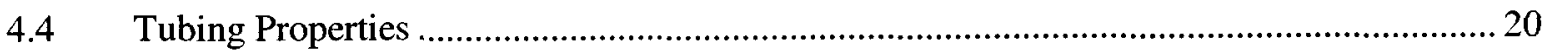

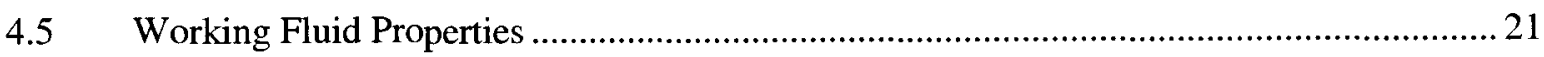




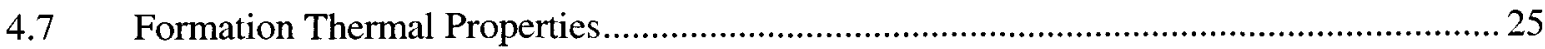

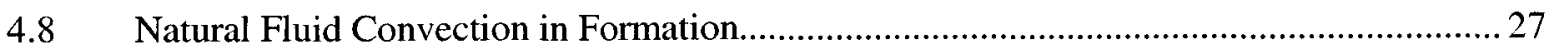

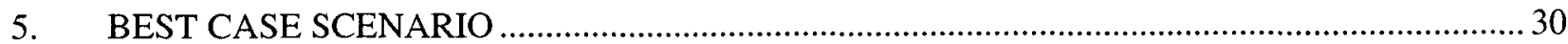

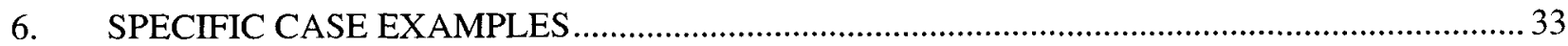

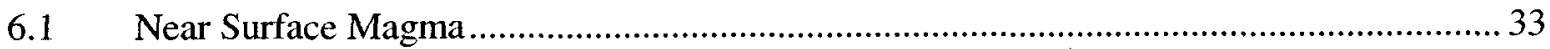

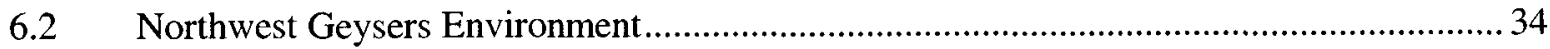

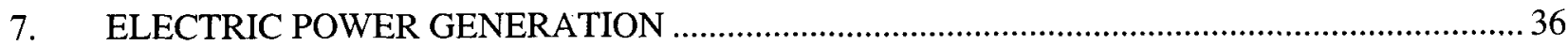

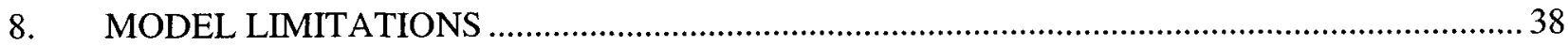

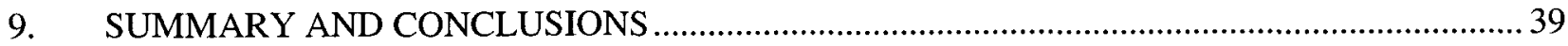

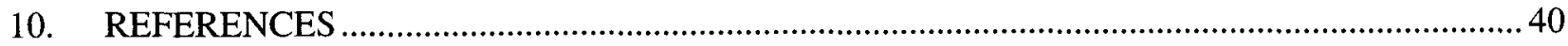

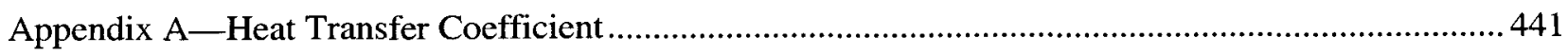

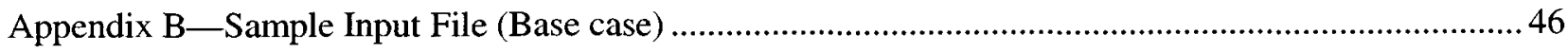

Appendix C - Calculation of the Average Formation Heat Transfer Due to Conduction and Proof of the

Primary Effect of Wellbore Depth Compared to the Secondary Effect of Geothermal Gradient .... 54

\section{FIGURES}

Figure 1. Schematic diagram of the wellbore heat exchanger. 1

Figure 2. Numerical model of wellbore heat exchanger (not to scale). 4

Figure 3. Comparison of the produced fluid temperature histories from TETRAD and GEOTEMP at 100 and $20 \mathrm{gpm}$ circulation rates, showing the convergence at later time. .8

Figure 4. Schematic diagram of the areal gridding used in the numerical model. 9

Figure 5. Areal grid refinement plot showing converged solution for 29 grids....................................... 9

Figure 6. Vertical grid refinement showing converged solution at grid block size of $30.5 \mathrm{~m} \ldots \ldots \ldots \ldots \ldots \ldots . . . . .10$

Figure 7. Diagram describing the wellbore geometry of the base case (to scale) ................................ 12

Figure 8. Produced fluid temperature history for the base case ....................................................... 13

Figure 9. Temperature profile in the radial direction in the wellbore and formation at three depths below land surface and at 5 days. 
Figure 10. Temperature profile in the radial direction in the wellbore and formation at three depths below land surface and at 500 days (onset of PSS).

Figure 11. Ideal work extraction rate history plot for the base case.

Figure 12. Fluid return temperature history for circulation rates of 20, 100, and $500 \mathrm{gpm}$ showing the highest PSS return temperature for the $20 \mathrm{gpm}$ case.

Figure 13. Ideal work extraction rate for circulation rates of 20,100 , and $500 \mathrm{gpm}$ with the $100 \mathrm{gpm}$ case having the highest ideal work extraction rate.

Figure 14. Plot of produced fluid temperature and ideal work extraction rates as a function of circulation rate at 500 days (PSS) illustrating an optimal circulation rate of $100 \mathrm{gpm}$.

Figure 15. Fluid return temperature history for two different wellbore diameters The larger annular volume facilitates larger fluid residence times and higher temperature gain.

Figure 16. Ideal work extraction rate histories for the two wellbore diameters. The $660.4 \mathrm{~mm}$ wellbore diameter has the higher ideal work extraction rate.

Figure 17. Effluent fluid temperature for varying wellbore casing lengths.....

Figure 18. Effluent fluid temperature history plot for different tubing properties (insulation thermal conductivity and tubing diameter) at a circulation rate of $100 \mathrm{gpm}$

illustrating the insignificant effect of tubing properties.

Figure 19. Produced fluid temperature histories for different working fluid cases showing that fluids with larger volumetric heat capacity have lower temperatures.

Figure 20. Thermal energy flow rate history for different working fluid cases.

Figure 21. Pseudosteady-state effluent fluid temperature and thermal energy output rate as a function of volumetric heat capacity.

Figure 22. Effluent fluid temperature history plot for varying basal heat flux. The lowest basal heat flux case has the highest PSS effluent fluid temperature for fixed bottomhole temperature.

Figure 23. Ideal work extraction rate as a function of basal heat flux. The lowest basal heat flux case has the highest ideal work extraction rate for fixed bottomhole temperature. 25

Figure 24. Produced fluid temperature history for different formation thermal properties. The shale case had the highest PSS effluent fluid temperature, while the Bandera Sandstone case had the lowest effluent fluid temperature.

Figure 25. Pseudosteady state ideal work extraction rate plotted as a function of $K / \kappa^{1 / 2}$. The PSS ideal work rate correlates as a function of $\mathrm{K} / \mathrm{\kappa}^{1 / 2}$.

Figure 26. Initial formation temperature profiles for the case with and without convection. 28

Figure 27. Fluid vertical interstitial velocities in the convection case at 500 days. 28 
Figure 28. Effluent fluid temperature history comparison for the formation convection case vs. no convection case.

Figure 29. Ideal work extraction rate history comparison for the formation convection case vs. no convection case

Figure 30. Produced fluid temperature history for the best case ..................................................... 31

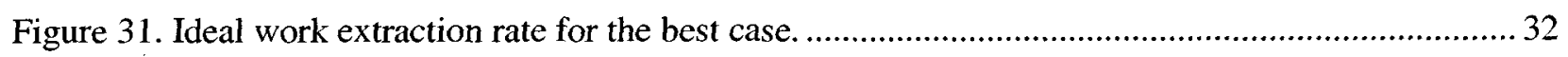

Figure 32. Produced fluid temperature history for the near surface magma case. The effluent fluid returns quickly to injection temperature due to its small residence time.

Figure 33. Ideal work extraction rate history for the near surface magma case showing the low PSS ideal work rate due to low effluent fluid temperature. 34

Figure 34. Produced fluid temperature history for the northwest geysers case. 35

Figure 35. Ideal work extraction rate history for the northwest geysers case. 35

Figure 36. Potential net power output vs. flow rate (Nichols 1986) 37

\section{TABLES}

Table 1. Thermal properties used for the calibration study case 7

Table 2. Base case description. 11

Table 3. Sensitivity study parameters and ranges of the analysis. 15

Table 4. Data summary for the sensitivity study cases. . 16

Table 5. Thermal properties used for the working fluid sensitivity study. 22

Table 6. Thermal properties used for the formation thermal property sensitivity study. 26

Table 7. Summary of sensitivity study results at PSS..... 30

Table 8. Best case description of well geometry and case parameters. 31

Table 9. Commercial low-temperature operating specifications 36 


\section{NOMENCLATURE}

A

$\mathrm{C}_{\mathrm{ig}} \quad$ component $i$ concentration in gaseous phase

$\mathrm{C}_{\text {is }} \quad$ component $i$ concentration in solid phase

$\mathrm{C}_{\mathrm{jw}} \quad$ component $i$ concentration in aqueous phase

g gravity vector

$\mathrm{H}_{\mathrm{iw}} \quad$ component $i$ enthalpy in aqueous phase

$\mathrm{H}_{\mathrm{ig}} \quad$ component $i$ enthalpy in gaseous phase

$\mathrm{H}_{\mathrm{is}} \quad$ component $i$ enthalpy in solid phase

$\mathrm{H}_{\mathrm{w}} \quad$ aqueous phase enthalpy

$\mathrm{H}_{\mathrm{g}} \quad$ gaseous phase enthalpy

$\mathrm{H}_{\mathrm{s}} \quad$ solid phase enthalpy

$\overrightarrow{\vec{k}}$

$\overrightarrow{\vec{K}}_{i w}$

component $i$ dispersion in aqueous phase

$\overrightarrow{\vec{K}}_{i s}$

$\mathrm{K}_{\mathrm{Tt}}$

$m_{\text {in }}$

$\mathrm{P}_{\mathrm{j}} \quad$ phase $j$ pressure

$\mathrm{P}_{\mathrm{w}} \quad$ aqueous phase pressure

$\mathrm{q}_{\mathrm{i}} \quad$ component $i$ source/sink term

$\mathrm{q}_{\mathrm{E}} \quad$ energy source/sink term

$\mathrm{S}_{\mathrm{g}} \quad$ gaseous phase saturation

$\mathrm{S}_{\mathrm{w}} \quad$ aqueous phase saturation

$T \quad$ temperature 


$\begin{array}{ll}\overrightarrow{u_{g}} & \text { gaseous phase advective flux } \\ \overrightarrow{u_{w}} & \text { aqueous phase advective flux } \\ \mathrm{u}_{\mathrm{wZ}} & \text { liquid water velocity in the z-direction } \\ \mathrm{U}_{\mathrm{w}} & \text { aqueous phase internal energy } \\ \mathrm{U}_{\mathrm{g}} & \text { gaseous phase internal energy } \\ \mathrm{U}_{\mathrm{s}} & \text { solid phase internal energy } \\ \mathrm{U}_{\mathrm{iw}} & \text { component } i \text { internal energy in aqueous phase } \\ \mathrm{U}_{\mathrm{ig}} & \text { component } i \text { internal energy in gaseous phase } \\ \mathrm{U}_{\mathrm{is}} & \text { component } i \text { internal energy in solid phase }\end{array}$

\section{Greek letters}

$\phi \quad$ porosity

$\mu_{\mathrm{w}} \quad$ aqueous phase viscosity

$\rho_{g} \quad$ gaseous phase density

$\rho_{j} \quad$ phase $j$ molar density

$\rho_{s} \quad$ solid phase molar density

$\rho_{w} \quad$ aqueous phase molar density 


\section{Parametric Sensitivity Study of Operating and Design Variables in Wellbore Heat Exchangers}

\section{INTRODUCTION}

\subsection{Wellbore Heat Exchanger Concept and Description}

Although engineered geothermal systems (EGSs) are typically thought of as being either permeability-limited or fluid-limited, in an extreme EGS condition there is neither sufficient permeability to induce flow nor working fluid to circulate through the rock formation. Under this condition, heat extraction via circulation in a wellbore has been proposed as a means of geothermal power generation or for direct use applications (Kohl, Brenni, and Eugster 2002; Lund 2003).

The wellbore heat extraction (WBHX) concept can be described as injecting and circulating cold fluid down the annulus and up the tubing for production at the surface. There exists no contact between the working fluid in the well and the reservoir other than heat conduction across the well perimeter itself. Figure 1 shows a schematic diagram of the wellbore heat exchanger model. The wellbore consists of the tubing, insulation, casing, and cement. The well is cased and cemented to a certain depth, and the remaining portion of the well is retained as an open hole. The tubing is insulated and extends to the bottom of the wellbore. The fluid is injected into the annulus. As it descends it gains heat from the formation due to conduction. The hot fluid then rises up through the tubing to the surface. Power generation can take place either at the surface or downhole, but as is described in a later section, the temperature differences between the two are minimal because of the high flow rate through the tubing.

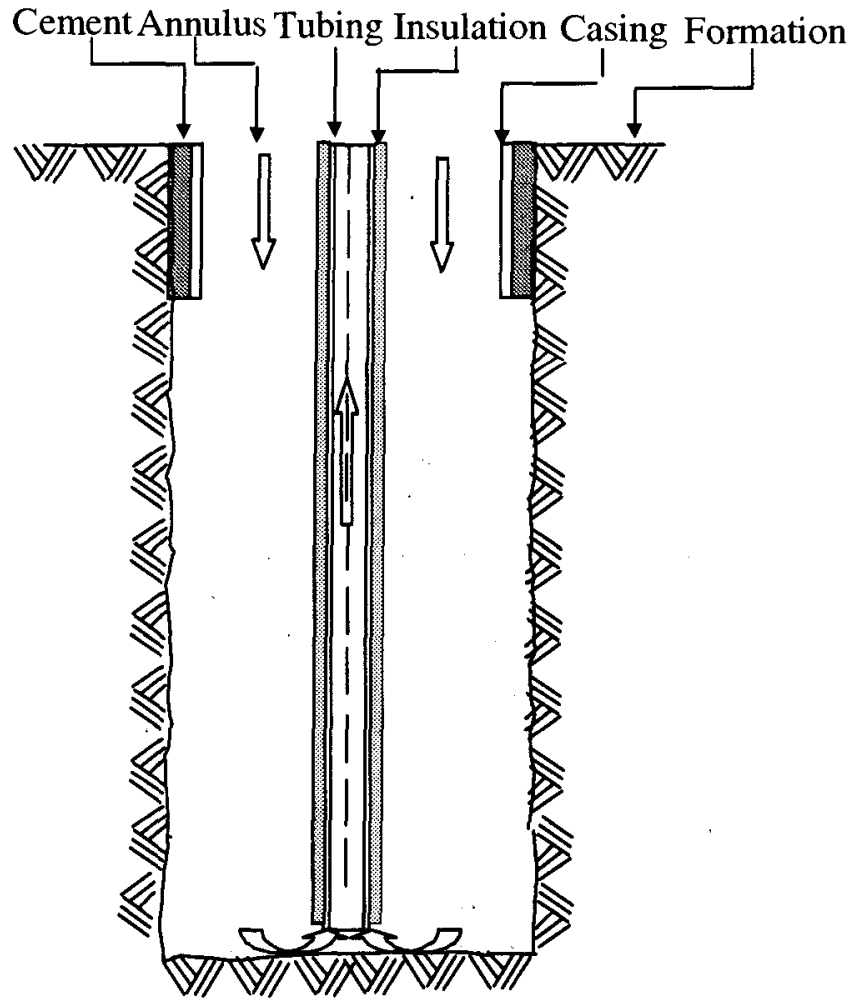

Figure 1. Schematic diagram of the wellbore heat exchanger. 
Our study evaluated the potential for power generation using the WBHX concept. We examined operational parameters such as circulation rates, well geometry and depth, working fluids, and regional variables such as heat flux and formation thermal properties. This work is an extension of preliminary studies conducted at Sandia National Laboratories (SNL; Finger 2003 [personal communication]), and comprises a comprehensive numerical evaluation of the proposed method for geothermal power production.

Unsuccessful wells previously drilled in the pursuit of permeable resources for oil production or geothermal fluids are potentially reusable as wellbore heat exchangers in regions where there is a reasonable thermal energy content. The low capital costs of an existing well makes the wellbore heat exchanger an attractive option. The two main heat transfer processes involved are heat transfer from the formation to the wellbore by thermal conduction and heat transfer by the fluid through advection. The fluid advection process is faster when compared to thermal conduction from the formation to the wellbore. This report describes the physical and numerical aspects of the wellbore heat exchanger model.

\subsection{Literature Survey}

Kohl et al. (2002) analyzed the operation of a 2,302-m (7,552.5-ft)-deep borehole heat exchanger at Weggis, Switzerland, which was being used for space heating and domestic hot water purposes. They concluded that the heat exchanger was not being operated at optimal conditions, and that the produced thermal energy rate could be increased from the present value of $40 \mathrm{~kW}(136.5 \mathrm{e}+3 \mathrm{BTU} / \mathrm{h})$ to $180 \mathrm{~kW}$ $(614.2 \mathrm{e}+3 \mathrm{BTU} / \mathrm{h})$ by optimizing the circulation rate. After conducting a numerical sensitivity analysis on the circulation and recovery period cycles, they concluded that the long-term performance would not be affected by a variation of the cycle interval, provided they used identical total circulation, recovery periods, and identical flow rates. Based on a sensitivity study of insulation thermal conductivity and circulation temperatures, they concluded that a higher degree of insulation on the tubing and lower injection temperatures would increase the thermal power that could be extracted from borehole heat exchanger systems. In our project, we conducted a more extensive sensitivity study of all operating and design variables, including the circulation rate and tubing properties.

Lund (2003) provides information on the use and installation of downhole heat exchangers for direct heating applications. Lund's paper demonstrates that wellbore heat exchangers are a viable option for direct heating applications.

Abe et al. (1999) summarizes the present status of hot dry rock systems and their economical aspects. Their paper made several important observations about the thermal energy production and its conversion to electrical energy in hot dry rock systems. According to their study, a resource that can return water to the surface at temperatures of $150^{\circ} \mathrm{C}\left(302^{\circ} \mathrm{F}\right)$ or higher appear to be a minimum requirement for electrical power production using current technologies; however, temperatures of about $80-90^{\circ} \mathrm{C}\left(176-194^{\circ} \mathrm{F}\right)$ could be practical for direct use applications. They also suggest that even a small commercial geothermal power plant producing, for instance, $5 \mathrm{MW}(1.706 \mathrm{e}+7 \mathrm{BTU} / \mathrm{h})$ of electricity from water at $150^{\circ} \mathrm{C}\left(302^{\circ} \mathrm{F}\right)$ would require flow rates on the order of $2378 \mathrm{gpm}(137.5 \mathrm{~kg} / \mathrm{s})$. These produced fluid temperature requirements for commercial geothermal power production also apply to wellbore heat exchanger systems.

Kanev et al. (1997) conducted numerical investigations to study the impact of heat loss from the geothermal wellbore on produced fluid temperatures and pressures. Their study identifies flow rate as a key parameter in determining the wellhead conditions, with elapsed time and geothermal gradient playing secondary roles. 
Ramey (1961) derived an approximate solution to the wellbore heat transmission problem that could be used to predict the bottomhole temperature of the fluid when it is injected at the surface. The assumptions used in deriving the analytical solution were that (a) heat flows in the radial direction in the formation; (b) heat transmission in the wellbore is rapid compared to heat flow in the formation, hence, could be represented by steady-state solutions; and (c) physical and thermal properties of the earth and wellbore fluids do not vary with temperature.

Bobok and Toth (2002) developed a mathematical model of dry (wellbore) hole heat exchangers and conducted numerical simulation to predict its thermal behavior. To determine the heat flux around the well, the mathematical model developed by Bobok and Toth used a time function that was derived from solutions for radial heat conduction from an infinitely long cylinder (Ramey [1961]). Their numerical simulation study conducted for the circulation rates showed that with increasing circulation rates, the outflowing water temperature decreases, and that only small-scale utilizations could be based on the dry hole heat exchangers.

A more complex and transient system was solved for using the numerical simulator TETRAD (Vinsome and Shook, 1993), which uses fully implicit numerical methods. A parametric sensitivity study was conducted to determine the thermal behavior of wellbore heat exchangers.

\subsection{Project Objectives}

Our main objectives for this project were to:

- Determine the effects of parameter variation on wellbore heat exchanger performance by comparing and analyzing the effluent fluid temperature and ideal work extraction rate from each case study

- Evaluate the viability of electric power generation in wellbore heat exchangers by determining the power generated from the best case scenario that was constructed using the optimal design parameters and operating conditions obtained from the parametric sensitivity study 


\section{NUMERICAL MODEL}

We used a multiphase, multicomponent, three-dimensional TETRADv13.3 simulator to conduct numerical investigations. Figure 2 shows a schematic of the wellbore heat exchanger. The well model in TETRAD is coded as a source/sink term, but to simulate the WBHX phenomena for this study, we constructed a complex numerical model with each of the grid properties and parameters assigned so as to represent the various elements of the wellbore and formation. The different elements of the wellbore heat exchanger model are the tubing, insulation, casing, cement, and formation. With some exceptions (natural fluid convection effects case) the four sides of the domain are surrounded by no-flow boundaries. A basal heat flux boundary condition is given at the base of the domain and a surface heat loss boundary condition is given at the top of the domain to maintain isothermal conditions. The circulation fluid mass rate and temperature are specified as input. Negligible resistance to flow in the z-direction in a wellbore heat exchanger was made possible by assigning very high vertical permeabilities. Lateral mixing of the working fluid in the cells representing the annulus and tubing was allowed. The transmissibility across the inner tubing-liquid interface, outer insulation-liquid interface, and formation-wellbore interface was set to a very small value to prevent communication between the formation and wellbore.

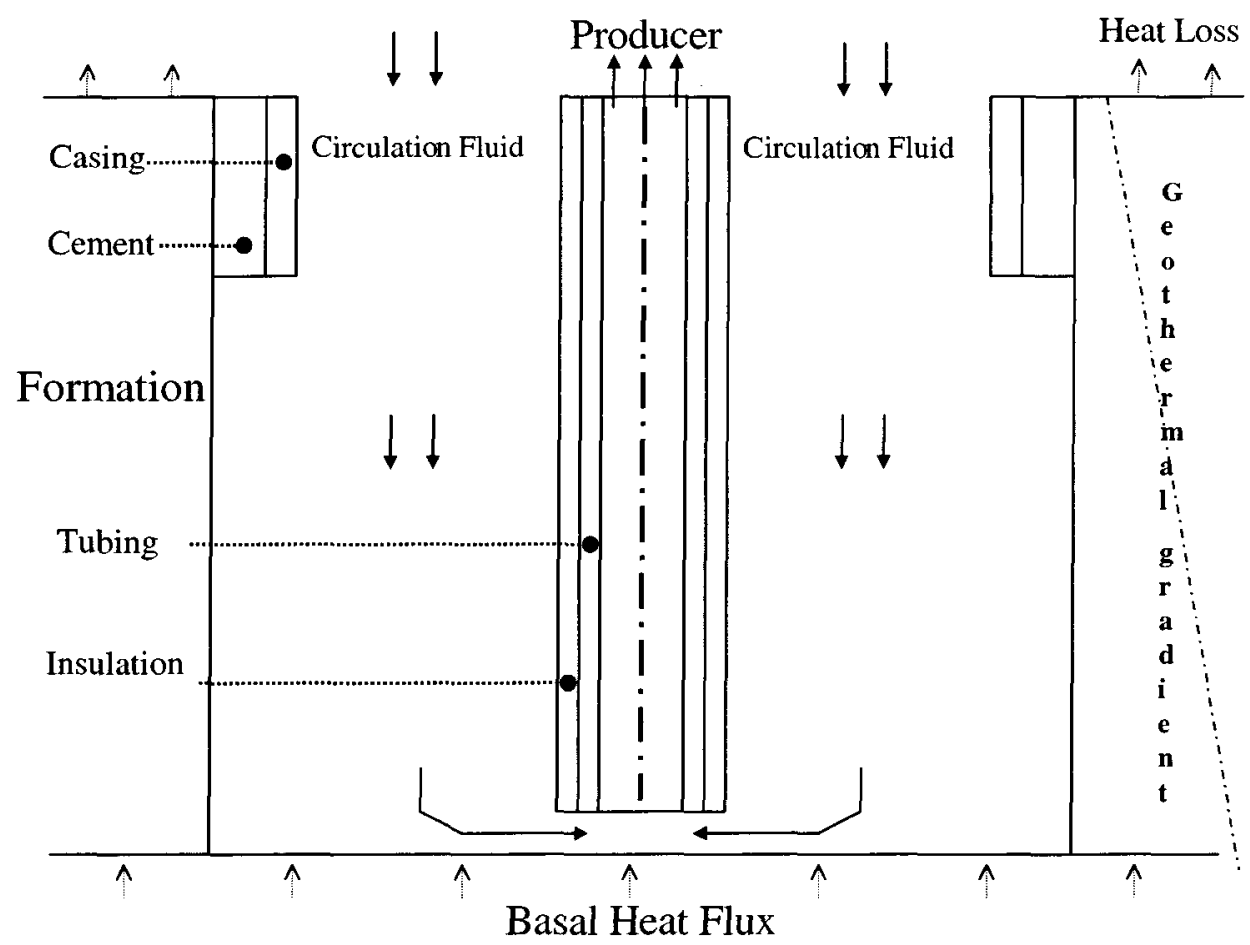

Figure 2. Numerical model of wellbore heat exchanger (not to scale).

\subsection{Assumptions}

We used the following assumptions in developing the numerical wellbore model:

- Thermal conduction and advection are the predominant heat transfer mechanisms in the wellbore and formation. Radiation heat transfer, considered negligible, was not included. Heat transfer, as described by Newton's law of cooling at the wall-fluid interface, is treated as a heat conduction term. 
- Newtonian working fluid is circulated in the wellbore. Fluid density is variable as a function of pressure and temperature.

- Working fluid does not enter the formation and does not mix with the in situ reservoir fluids.

- Formation thermal properties are constant.

- Two phase flow regimes in the wellbore were not incorporated. Only the liquid phase working fluid case was studied.

- The frictional pressure drop loss in the wellbore was neglected.

- Local thermal equilibrium exists.

\subsection{TETRAD Simulator Description}

TETRAD is a multiphase, multicomponent, three-dimensional reservoir simulator that has been extensively used to model flow in porous/fractured media (Vinsome and Shook, 1993). Two phases (water and gas phases) and $N_{C}$ components exist in the geothermal model, which may partition among any of the phases. There will be $N_{C}$ molar conservation equations and one energy conservation equation.

The general mass conservation equation for component $i$ can be written as:

$$
\begin{aligned}
& \frac{\partial}{\partial t}\left(\phi\left(S_{w} \rho_{w} C_{i w}+S_{g} \rho_{g} C_{i g}\right)+(1-\phi) \rho_{s} C_{i s}\right)+ \\
& \vec{\nabla} \bullet\left[\left(\left(\rho_{w} \vec{u}_{w} C_{i w}-\phi \rho_{w} S_{w^{\prime}} \overrightarrow{\vec{K}}_{i w} \bullet \vec{\nabla} C_{i w}\right)\right)+\left(\left(\rho_{g} \vec{u}_{g} C_{i g}-\phi \rho_{g} S_{g} \overrightarrow{\vec{K}}_{i g} \bullet \vec{\nabla} C_{i g}\right)\right)\right]=q_{i}
\end{aligned}
$$

where $u_{j}$ is the phase advective flux given by the following multiphase version of Darcy's law:

$$
\begin{aligned}
& \overrightarrow{u_{j}}=-\frac{\overrightarrow{\vec{k}} k_{r j}}{\mu_{j}} \cdot\left(\vec{\nabla} P_{j}+\rho_{j} \vec{g}\right) \\
& \rho_{j}=\rho_{j}\left(T, P_{j}\right)
\end{aligned}
$$

and $q_{i}$ is a component source/sink term that accounts for the injection or extraction of component $i$.

The energy conservation equation is:

$$
\frac{\partial}{\partial t}\left[\phi\left(\rho_{w} S_{w} U_{w}+\rho_{g} S_{g} U_{g}\right)+(1-\phi) \rho_{s} U_{s}\right]+\vec{\nabla} \bullet\left(\rho_{w} \overrightarrow{u_{w}} H_{w}+\rho_{g} \overrightarrow{u_{g}} H_{g}-K_{T t} \vec{\nabla} T\right)=q_{E}
$$

where $q_{E}$ represents the energy source/sink term, the following phase internal energies are given by:

$$
U_{w}=\left(\sum_{i=1}^{N_{c}} C_{i w} U_{i w}\right) \quad U_{g}=\left(\sum_{i=1}^{N_{c}} C_{i g} U_{i g}\right) \quad U_{s}=\left(\sum_{i=1}^{N_{c}} C_{i s} U_{i s}\right)
$$


and the phase enthalpies are given by:

$$
H_{w^{\prime}}=\left(\sum_{i=1}^{N_{c}} C_{i w} H_{i w^{\prime}}\right) \quad \mathrm{H}_{g}=\left(\sum_{i=1}^{N_{c}} C_{i g} H_{i g}\right) \quad \mathrm{H}_{s}=\left(\sum_{i=1}^{N_{c}} C_{i s} H_{i s}\right)
$$

\subsubsection{Special Case of Wellbore Heat Exchanger}

In this wellbore heat exchanger model, the above general formulation in TETRAD takes the simplified form described in this section.

One molar conservation equation and one energy conservation equation exist for the single-phase liquid in the wellbore which consists of a single component. Both the liquid and vapor phases could be present in the formation, but since each phase contains only pure component, there would again be only a single molar conservation equation and energy conservation equation to solve for; thus, the wellbore heat exchanger model solves for one mass conservation and one energy conservation equation.

The mass conservation equation in the wellbore section is:

$\frac{\partial \rho_{w}}{\partial t}+\vec{\nabla} \bullet\left(\rho_{w} \overrightarrow{u_{w}}\right)=q_{w}$

The fluid circulation rate is maintained at a constant value specified as the following input data:

$\overrightarrow{u_{w Z}}=\frac{\dot{m_{i n}}}{\rho_{w} A}$

$\rho_{w}=\rho_{w}(T, P)$

where $q_{w}$ is a component source/sink term which is the input mass flux in the annulus and a sink term in the tubing.

The energy conservation equation in the wellbore section is:

$\frac{\partial}{\partial t}\left[\rho_{w} U_{w}\right]+\vec{\nabla} \cdot\left(\rho_{w} \overrightarrow{u_{w}} H_{w}-K_{T t} \vec{\nabla} T\right)=q_{E}$ the formation.

Similarly, the general mass conservation and energy equations would be simplified for

\subsection{Calibration of the Numerical Model}

\subsubsection{Validation Case Description}

A preliminary study was conducted at SNL using their wellbore simulator GEOTEMP (Mondy and Duda, 1984). We elected to extend that study using the TETRAD simulator (Vinsome and Shook 1993). The reasons we chose the TETRAD simulator are as follows: 
- $\quad$ GEOTEMP has static fluid in the formation, while in TETRAD the fluid in formation, in a few case studies, is allowed to undergo natural convection and change in phases.

- The gridding in the radial direction increases exponentially in GEOTEMP, while in TETRAD, individual grid dimensioning is allowed; hence, a variable radial gridding scheme was used to model the various elements with varying thickness, different physical and thermal properties in the wellbore heat exchanger.

- TETRAD allowed us to define various boundary conditions such as the heat loss at the surface, basal heat flux, and a no-flow/pressure boundary at the edges.

- TETRAD has many numerical controls that facilitate a smooth convergence of the Newtonian iterations.

- TETRAD has many output options that provide a better estimate of the fluid temperature profiles, histories, and fluid velocities etc.

We first ran an adequate set of validation cases, and compared TETRAD and GEOTEMP results. We then conducted the sensitivity case study using TETRAD. Details of the validation exercise are described in the remainder of this section.

The wellbore used in our calibration study had an outside diameter of $244.5 \mathrm{~mm}$ (9.625 in.) and was $1,828.8 \mathrm{~m}(6,000 \mathrm{ft})$ deep, with $762.0 \mathrm{~m}(2,500 \mathrm{ft})$ cemented and cased. The insulated tubing had an outside diameter of $91.44 \mathrm{~mm}$ ( $3.6 \mathrm{in}$.) and was $7.62 \mathrm{~mm}(0.3 \mathrm{in}$.) thick. The cemented casing thickness was $13.97-\mathrm{mm}\left(0.55\right.$-in.). The bilinear temperature profile assigned to the wellbore formation was $26.7^{\circ} \mathrm{C}$ $\left(80^{\circ} \mathrm{F}\right)$ at the surface, $121.11^{\circ} \mathrm{C}\left(250^{\circ} \mathrm{F}\right)$ at the $609.6-\mathrm{m}(2,000-\mathrm{ft})$ depth, and $176.67^{\circ} \mathrm{C}\left(350^{\circ} \mathrm{F}\right)$ at the $1,828.8-\mathrm{m}(6,000-\mathrm{ft})$ depth. The fluid injected into the annulus was $26.7^{\circ} \mathrm{C}\left(80^{\circ} \mathrm{F}\right)$, and the hot fluid was produced from the tubing. Fluid return temperatures were compared for both $20 \mathrm{gpm}(1.26 \mathrm{~kg} / \mathrm{s})$ and $100 \mathrm{gpm}(6.3 \mathrm{~kg} / \mathrm{s})$ circulation rates. Table 1 gives the thermal properties used for this model. Injection of fluid was treated as mass influx and production was treated as a sink term.

Table 1. Thermal properties used for the calibration study case.

\begin{tabular}{|l|c|c|}
\hline & $\begin{array}{c}\text { Thermal Conductivity } \\
\left(\mathrm{W} / \mathrm{m}^{\circ} \mathrm{C}\right)\end{array}$ & $\begin{array}{c}\text { Volumetric Heat Capacity } \\
\left(\mathrm{kJ} / \mathrm{m}^{3 \circ} \mathrm{C}\right)\end{array}$ \\
\hline Insulated tubing & 3.46 & $3,614.86$ \\
\hline Cement & 0.87 & $1,394.97$ \\
\hline Casing & 45.35 & $3,614.86$ \\
\hline Working fluid (water) & 0.69 & $4,186.80$ \\
\hline Formation & 3.46 & $2,816.77$ \\
\hline
\end{tabular}

\subsubsection{Comparison Results}

We calibrated the TETRAD model with the GEOTEMP model using the input for the SNL case to quantify differences in predicted performance. As can be seen in Figure 3, a good agreement exists between the $20 \mathrm{gpm}(1.26 \mathrm{~kg} / \mathrm{s})$ circulation rate and the $100 \mathrm{gpm}(6.3 \mathrm{~kg} / \mathrm{s})$ circulation rate where, despite some differences in the transient stage, over long periods the solutions come closer to being equal. When production is initiated, the fluid at the bottom of the hole rises up through the tubing. 


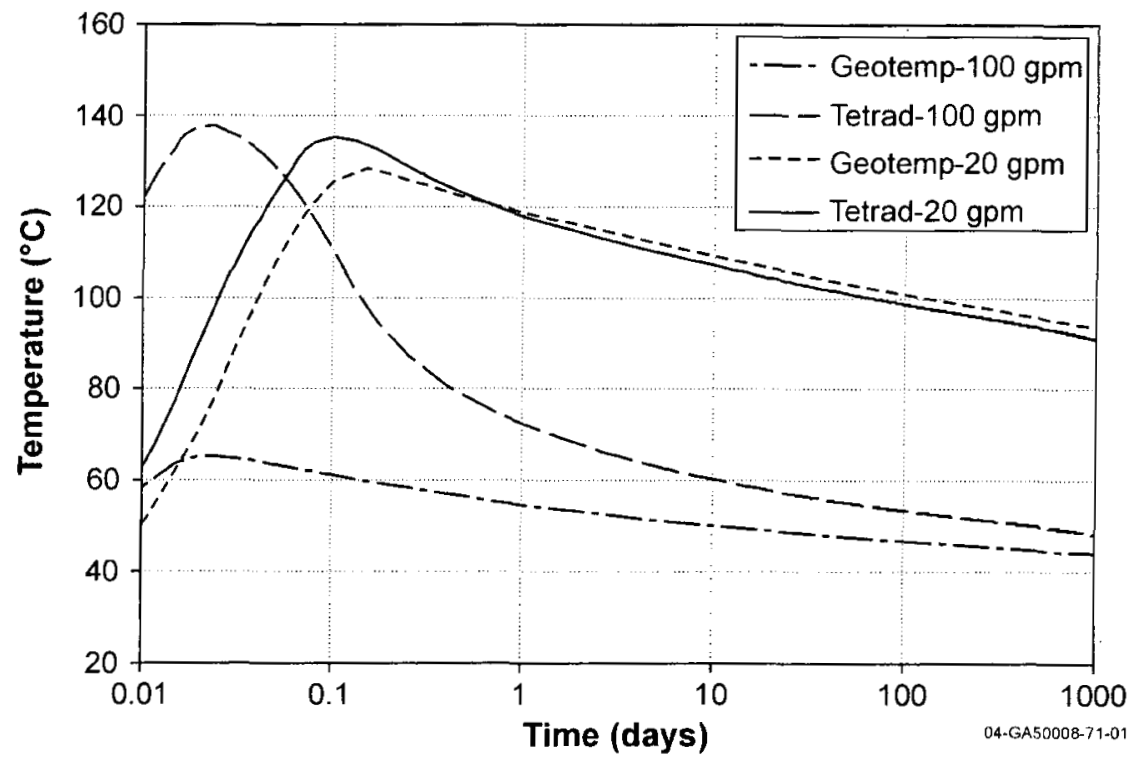

Figure 3. Comparison of the produced fluid temperature histories from TETRAD and GEOTEMP at 100 and $20 \mathrm{gpm}$ circulation rates, showing the convergence at later time.

If there were no fluid mixing and perfect insulation, we would expect the maximum peak fluid return temperature to be the same as the bottomhole fluid temperature of $176.7^{\circ} \mathrm{C}\left(350^{\circ} \mathrm{F}\right)$. At $100 \mathrm{gpm}(6.3$ $\mathrm{kg} / \mathrm{s})$ and $20 \mathrm{gpm}(1.26 \mathrm{~kg} / \mathrm{s})$ circulation rates, the fluid residence time in tubing was calculated to be 0.015 and 0.075 day, respectively. For the $100 \mathrm{gpm}(6.3 \mathrm{~kg} / \mathrm{s})$ circulation rate, TETRAD gives a peak temperature of $137.8^{\circ} \mathrm{C}\left(280^{\circ} \mathrm{F}\right)$ at 0.019 day, while GEOTEMP gives a peak temperature of $65.1^{\circ} \mathrm{C}$ $\left(149^{\circ} \mathrm{F}\right)$ at 0.025 day. For the $20 \mathrm{gpm}(1.26 \mathrm{~kg} / \mathrm{s})$ circulation rate, TETRAD gives a peak temperature of $135.3^{\circ} \mathrm{C}\left(276^{\circ} \mathrm{F}\right)$ at 0.1 day, while GEOTEMP gives a peak temperature of $128.3^{\circ} \mathrm{C}\left(263^{\circ} \mathrm{F}\right)$ at 0.15 day. TETRAD calculated the peak fluid returns temperature and time of peak temperature closer to the bottom fluid temperature and the tubing fluid residence time ("bottoms up" time), respectively. This intuitively indicates that TETRAD credibly represented the flow in the tubing. This comparison of simulations does not necessarily mean the results are accurate, but disagreement would identify an issue of concern.

\subsection{Grid Refinement Study}

Figure 4 shows the areal grid refinement employed in the numerical model. The areal gridding was varied from 19 to 23 and to 29 cells, at which a convergent solution was obtained. Figure 5 shows the areal grid refinement plot. Similarly, a vertical grid refinement was done and a cell height of $30.5 \mathrm{~m}$ (100 $\mathrm{ft}$ ) led to a convergent solution. Figure 6 shows the vertical grid refinement plot. 


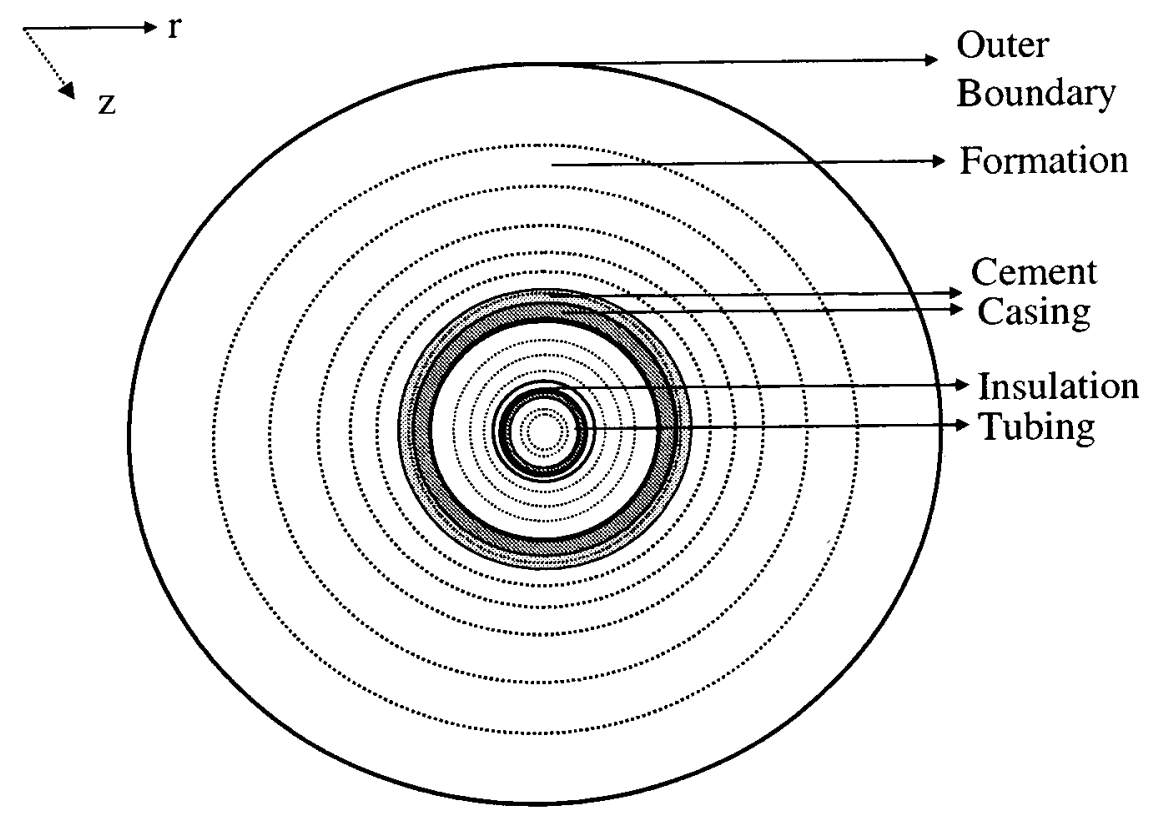

Figure 4. Schematic diagram of the areal gridding used in the numerical model.

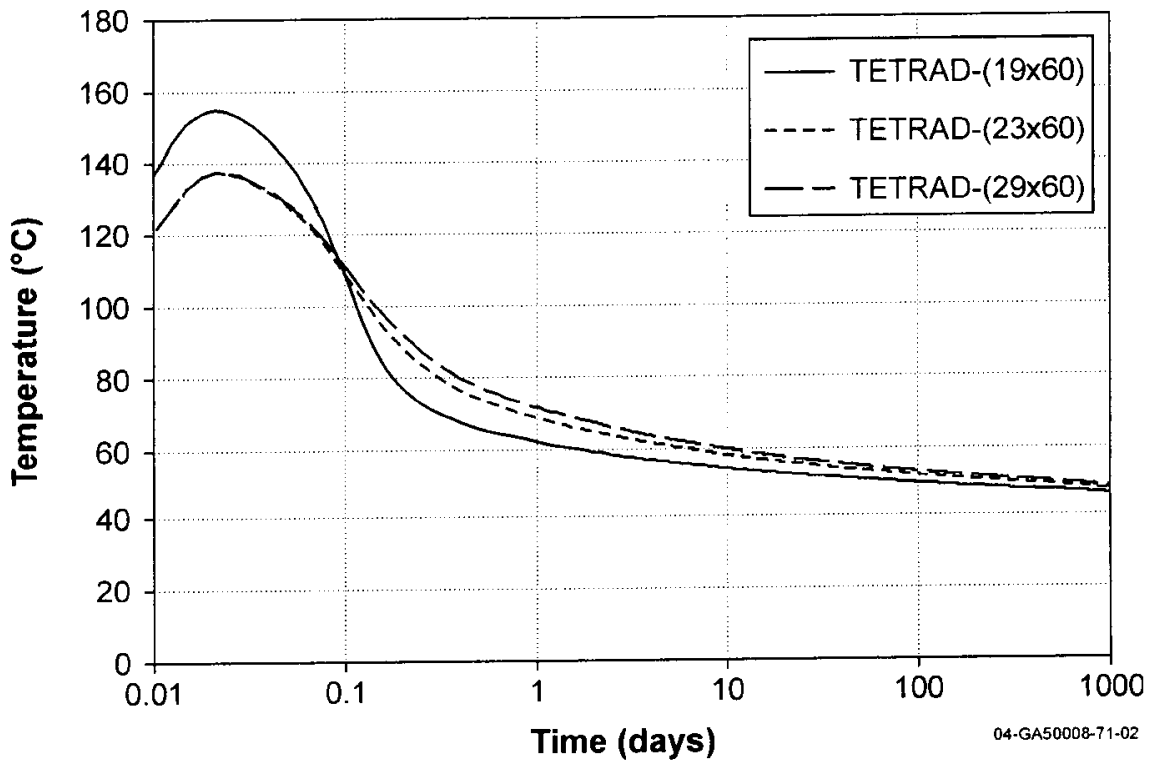

Figure 5. Areal grid refinement plot showing converged solution for 29 grids. 


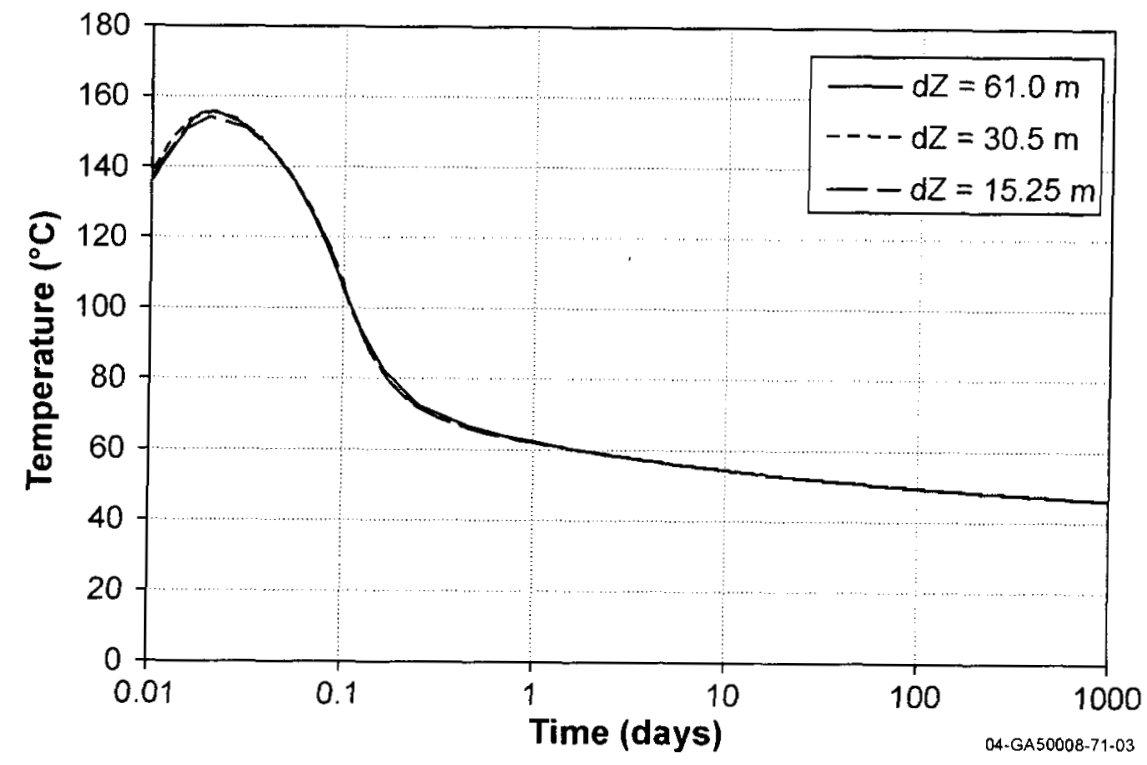

Figure 6. Vertical grid refinement showing converged solution at grid block size of $30.5 \mathrm{~m}$. 


\section{BASE CASE}

\subsection{Case Description}

We developed a computer simulation model that we felt accurately represented the well, casing, and tubing configurations that would be used in a wellbore heat exchanger type of application as a base case for the sensitivity study. The most notable differences between the calibration case and the base case were the properties of the formation type used - the bottomhole temperature and the wellbore diameter. The base case consisted of a $311 \mathrm{~mm}$ (12.25 in.) diameter well drilled vertically to 5,593 $\mathrm{m}(18,350 \mathrm{ft})$. The top $762 \mathrm{~m}(2,500 \mathrm{ft})$ of the well was cased and cemented; the balance of the well was an open hole. Tubing extended to the bottom of the wellbore. The tubing was $6.35 \mathrm{~mm}(0.25 \mathrm{in}$.) thick with an internal diameter of $76 \mathrm{~mm}$ ( $3 \mathrm{in}$.), and was covered by $6.35 \mathrm{~mm}(0.25 \mathrm{in}$.) of insulation. The tubing and casing were made of steel, the insulation of magnesia (the formation has properties typical of sandstone), and water was used. The well depth was calculated assuming a surface temperature of $26.7^{\circ} \mathrm{C}\left(80^{\circ} \mathrm{F}\right)$, a bottomhole temperature of $350^{\circ} \mathrm{C}\left(662^{\circ} \mathrm{F}\right)$, a basal heat flux of $0.1 \mathrm{~W} / \mathrm{m}^{2}\left(0.0317 \mathrm{BTU} / \mathrm{ft}^{2} . \mathrm{h}\right)$, and a uniform formation effective thermal conductivity of $1.73 \mathrm{~W} / \mathrm{m}^{\circ} \mathrm{C}\left(0.9996 \mathrm{BTU} / \mathrm{ft} . \mathrm{h} .{ }^{\circ} \mathrm{F}\right)$. The properties selected for the base case were considered representative of geothermal drilling and completion operations (Lide 1993; Prats 1986), but varied in subsequent sensitivity studies. The base case properties are summarized in Table 2 . The base case wellbore geometry is plotted to scale in Figure 7.

The wellbore was filled with water, which was in thermal equilibrium with the formation. At $t=0$ a constant volumetric rate of $100 \mathrm{gpm}(6.3 \mathrm{~kg} / \mathrm{s})$ was injected in the annulus and fluids were produced from the tubing. The simulation time period was selected as 5 years $(1,826$ days $)$.

Table 2. Base case description.

\begin{tabular}{|l|l|}
\hline \multicolumn{1}{|c|}{ Well Geometry } & \multicolumn{1}{c|}{ Parameters } \\
\hline Tubing inner diameter $-76.2 \mathrm{~mm}$ & Basal heat flux $-0.1 \mathrm{~W} / \mathrm{m}^{2}$ \\
\hline Tubing outer diameter $-88.9 \mathrm{~mm}$ & Formation thermal conductivity $-1.73 \mathrm{~W} / \mathrm{m}^{\circ} \mathrm{C}$ \\
\hline Insulation outer diameter $-101.6 \mathrm{~mm}$ & Formation volumetric heat capacity $-1,810.7 \mathrm{~kJ} / \mathrm{m}^{3 \circ} \mathrm{C}$ \\
\hline Casing inner diameter $-228.6 \mathrm{~mm}$ & Insulation thermal conductivity $-0.07 \mathrm{~W} / \mathrm{m}^{\circ} \mathrm{C}$ \\
\hline Casing outer diameter $-244.475 \mathrm{~mm}$ & Insulation volumetric heat capacity $-7,608.4 \mathrm{~kJ} / \mathrm{m}^{3 \circ} \mathrm{C}$ \\
\hline Wellbore diameter $-311 \mathrm{~mm}$ & $\begin{array}{l}\text { Tubing and casing (steel) thermal conductivity }- \\
44.83 \mathrm{~W} / \mathrm{m}^{\circ} \mathrm{C}\end{array}$ \\
\hline Well depth $-5,593 \mathrm{~m}$ & $\begin{array}{l}\text { Tubing and casing (steel) volumetric heat capacity }- \\
3,836.93 \mathrm{~kJ} / \mathrm{m}^{3 \circ} \mathrm{C}\end{array}$ \\
\hline & Cement thermal conductivity $-0.87 \mathrm{~W} / \mathrm{m}^{\circ} \mathrm{C}$ \\
\hline & Cement volumetric heat capacity $-1,260.80 \mathrm{~kJ} / \mathrm{m}^{3 \circ} \mathrm{C}$ \\
\hline & $\begin{array}{l}\text { Working fluid volumetric heat capacity }- \\
4,186.8 \mathrm{~kJ} / \mathrm{m}^{3}{ }^{\circ} \mathrm{C}\end{array}$ \\
\hline & $\vdots$ \\
\hline & Circulation rate -100 gpm \\
\hline & Surface temperature $-26.7^{\circ} \mathrm{C}$ \\
\hline & Bottomhole temperature $-350^{\circ} \mathrm{C}$ \\
\hline
\end{tabular}




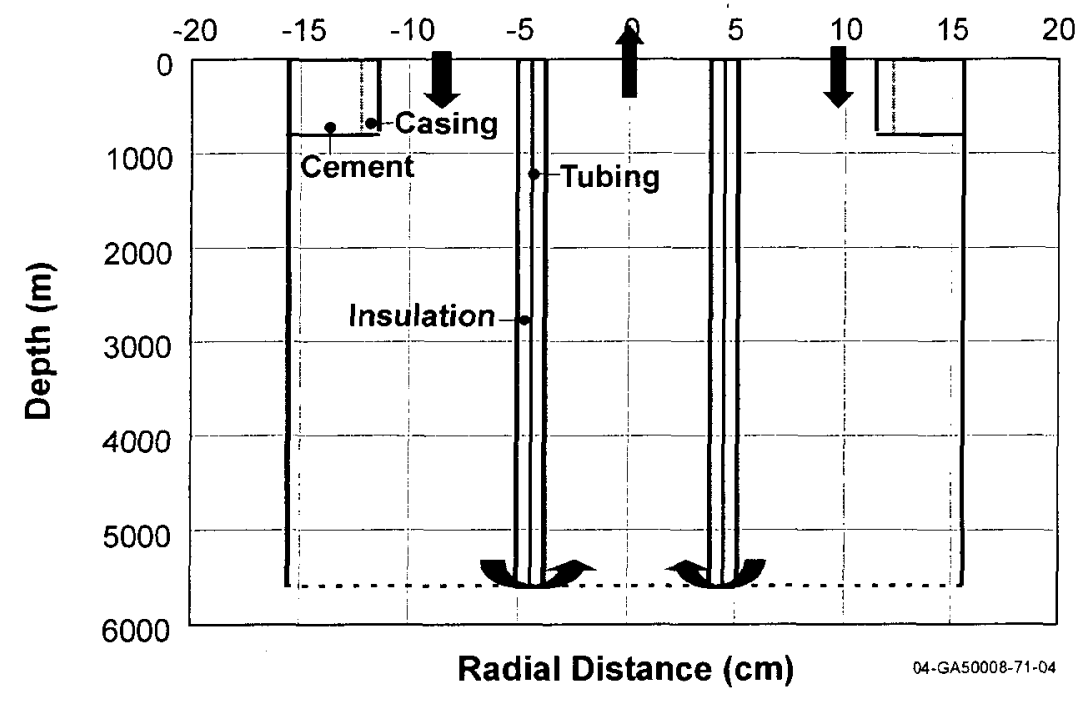

Figure 7. Diagram describing the wellbore geometry of the base case (to scale).

The thermal resistance offered by tubing and insulation helped in preserving the thermal energy content in the fluid, while the thermal resistance offered by the casing and cement hindered the thermal energy flow from the formation to the fluid. Although a lumped parameter approach was not taken in this study, an effective heat transfer coefficient for the cased vs. uncased portion of the well was determined as described in Appendix A. The overall heat transfer coefficient for the base case was $10.26 \mathrm{~W} / \mathrm{m}^{2 \circ} \mathrm{C}$ (1.807 BTU/ft $\left.{ }^{2} . h .{ }^{\circ} \mathrm{F}\right)$ for the cased portion of the well and $11.74 \mathrm{~W} / \mathrm{m}^{2 \circ} \mathrm{C}\left(2.068 \mathrm{BTU} / \mathrm{ft}^{2} . \mathrm{h} .{ }^{\circ} \mathrm{F}\right)$ for the open portion. The base case input data file is included in Appendix B.

\subsection{Reported Output Variables}

The results analyzed and reported are the produced fluid temperature and ideal work extraction rate. The second law of thermodynamics allows one to quantify the limit placed on the conversion of heat to work through the definition of ideal energy. Ideal energy is that portion of energy that could be converted into work by ideal processes, which bring the energy source to a dead state-a state in equilibrium with the earth and its atmosphere. Ideal work was calculated from the produced liquid enthalpy and entropy at wellhead conditions, and ambient conditions of $26.7^{\circ} \mathrm{C}\left(80^{\circ} \mathrm{F}\right)$ and $1.0 \mathrm{~atm}(14.7$ psi). This available energy or ideal work rate represents the maximum power that an energy conversion system could produce when using an energy source (geothermal) to generate electricity. We discuss realistic conversion efficiency using the optimum parameters in Section 7.

\subsection{Results}

Figure 8 illustrates the produced fluid temperature history for the base case. A maximum produced temperature of $253^{\circ} \mathrm{C}\left(487.4^{\circ} \mathrm{F}\right)$ is observed at approximately 0.1 days (well bottom fluid produced at the surface). The temperature falls quickly, and enters a pseudosteady-state (PSS) behavior at about 500 days. We define PSS as the period wherein the temperature decline is linear and small. Figures 9 and 10 plot the temperature profile in the radial direction at 5 days and 500 days at depths of $351 \mathrm{~m}(1,152 \mathrm{ft}), 3,033 \mathrm{~m}$ $(9,951 \mathrm{ft})$ and $4,557 \mathrm{~m}(14,951 \mathrm{ft})$ below land surface. At the onset of PSS, the effluent temperature ( $\left.\mathrm{T}_{\mathrm{PSS}}\right)$ is approximately $84^{\circ} \mathrm{C}\left(183^{\circ} \mathrm{F}\right)$, and declining at $0.006^{\circ} \mathrm{C} /$ day $\left(0.0108^{\circ} \mathrm{F} /\right.$ day $)$. Figure 11 shows the ideal 
work extraction rate history plot. At PSS, ideal work is $129 \mathrm{~kW}(440.2 \mathrm{e}+3 \mathrm{BTU} / \mathrm{h})$, and is declining by approximately $22 \mathrm{~W} /$ day (75.07 BTU/h/day).

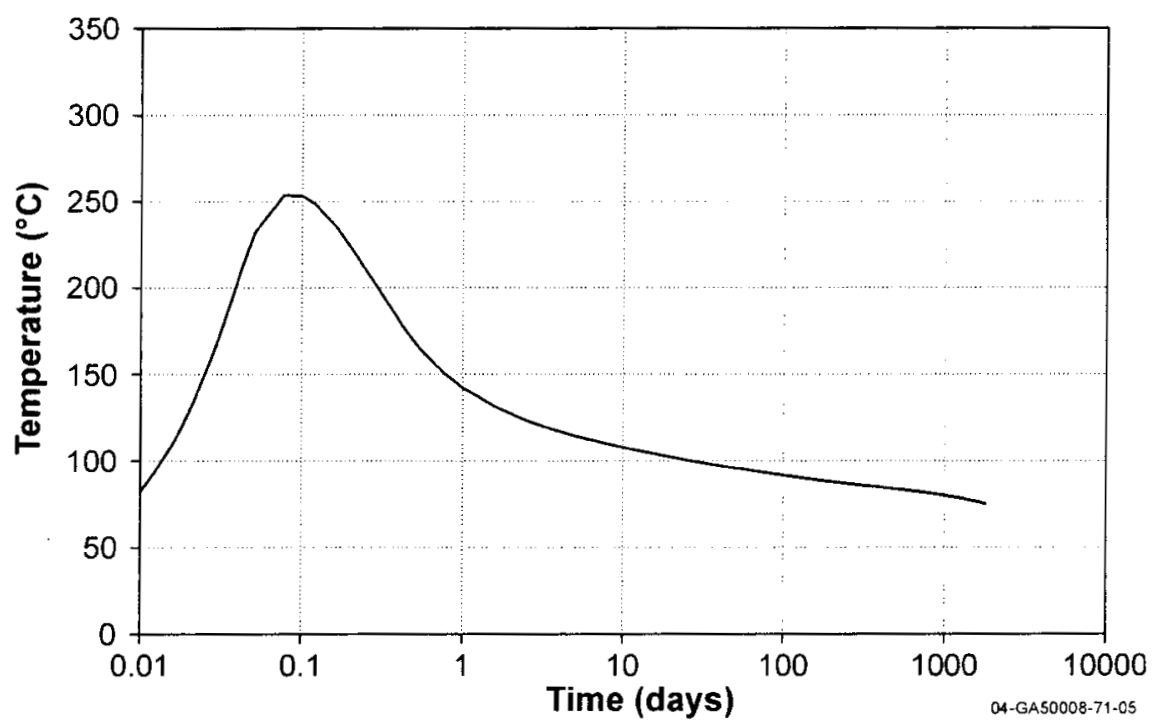

Figure 8. Produced fluid temperature history for the base case

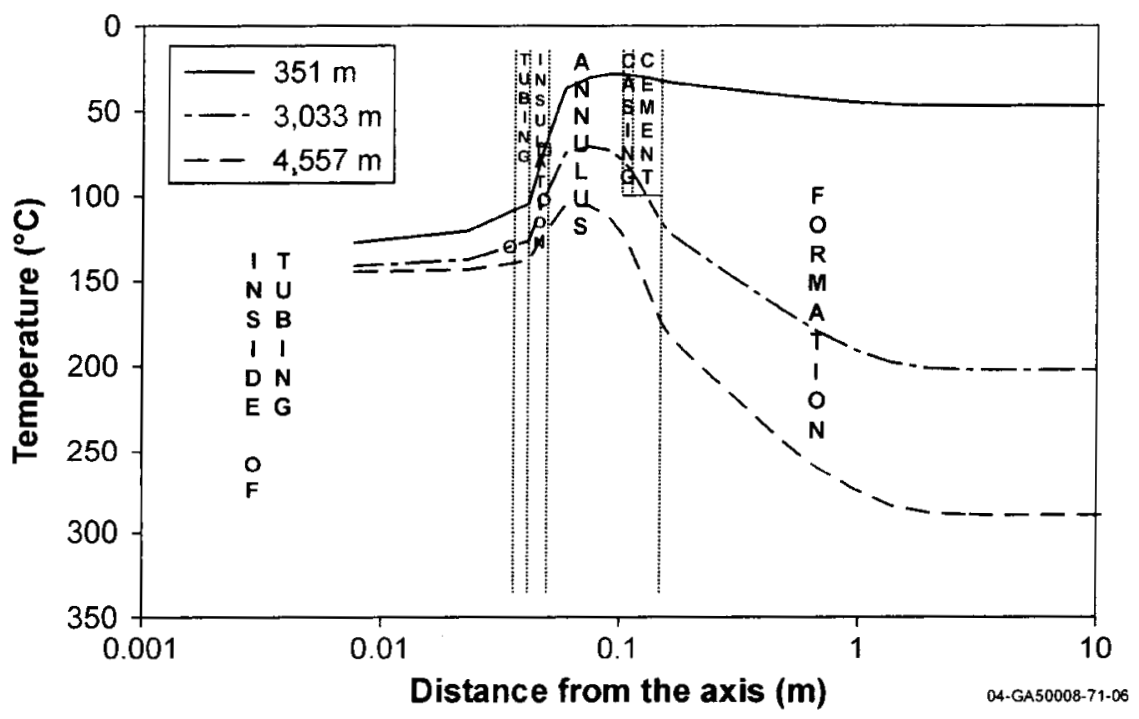

Figure 9. Temperature profile in the radial direction in the wellbore and formation at three depths below land surface and at 5 days. 


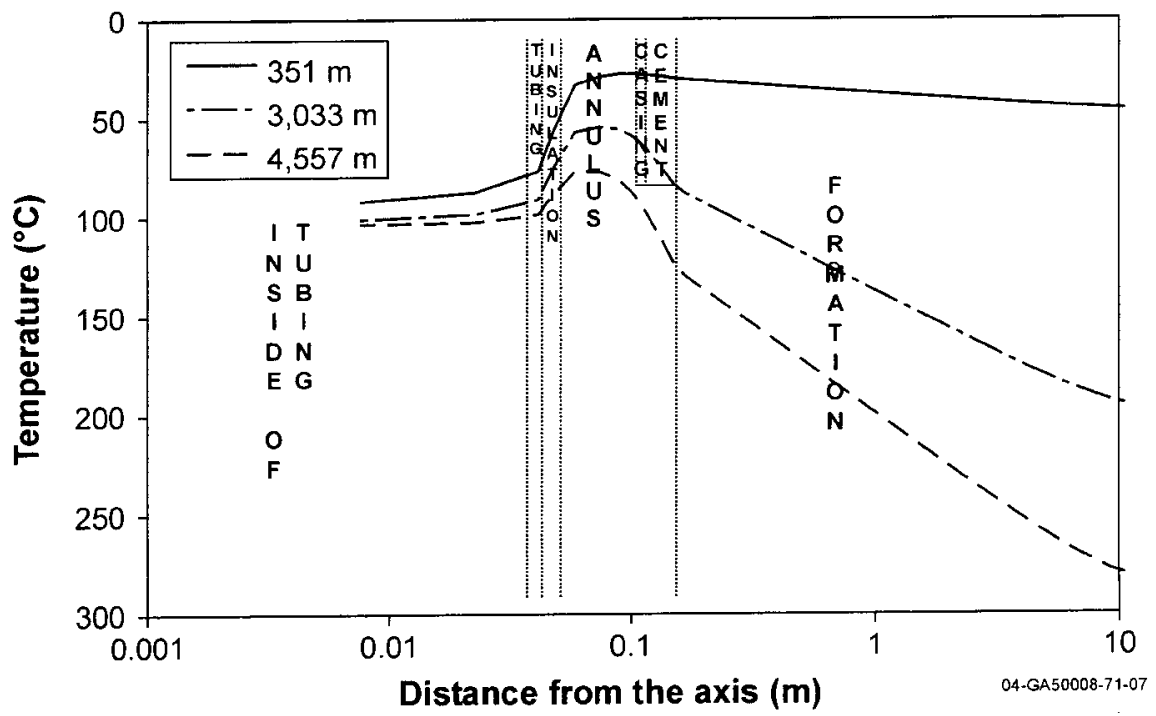

Figure 10. Temperature profile in the radial direction in the wellbore and formation at three depths below land surface and at 500 days (onset of PSS).

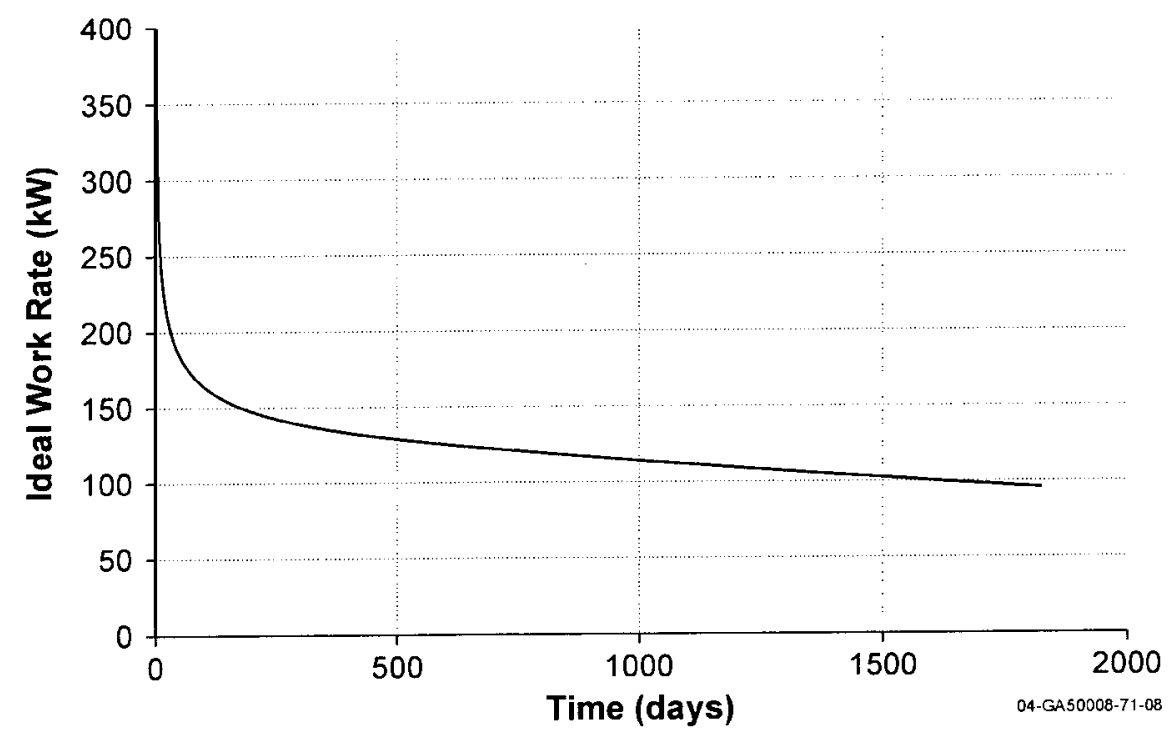

Figure 11. Ideal work extraction rate history plot for the base case. 


\section{PARAMETRIC SENSITIVITY STUDY}

From the base case model described above, we performed a comprehensive sensitivity study of formation properties and operational variables, and how they affect effluent temperature and ideal work histories. This study included an analysis of the wellbore geometry, working fluid properties, circulation rate, and regional properties of heat flux, formation rock type, and natural convection effects. The range over which variables were perturbed are summarized in Table 3. A description of the data used for the sensitivity study cases is given in Table 4.

Table 3. Sensitivity study parameters and ranges of the analysis.

\begin{tabular}{|c|c|}
\hline Parameter & Range \\
\hline Circulation rate & 20,100 and $500 \mathrm{gpm}$ \\
\hline Wellbore diameter & 311 and $660.4 \mathrm{~mm}$ \\
\hline Casing length & 1524,3048 and $4572 \mathrm{~m}$ \\
\hline Tubing insulation thermal conductivity & $0.07,0.007$ and $0.0 \mathrm{~W} / \mathrm{m}^{\circ} \mathrm{C}$ \\
\hline Tubing outer diameter & 88.9 and $127 \mathrm{~mm}$ \\
\hline Working fluid volumetric heat capacity & $2093,4186,8374$ and $41868 \mathrm{~kJ} / \mathrm{m}^{3 \circ} \mathrm{C}$ \\
\hline Basal heat flux & $0.1,0.2$ and $0.5 \mathrm{~W} / \mathrm{m}^{2}$ \\
\hline $\begin{array}{l}\text { Formation thermal properties: } \\
\mathrm{K} / \mathrm{V}_{\kappa} \text { (or, more appropriately, ranges of thermal } \\
\text { conductivity and diffusivity representative of } \\
\text { most rock types) }\end{array}$ & 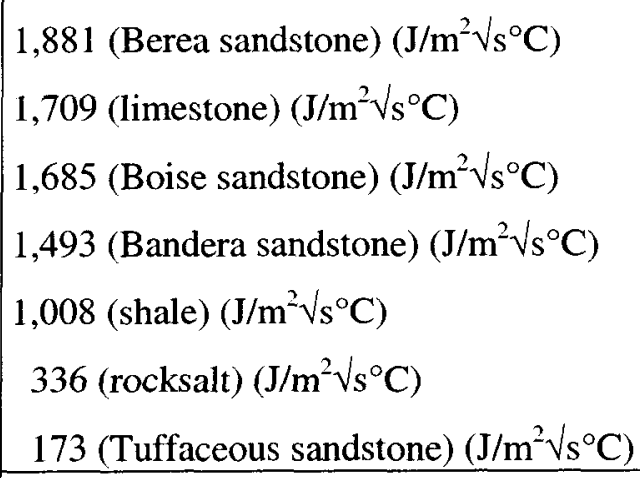 \\
\hline $\begin{array}{l}\text { Natural convection effects (vertical interstitial } \\
\text { velocity) }\end{array}$ & $0.3 \mathrm{~m} /$ day \\
\hline
\end{tabular}


Table 4. Data summary for the sensitivity study cases.

\begin{tabular}{|c|c|c|c|c|c|c|c|c|c|c|}
\hline $\begin{array}{c}\text { Sensitivity } \\
\text { Study Variable }\end{array}$ & $\begin{array}{l}\text { Circulation } \\
\text { Rate } \\
\text { (gpm) }\end{array}$ & $\begin{array}{c}\text { Well Diameter } \\
(\mathrm{mm})\end{array}$ & $\begin{array}{l}\text { Well Depth } \\
\text { (m) }\end{array}$ & $\begin{array}{l}\text { Casing Length } \\
\text { (m) }\end{array}$ & $\begin{array}{l}\text { Tubing Outer } \\
\text { Diameter } \\
\text { (mm.) }\end{array}$ & $\begin{array}{c}\text { Formation } \\
\text { Thermal Conductivity } \\
\left(\mathrm{W} / \mathrm{m}^{\circ} \mathrm{C}\right)\end{array}$ & $\begin{array}{c}\text { Formation } \\
\text { Volumetric } \\
\text { Heat } \\
\text { Capacity } \\
\left(\mathrm{kJ} / \mathrm{m}^{3 \circ} \mathrm{C}\right)\end{array}$ & $\begin{array}{l}\text { Working Fluid } \\
\text { Volumetric } \\
\text { Heat Capacity } \\
\left(\mathrm{kJ} / \mathrm{m}^{30} \mathrm{C}\right)\end{array}$ & $\begin{array}{l}\text { Insulation } \\
\text { Thermal } \\
\text { Conductivity } \\
\left(\mathrm{W} / \mathrm{m}^{\circ} \mathrm{C}\right)\end{array}$ & $\begin{array}{l}\text { Working Fluid } \\
\text { Inlet } \\
\text { Temperature } \\
\left({ }^{\circ} \mathrm{C}\right)\end{array}$ \\
\hline $\begin{array}{l}\text { Circulation } \\
\text { Rates }\end{array}$ & $\begin{array}{l}\text { (i) } 20.0 \\
\text { (ii) } 100.0 \\
\text { (iii) } 500.0\end{array}$ & $\cdot 311.0$ & $5,593.1$ & $1,524.0$ & 88.9 & 1.73 & 1810.7 & $4,186.8$ & 0.07 & 26.7 \\
\hline $\begin{array}{l}\text { Wellbore } \\
\text { Diameters }\end{array}$ & 100.0 & $\begin{array}{l}311.0 \\
660.4\end{array}$ & $5,593.1$ & $1,524.0$ & 88.9 & 1.73 & $1,810.7$ & $4,186.8$ & 0.07 & 26.7 \\
\hline Casing Length & 100.0 & 311.0 & $5,593.1$ & $\begin{array}{l}\text { (i) } 1,524.0 \\
\text { (ii) } 3,048.0 \\
\text { (iii) } 4,572.0\end{array}$ & 88.9 & 1.73 & 1.810 .7 & $4,186.8$ & 0.07 & 26.7 \\
\hline $\begin{array}{l}\text { Tubing } \\
\text { Properties }\end{array}$ & 100.0 & 311.0 & 5.593 .1 & 1.524 .0 & $\begin{array}{l}\text { (i) } 88.9 \\
\text { (ii) } 127.0\end{array}$ & 1.73 & $1,810.7$ & $4,186.8$ & $\begin{array}{l}\text { (1) } 0.07 \\
\text { (3) } 0.0\end{array}$ & 26.7 \\
\hline $\begin{array}{l}\text { Working Fluid } \\
\text { Properties }\end{array}$ & 100.0 & 311.0 & $5,593.1$ & $1,524.0$ & 88.9 & 1.73 & $1,810.7$ & $\begin{array}{l}\text { (i) } 2,093.4 \\
\text { (ii) } 4,186.8 \\
\text { (iii) } 8,373.6 \\
\text { (iv) } 41,868.0\end{array}$ & 0.07 & 26.7 \\
\hline $\begin{array}{l}\text { Basal Heat } \\
\text { Flux }\end{array}$ & 100.0 & 311.0 & $\begin{array}{l}\text { (i) } 5,593.1 \\
\left.\text { (0.1 W/m } 2 \mathrm{~m}^{2}\right) \\
\text { (ii) } 2,796.5 \\
\left(0.2 \mathrm{~W} / \mathrm{m}^{2}\right) \\
\text { (iii) } 1,118.6 \\
\left(0.5 \mathrm{~W} / \mathrm{m}^{2}\right)\end{array}$ & $1,524.0$ & 88.9 & 1.73 & $1,810.7$ & $4,186.8$ & 0.07 & 26.7 \\
\hline $\begin{array}{l}\text { Formation } \\
\text { Thermal } \\
\text { Properties }\end{array}$ & 100.0 & 311.0 & $5,593.1$ & $1,524.0$ & 88.9 & $\begin{array}{l}\text { (i) } 1.57 \text { (Berea SS) } \\
\text { (ii) } 1.56 \text { (Limestone) } \\
\text { (iii) } 1.41 \text { (Boise SS) } \\
\text { (iv) } 0.16 \text { (Bandera SS) } \\
\text { (v) } 1.89 \text { (Shale) } \\
\text { (vi) } 0.60 \text { (Rock Salt) } \\
\text { (vii) } 0.69 \text { (Tuffaceous) }\end{array}$ & $\begin{array}{l}\text { (1) } 1,810.73 \\
\text { (2) } 1,877.79 \\
\text { (3) } 1,576.00 \\
\text { (4) } 181.07 \\
\text { (5) } 1,875.67 \\
\text { (6) } 188.32 \\
\text { (7) } 1,469.17\end{array}$ & $4,186.8$ & 0.07 & 26.7 \\
\hline $\begin{array}{l}\text { Natural } \\
\text { Convection } \\
\text { Effects }\end{array}$ & 100.0 & 311.0 & $5,593.1$ & $1,524.0$ & 88.9 & 1.73 & $1,810.7$ & $4,186.6$ & 0.07 & 26.7 \\
\hline
\end{tabular}




\subsection{Circulation Rates}

We conducted numerical investigations to study the effects of three different circulation rates$20 \mathrm{gpm}(1.26 \mathrm{~kg} / \mathrm{s}), 100 \mathrm{gpm}(6.3 \mathrm{~kg} / \mathrm{s})$, and $500 \mathrm{gpm}(31.5 \mathrm{~kg} / \mathrm{s}) \longrightarrow$-on the produced fluid temperature and ideal work extraction rates. The fluid return temperature histories for the three circulation rates are shown in Figure 12. Pseudosteady-state temperatures ranged from $40-125^{\circ} \mathrm{C}\left(104-257^{\circ} \mathrm{F}\right)$. An increase in circulation rate by 5 times, from $20 \mathrm{gpm}(1.26 \mathrm{~kg} / \mathrm{s})$ to $100 \mathrm{gpm}(6.3 \mathrm{~kg} / \mathrm{s})$ to $500 \mathrm{gpm}(31.5 \mathrm{~kg} / \mathrm{s})$, led to a decrease in temperature from $123^{\circ} \mathrm{C}\left(253^{\circ} \mathrm{F}\right)$ to $84^{\circ} \mathrm{C}\left(183^{\circ} \mathrm{F}\right)$ and to $40^{\circ} \mathrm{C}\left(104^{\circ} \mathrm{F}\right)$, respectively, at 500 days (onset of the PSS condition). There was an absolute percentage loss in temperature of $32 \%$ when the circulation rate was increased from $20 \mathrm{gpm}(1.26 \mathrm{~kg} / \mathrm{s})$ to $100 \mathrm{gpm}(6.3 \mathrm{~kg} / \mathrm{s})$, and a temperature loss of $51 \%$ when the circulation rate was increased from $100 \mathrm{gpm}(6.3 \mathrm{~kg} / \mathrm{s})$ to $500 \mathrm{gpm}(31.5 \mathrm{~kg} / \mathrm{s})$ at the onset of PSS. Reductions in the maximum temperature observed are due to increased mixing at lower injection rates. The total fluid residence times in the wellbore for $500 \mathrm{gpm}(31.5 \mathrm{~kg} / \mathrm{s}), 100 \mathrm{gpm}(6.3 \mathrm{~kg} / \mathrm{s})$, and $20 \mathrm{gpm}(1.26 \mathrm{~kg} / \mathrm{s})$ were $0.14,0.70$, and 3.48 days, respectively. Owing to its small residence time of 0.14 day, the $500 \mathrm{gpm}(31.5 \mathrm{~kg} / \mathrm{s})$ circulation rate could not obtain heat fast enough. Variations in effluent temperature are due to the fluid residence time-the larger the residence time, the higher the produced temperature. This can be misleading, however, as is discussed in the following paragraph.

Figure 13 shows the ideal work extraction rate history for the three circulation rates. The PSS ideal work extraction rates are $68 \mathrm{~kW}(232.0 \mathrm{e}+3 \mathrm{BTU} / \mathrm{h}), 129 \mathrm{~kW}(440.2 \mathrm{e}+3 \mathrm{BTU} / \mathrm{h})$, and $45 \mathrm{~kW}(153.5 \mathrm{e}+3$ $\mathrm{BTU} / \mathrm{h})$ for $20 \mathrm{gpm}(1.26 \mathrm{~kg} / \mathrm{s}), 100 \mathrm{gpm}(6.3 \mathrm{~kg} / \mathrm{s})$, and $500 \mathrm{gpm}(31.5 \mathrm{~kg} / \mathrm{s})$, respectively. Ideal work is a function of both effluent temperature and circulation rate. These work to offset one another, so there is an optimum circulation rate that balances the adverse effects of high effluent temperatures at low circulation rates with low effluent temperatures at high rates. Conversion of the high effluent temperature of $123^{\circ} \mathrm{C}\left(253^{\circ} \mathrm{F}\right)$ into ideal work rate was low because of the low circulation rate of $20 \mathrm{gpm}(1.26 \mathrm{~kg} / \mathrm{s})$. Similarly, utilization of the thermal energy output at $500 \mathrm{gpm}$ is low because of the low fluid output temperature of $40^{\circ} \mathrm{C}\left(104^{\circ} \mathrm{F}\right)$. Figure 14 is a plot of the produced fluid temperatures and ideal work as a function of circulation rates at PSS. This plot shows that the optimal circulation rate among the three cases studied was $100 \mathrm{gpm}(6.3 \mathrm{~kg} / \mathrm{s})$ since the ideal work extraction rate is a maximum.

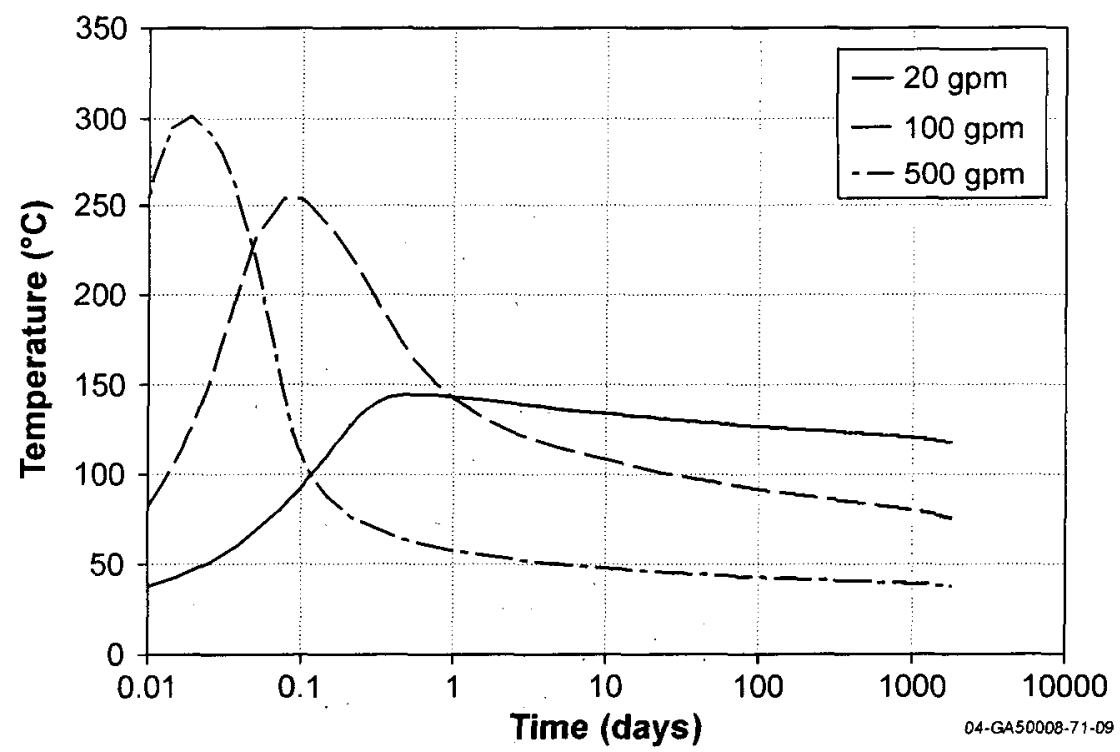

Figure 12. Fluid return temperature history for circulation rates of 20,100 , and $500 \mathrm{gpm}$ showing the highest PSS return temperature for the 20 gpm case. 


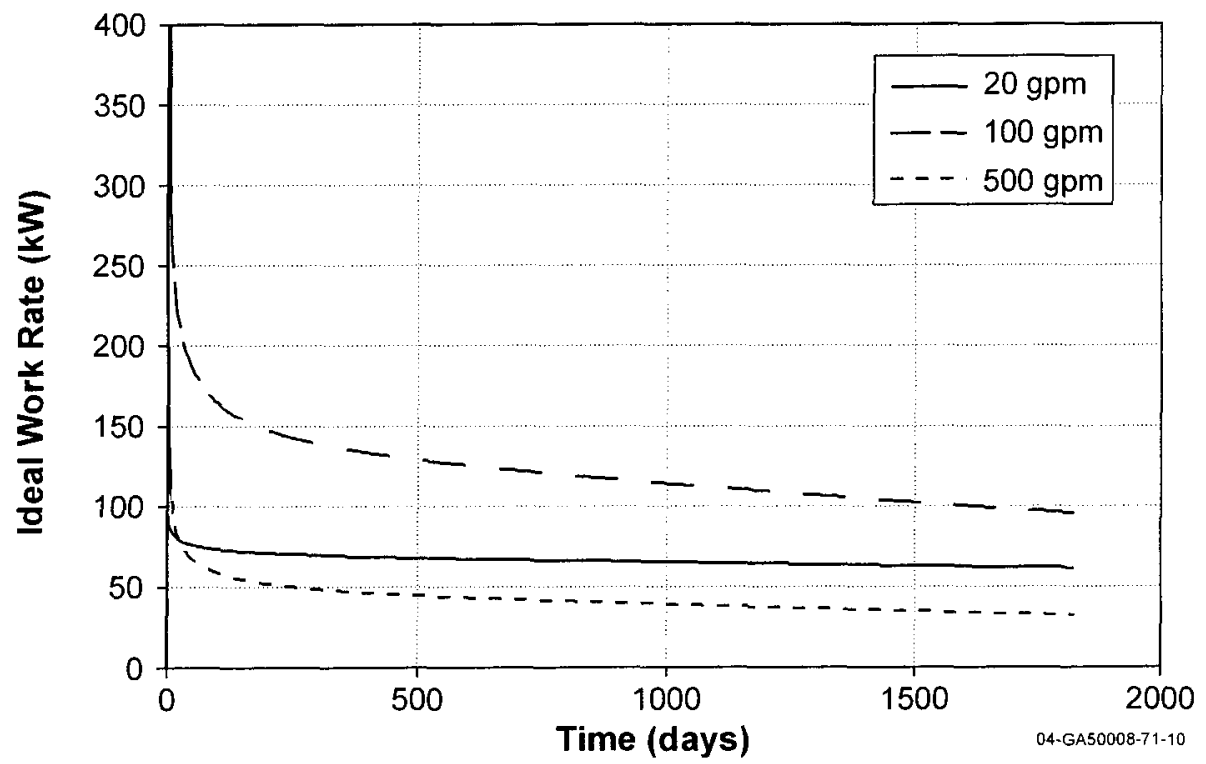

Figure 13. Ideal work extraction rate for circulation rates of 20,100 , and $500 \mathrm{gpm}$ with the $100 \mathrm{gpm}$ case having the highest ideal work extraction rate.

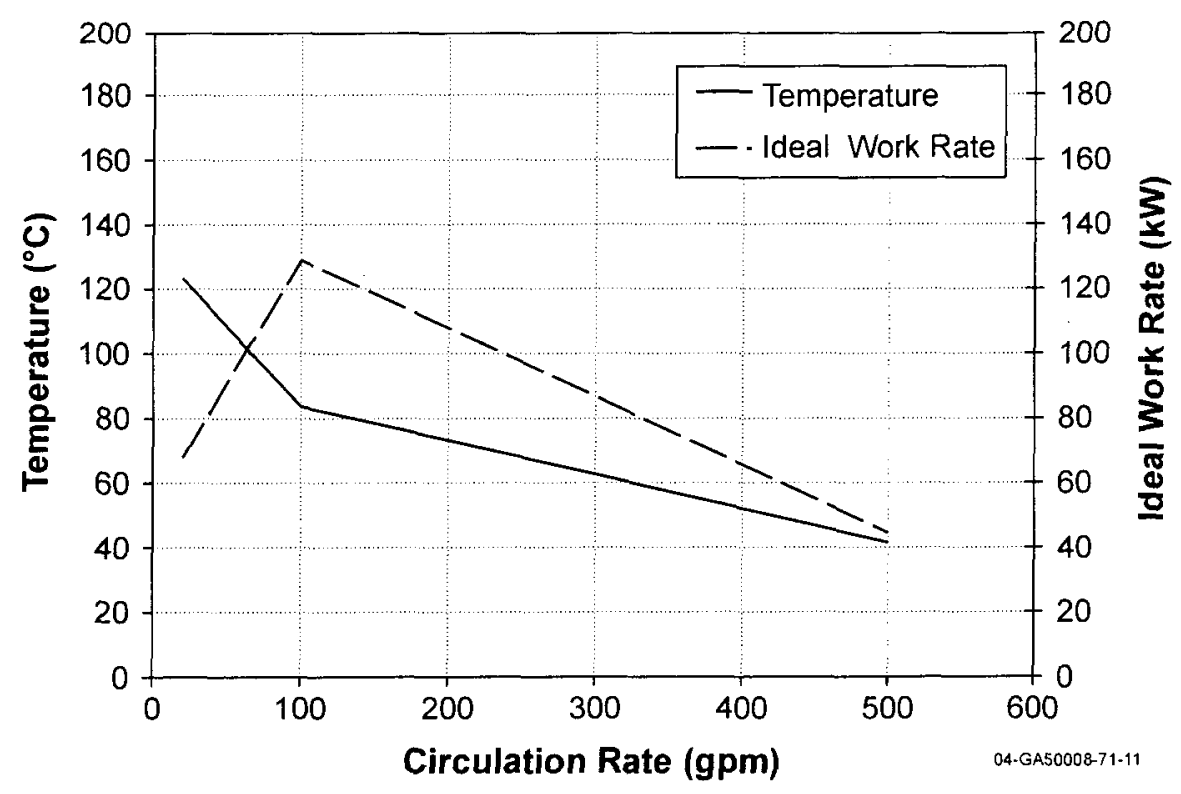

Figure 14. Plot of produced fluid temperature and ideal work extraction rates as a function of circulation rate at 500 days (PSS) illustrating an optimal circulation rate of $100 \mathrm{gpm}$.

\subsection{Wellbore Diameters}

Recognizing that contact surface area between the fluid and formation and residence time strongly affect ideal work rate, a logical wellbore modification is to increase its diameter. We varied the wellbore diameter from the base case value of $311 \mathrm{~mm}$ (12.25 in.) to $660.4 \mathrm{~mm}$ (26 in.). Temperature histories for these runs are given in Figure 15. At 500 days, the fluid returns temperature was $84^{\circ} \mathrm{C}\left(183^{\circ} \mathrm{F}\right)$ for the 311 $\mathrm{mm}\left(12.25 \mathrm{in}\right.$.) diameter wellbore and $95^{\circ} \mathrm{C}\left(203^{\circ} \mathrm{F}\right)$ for the $660.4 \mathrm{~mm}(26 \mathrm{in}$.) diameter wellbore. Despite increasing the residence time by a factor of 5.0 and the contact surface area by a factor of $2.0, \mathrm{~T}_{\mathrm{PSS}}$ differs 
by only $11^{\circ} \mathrm{C}\left(19.8^{\circ} \mathrm{F}\right)$, a $13 \%$ increase. The ideal work extraction rates are $129 \mathrm{~kW}(440.2 \mathrm{e}+3 \mathrm{BTU} / \mathrm{h})$ and $179 \mathrm{~kW}(610.8 \mathrm{e}+3 \mathrm{BTU} / \mathrm{h})$ for the $311 \mathrm{~mm}(12.25 \mathrm{in}$.) and $660.4 \mathrm{~mm}$ (26 in.) diameter wellbores, respectively, at 500 days. Ideal work at PSS (see Figure 16) increased by a factor of 1.4 with the larger wellbore. Thus, while increasing wellbore diameter enhances energy extraction, the improvements are likely offset by increased costs of drilling and casing the larger well.

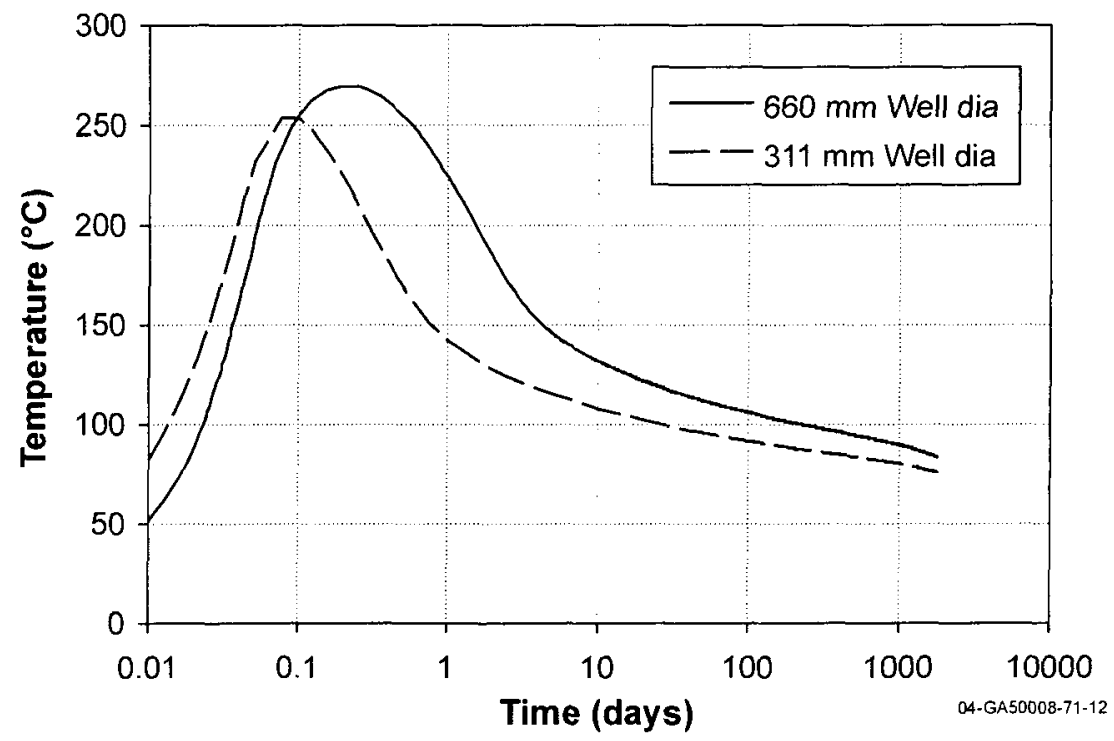

Figure 15. Fluid return temperature history for two different wellbore diameters The larger annular volume facilitates larger fluid residence times and higher temperature gain.

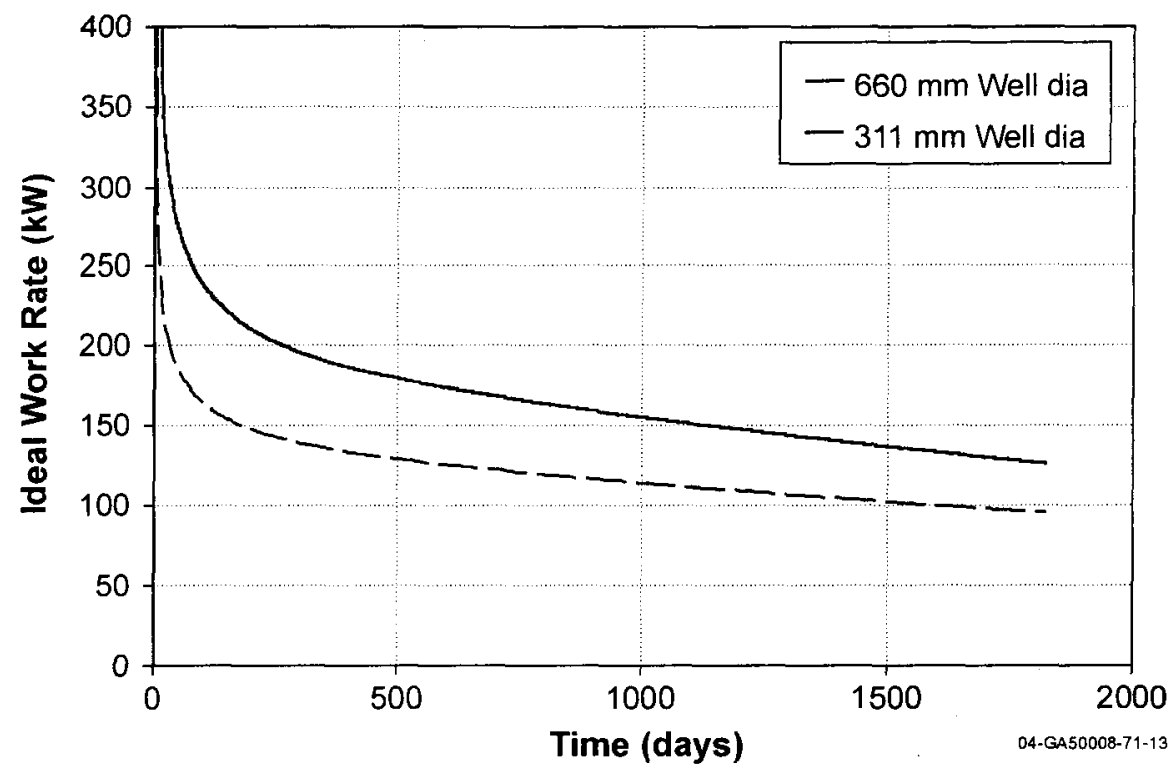

Figure 16. Ideal work extraction rate histories for the two wellbore diameters. The $660.4 \mathrm{~mm}$ wellbore diameter has the higher ideal work extraction rate. 


\subsection{Wellbore Casing Length}

We varied the wellbore casing length to study its effect on the wellbore heat exchanger performance. We ran three different cases with cemented casing lengths of $1,524 \mathrm{~m}(5,000 \mathrm{ft})$ for Case 1 , $3,048 \mathrm{~m}(10,000 \mathrm{ft})$ for Case 2, and 4,572 $\mathrm{m}(15,000 \mathrm{ft})$ for Case 3. The circulation rate was maintained at $100 \mathrm{gpm}(6.3 \mathrm{~kg} / \mathrm{s})$. The effective thermal conductivity of steel casing and cement combined was $1.1 \mathrm{~W} / \mathrm{m}^{\circ} \mathrm{C}\left(0.6356 \mathrm{Btu} / \mathrm{ft} . \mathrm{h}^{\circ} \mathrm{F}\right)$, its combined effective volumetric heat capacity was $1,693 \mathrm{~kJ} / \mathrm{m}^{3 \circ} \mathrm{C}$ $\left(25.23 \mathrm{BTU} / \mathrm{ft}^{3 \circ} \mathrm{F}\right)$, and the effective thermal diffusivity was $6.4973 \mathrm{e}-7 \mathrm{~m}^{2} / \mathrm{s}\left(6.9936 \mathrm{e}-6 \mathrm{ft}^{2} / \mathrm{s}\right)$. Heat transfer from a conductive regime into an advecting regime is directly proportional to thermal conductivity and inversely proportional to the square root of thermal diffusivity $\left(K / \kappa^{1 / 2}[1,365\right.$ $\left.\left.\mathrm{J} / \mathrm{m}^{2} \sqrt{s}_{\mathrm{s}^{\circ}} \mathrm{C}\left(6.6777 \mathrm{e}-2 \mathrm{BTU} / \mathrm{ft}^{2} \sqrt{s}^{\circ} \mathrm{F}\right)\right]\right)$, where $\mathrm{K}$ is thermal conductivity and $\mathrm{\kappa}$ is the thermal diffusivity (Carslaw and Jaeger 1959). The fluid residence time in the annulus is 0.65 day (base case), 0.60 day (Case 1), 0.50 day (Case 2) and 0.40 day (Case 3). This difference in fluid residence time is due to the changes in annular volume. The effluent fluid temperature history plot is given in Figure 17. The insignificant difference in the fluid returns temperature for different casing lengths could be attributed to the small difference in the overall heat transfer coefficients between the cased and uncased portions of the well (see Appendix A).

\subsection{Tubing Properties}

We varied the tubing properties to see what effect they had on produced fluid temperature. The tubing insulation was changed to a perfect insulator in one study, the tubing size was increased in another.

Temperature histories summarizing these studies are given in Figure 18. The effluent fluid temperature at the $100 \mathrm{gpm}(6.3 \mathrm{~kg} / \mathrm{s})$ circulation rate increased from $83.8^{\circ} \mathrm{C}\left(182^{\circ} \mathrm{F}\right)$ to $86^{\circ} \mathrm{C}\left(187^{\circ} \mathrm{F}\right)$ and to $86.6^{\circ} \mathrm{C}$

$\left(188^{\circ} \mathrm{F}\right)$ by making the insulation thermal conductivity ten times lower and zero, respectively. Comparing PSS fluid returns temperature of cases with increased insulation to the base case with realistic insulation value $\left(0.07 \mathrm{~W} / \mathrm{m}^{\circ} \mathrm{C}\left[0.04045 \mathrm{BTU} / \mathrm{ft} . \mathrm{h}^{\circ} \mathrm{F}\right]\right.$; Prats 1986$)$, the ideal case of perfect insulation indicates that tubing insulation beyond a realistic value did not have a significant effect for a circulation rate of 100 gpm $(6.3 \mathrm{~kg} / \mathrm{s})$. As the circulation rate increases the fluid residence time in the tubing decreases, and consequently, the effect of higher tubing insulation also decreases. The fluid residence time in the 76.2 $\mathrm{mm}$ (3.0 in.) internal diameter tubing at $100 \mathrm{gpm}(6.3 \mathrm{~kg} / \mathrm{s})$ circulation rate was 0.047 day. Except for the initial short transient period, the produced fluid temperature history for the tubing diameter of $127 \mathrm{~mm}$ (5.0 in.) was not significantly different from the base case with tubing diameter of $88.9 \mathrm{~mm}$ (3.5 in.). Thus, the tubing properties beyond realistic values proved to be of secondary importance to energy extraction efficiency.

Kohl, Brenni, and Eugster (2002) investigated the effect of insulation thermal conductivity. Their study concluded that the insulation thermal conductivity had an effect on the effluent fluid temperature. They used different wellbore configuration and circulation rates in their study. For insulation, they used two concentric tubes with the inner tube fully fitted into the outer one and insulation maintained by a vacuum pump with the individual long double walled tubes connected by $0.1 \mathrm{~m}$ (3.94 in.) long metallic sleeves. Their study acknowledges that the thermal role of the sleeves remains unclear; our model provides a uniform insulation layer on the outer surface of tubing. Their study used a $22.4 \mathrm{gpm}$ (1.41 $\mathrm{kg} / \mathrm{s})$ circulation rate; our study used a $100 \mathrm{gpm}(6.3 \mathrm{~kg} / \mathrm{s})$ circulation rate. The differences in the insulation effects could be attributed to the different wellbore configuration (including insulation) and circulation rates. The insulation thermal conductivity for our wellbore configuration and circulation rate, had a second order effect beyond realistic insulation. 


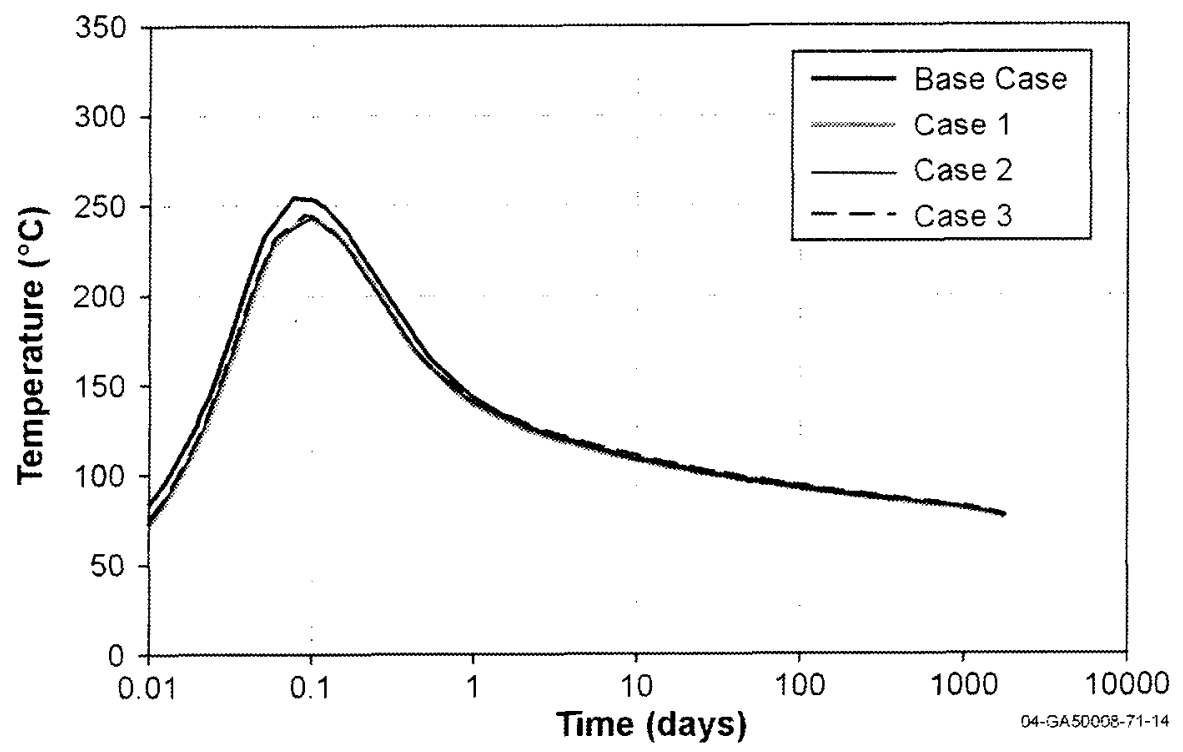

Figure 17. Effluent fluid temperature for varying wellbore casing lengths

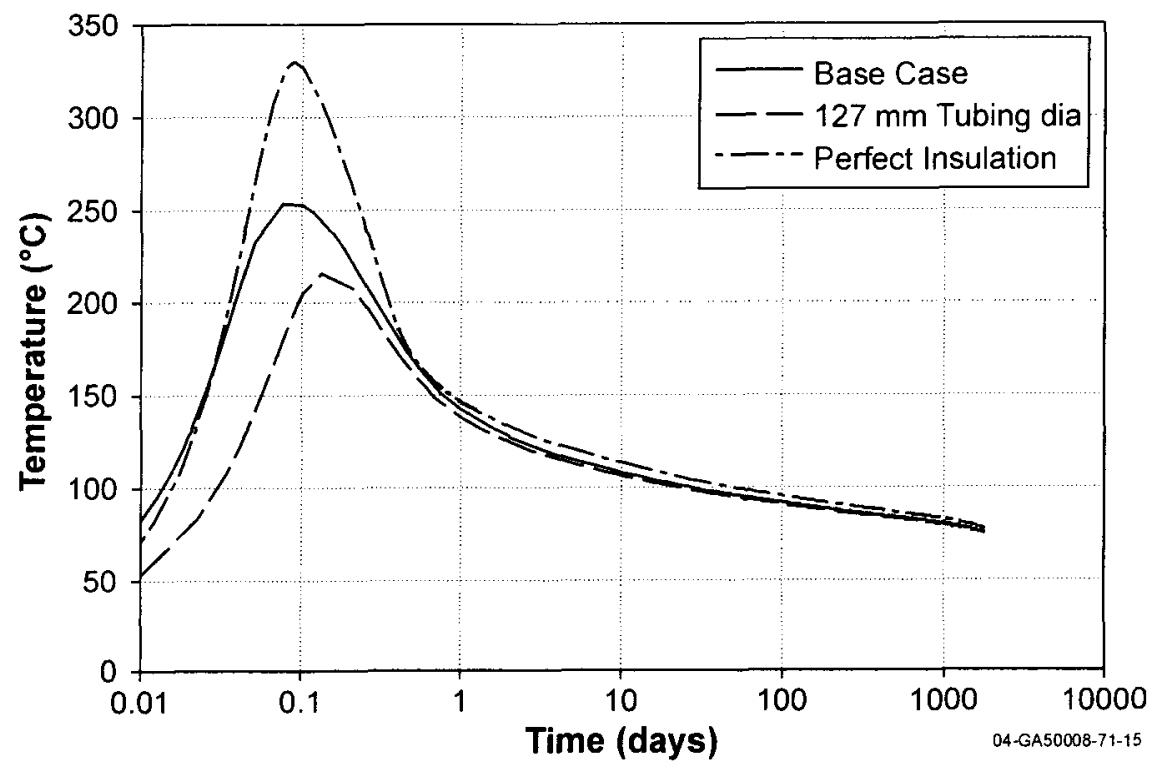

Figure 18. Effluent fluid temperature history plot for different tubing properties (insulation thermal conductivity and tubing diameter) at a circulation rate of $100 \mathrm{gpm}$ illustrating the insignificant effect of tubing properties.

\subsection{Working Fluid Properties}

We analyzed the volumetric heat capacity of the working fluid. We used water as our original working fluid, which has a volumetric heat capacity $(\rho C p)$ of approximately $4,186 \mathrm{~kJ} / \mathrm{m}^{3 \circ} \mathrm{C}(62.37$ $\mathrm{BTU} / \mathrm{ft}^{3 \circ} \mathrm{F}$ ) at standard conditions. We analyzed the effect of different working fluids by independently varying fluid density and specific heat capacity. Transport properties of the fluid such as viscosity were 
ignored in this study since friction drop, flow regime, etc., were also ignored, and heat conduction in the advecting fluid is negligible. Values for working fluid density and specific heat are given in Table 5.

Table 5. Thermal properties used for the working fluid sensitivity study.

\begin{tabular}{|c|c|c|c|}
\hline Case No. & $\begin{array}{c}\text { Fluid Density } \\
\left(\mathrm{kg} / \mathrm{m}^{3}\right)\end{array}$ & $\begin{array}{c}\text { Specific Heat } \\
\left(\mathrm{kJ} / \mathrm{kg}{ }^{\circ} \mathrm{C}\right)\end{array}$ & $\begin{array}{c}\text { Volumetric Heat Capacity } \\
\left(\mathrm{kJ} / \mathrm{m}^{\circ} \mathrm{C}\right)\end{array}$ \\
\hline A & 1,000 & 4.1868 & $4,186.8$ \\
\hline B & 1,000 & 41.868 & 41,868 \\
\hline C & 2,000 & 4.1868 & $8,373.6$ \\
\hline D & 2,000 & 20.934 & 41,868 \\
\hline E & 500 & 4.1868 & $2,093.4$ \\
\hline
\end{tabular}

The result of effluent fluid temperature history from this sensitivity study is plotted in Figure 19. The circulation rate was maintained at $100 \mathrm{gpm}(6.3 \mathrm{~kg} / \mathrm{s})$. Temperatures at PSS range from $113.2^{\circ} \mathrm{C}$ $\left(235.76^{\circ} \mathrm{F}\right)$ in the case of low volumetric heat capacity ( $\rho \mathrm{Cp}$ halved) to $34^{\circ} \mathrm{C}\left(93^{\circ} \mathrm{F}\right)$ for Cases $\mathrm{B}$ and $\mathrm{D}$ ( $\rho \mathrm{Cp}$ increased tenfold). The similarity in temperature histories for cases B and D demonstrates that volumetric heat capacity- $\rho \mathrm{Cp}$, not $\rho$ or $\mathrm{Cp}$-independently governs energy extraction.

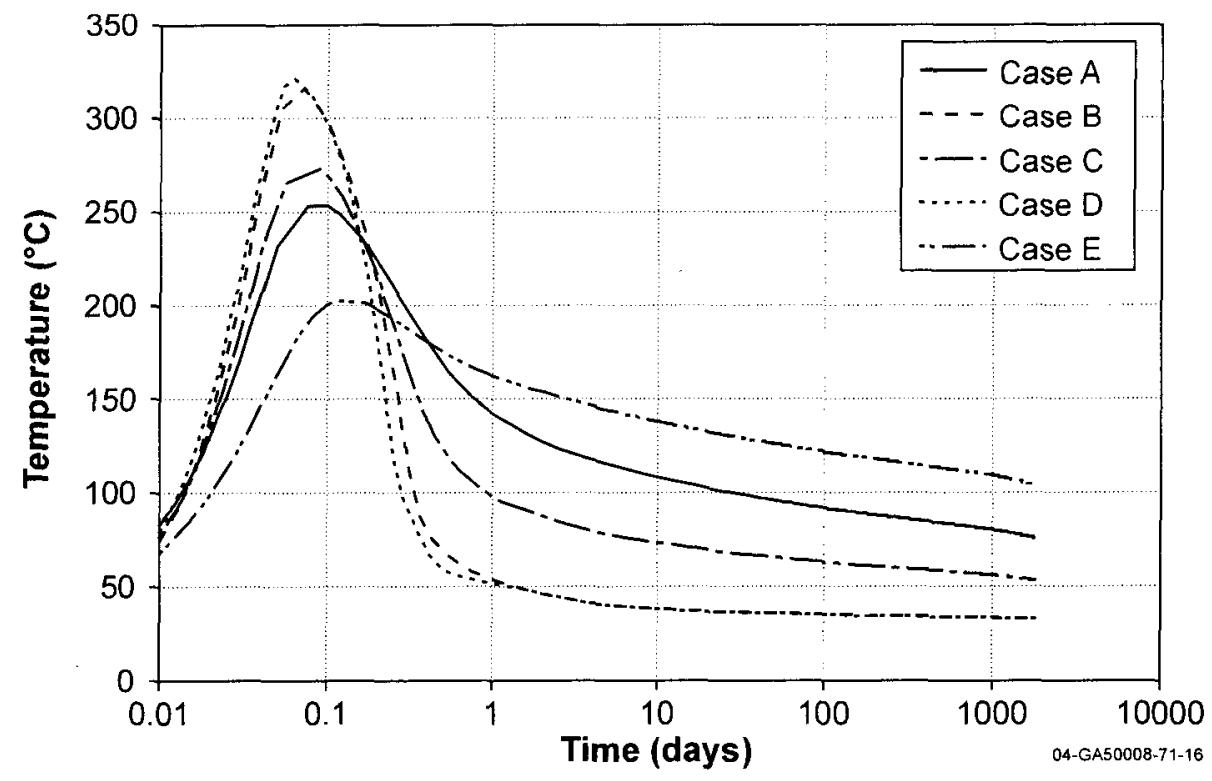

Figure 19. Produced fluid temperature histories for different working fluid cases showing that fluids with larger volumetric heat capacity have lower temperatures.

Since working fluid properties affect ideal work, which is based on enthalpy and entropy specific to the working fluid, it was not calculated. Instead, thermal energy production rates are plotted in Figure 20. Figures 19 and 20 show an interesting paradox-fluids with larger volumetric heat capacity have lower temperatures but larger thermal energy density. This is summarized in Figure 21, which illustrates a fundamental problem in identifying the optimum working fluid. Work extraction potential is measured against a rejection temperature; there is a minimum fluid temperature for which energy can be 
extracted. Given the PSS temperature results in this study, it appears that water is nearly the ideal working fluid.

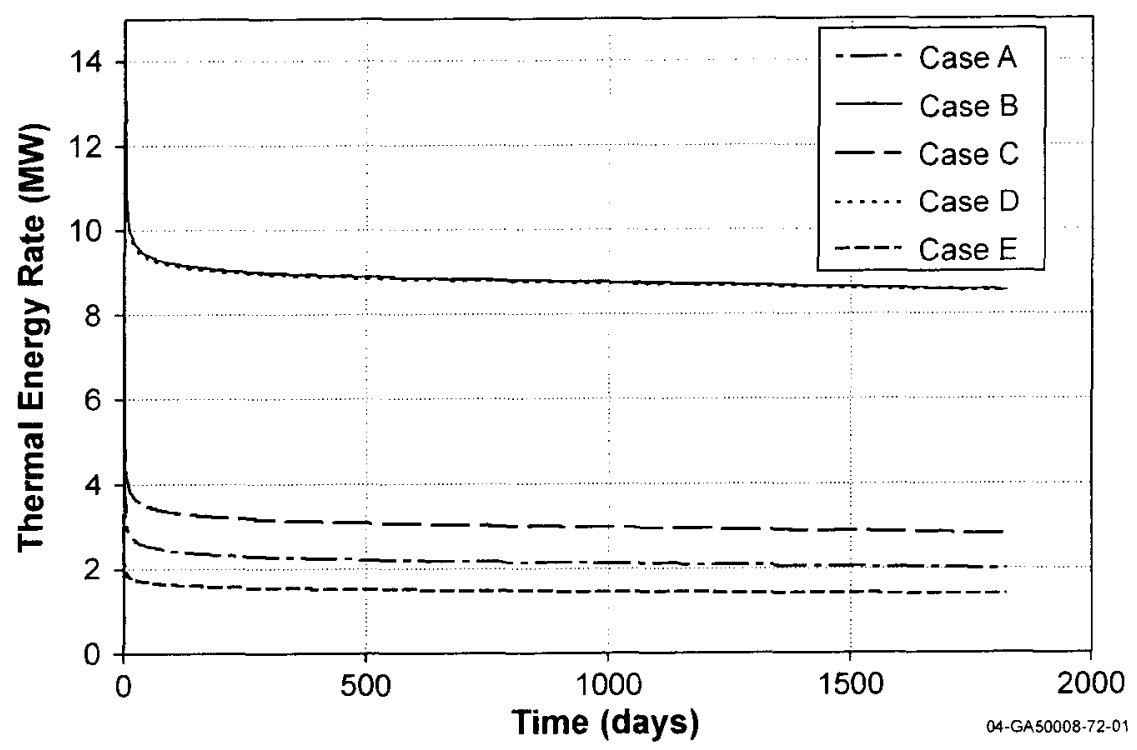

Figure 20. Thermal energy flow rate history for different working fluid cases.

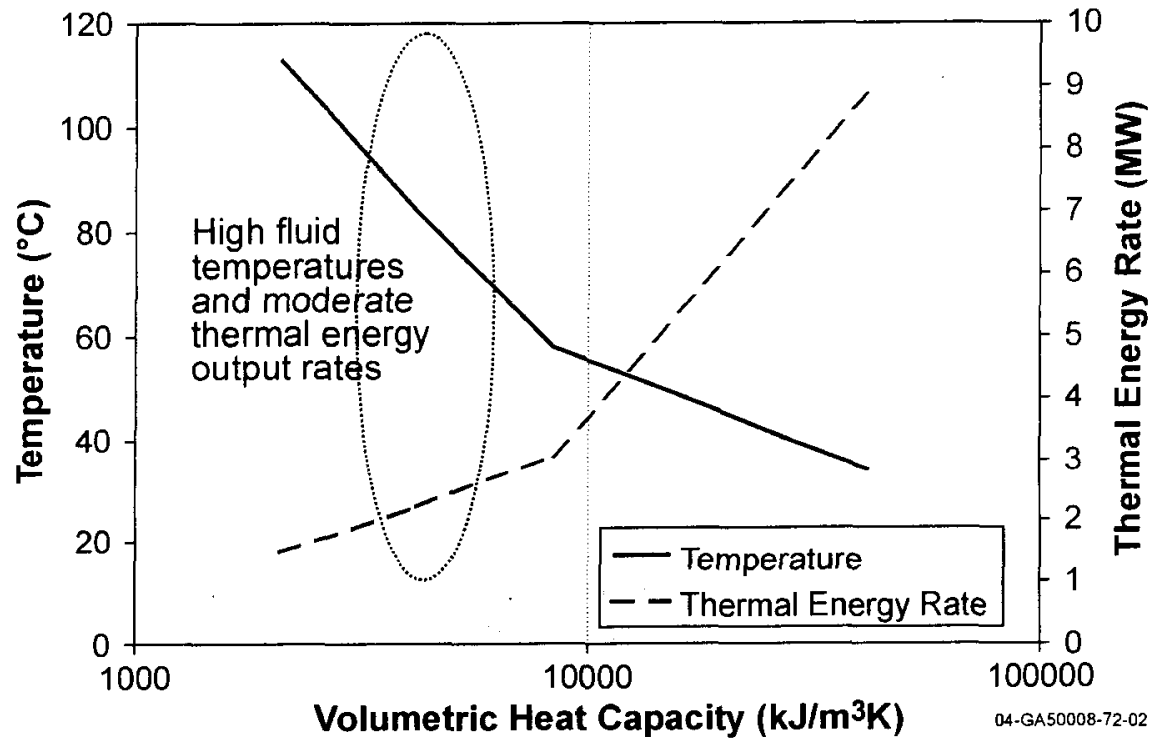

Figure 21. Pseudosteady-state effluent fluid temperature and thermal energy output rate as a function of volumetric heat capacity.

\subsection{Basal Heat Flux}

Recognizing the WBHX concept is not tied to any particular geologic region, we also conducted sensitivity studies on regional parameters. We first studied sensitivity to basal heat flux, which was varied between $0.1 \mathrm{~W} / \mathrm{m}^{2}\left(0.0317 \mathrm{BTU} / \mathrm{ft}^{2} . \mathrm{h}\right)$ to $0.5 \mathrm{~W} / \mathrm{m}^{2}\left(0.1585 \mathrm{BTU} / \mathrm{ft}^{2} . \mathrm{h}\right)$. In all cases, bottomhole temperature was maintained at $350^{\circ} \mathrm{C}\left(662^{\circ} \mathrm{F}\right)$, so varying the heat flux was equivalent to expanding or 
contracting the well depth. The well depths varied from $5,593 \mathrm{~m}(18,350$. $\mathrm{ft})$ for a heat flux of $0.1 \mathrm{~W} / \mathrm{m}^{2}$ $\left(0.0317 \mathrm{BTU} / \mathrm{ft}^{2} . \mathrm{h}\right)$, to $2,796.5 \mathrm{~m}(9,175 . \mathrm{ft})$ for $0.2 \mathrm{~W} / \mathrm{m}^{2}\left(0.0634 \mathrm{BTU} / \mathrm{ft}^{2} . \mathrm{h}\right)$, and to $1,119 \mathrm{~m}(3,671 . \mathrm{ft})$ for $0.5 \mathrm{~W} / \mathrm{m}^{2}\left(0.1585 \mathrm{BTU} / \mathrm{ft}^{2} . \mathrm{h}\right)$, which were obtained using Fourier's law of heat conduction. Since the surface and bottomhole temperatures were fixed, we calculated initial temperature gradients in the formation to be $0.0578^{\circ} \mathrm{C} / \mathrm{m}\left(0.03171^{\circ} \mathrm{F} / \mathrm{ft}\right), 0.1156^{\circ} \mathrm{C} / \mathrm{m}\left(0.06342^{\circ} \mathrm{F} / \mathrm{ft}\right)$, and $0.289^{\circ} \mathrm{C} / \mathrm{m}\left(0.15856^{\circ} \mathrm{F} / \mathrm{ft}\right)$ for a basal heat flux of $0.1 \mathrm{~W} / \mathrm{m}^{2}\left(0.0317 \mathrm{BTU} / \mathrm{ft}^{2} . \mathrm{h}\right), 0.2 \mathrm{~W} / \mathrm{m}^{2}\left(0.0634 \mathrm{BTU} / \mathrm{ft}^{2} . \mathrm{h}\right)$, and $0.5 \mathrm{~W} / \mathrm{m}^{2}(0.1585$ $\left.\mathrm{BTU} / \mathrm{ft}^{2} . \mathrm{h}\right)$ respectively.

The temperature histories and ideal work extraction rate histories for the three cases of heat flux are given in Figures 22 and 23, respectively. At PSS, the effluent fluid temperatures were $83.7^{\circ} \mathrm{C}\left(183^{\circ} \mathrm{F}\right)$ for a heat flux of $0.1 \mathrm{~W} / \mathrm{m}^{2}\left(0.0317 \mathrm{BTU} / \mathrm{ft}^{2} . \mathrm{h}\right), 58.5^{\circ} \mathrm{C}\left(137.3^{\circ} \mathrm{F}\right)$ for $0.2 \mathrm{~W} / \mathrm{m}^{2}\left(0.0634 \mathrm{BTU} / \mathrm{ft}^{2} . \mathrm{h}\right)$, and $40.5^{\circ} \mathrm{C}\left(105^{\circ} \mathrm{F}\right)$ for $0.5 \mathrm{~W} / \mathrm{m}^{2}\left(0.1585 \mathrm{BTU} / \mathrm{ft}^{2} . \mathrm{h}\right)$. Similarly, the PSS ideal work extraction rates for 0.1 $\mathrm{W} / \mathrm{m}^{2}\left(0.0317 \mathrm{BTU} / \mathrm{ft}^{2} . \mathrm{h}\right), 0.2 \mathrm{~W} / \mathrm{m}^{2}\left(0.0634 \mathrm{BTU} / \mathrm{ft}^{2} . \mathrm{h}\right)$, and $0.5 \mathrm{~W} / \mathrm{m}^{2}\left(0.1585 \mathrm{BTU} / \mathrm{ft}^{2} . \mathrm{h}\right)$ were $129 \mathrm{~kW}$ $(440.2 \mathrm{e}+3 \mathrm{BTU} / \mathrm{h}), 43 \mathrm{~kW}(146.7 \mathrm{e}+3 \mathrm{BTU} / \mathrm{h})$, and $9.3 \mathrm{~kW}(31.733 \mathrm{e}+3 \mathrm{BTU} / \mathrm{h})$, respectively. The plot illustrates that, for a fixed maximum downhole temperature, deeper wells yield higher produced fluid temperatures. The ideal work extraction rate follows the same trend-under conditions of fixed bottomhole temperature, the lower heat flux, and hence deeper wells, are favorable for energy extraction. However, economic considerations (ignored in this study) would argue the reverse.

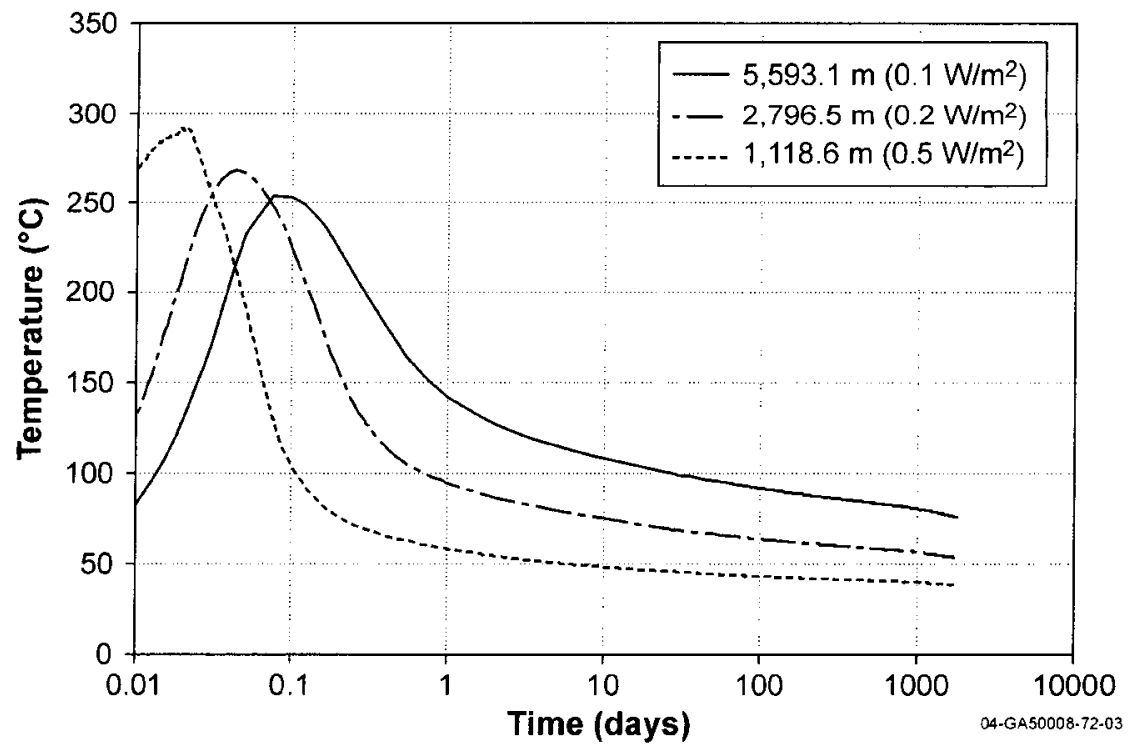

Figure 22. Effluent fluid temperature history plot for varying basal heat flux. The lowest basal heat flux case has the highest PSS effluent fluid temperature for fixed bottomhole temperature. 


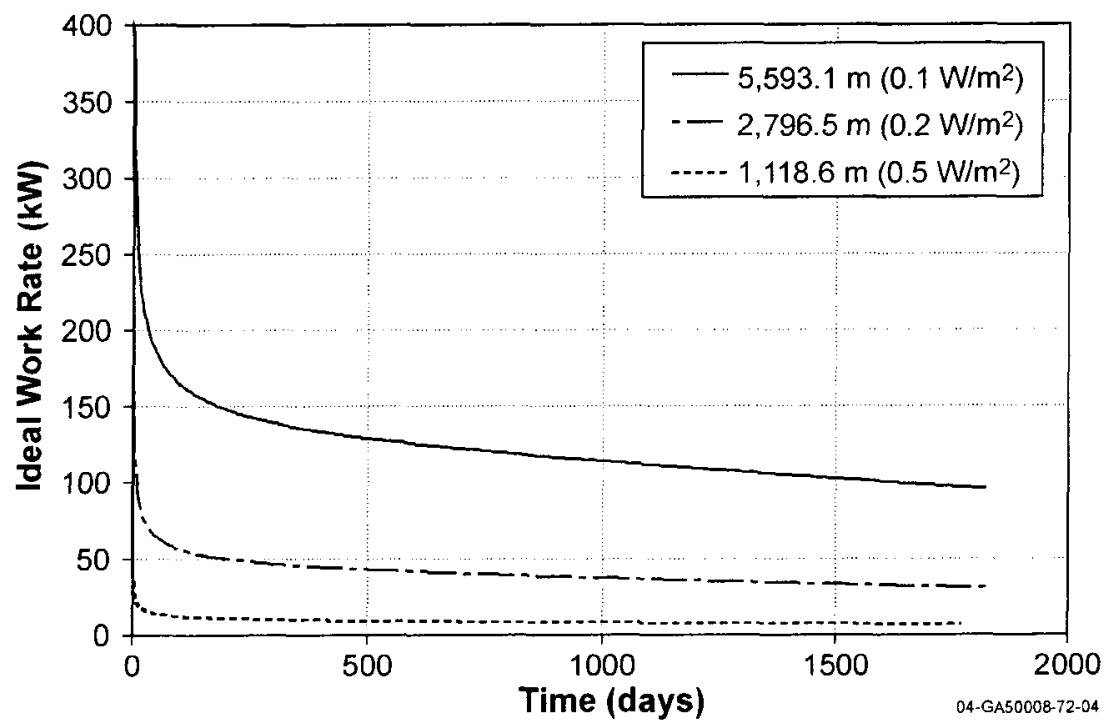

Figure 23. Ideal work extraction rate as a function of basal heat flux. The lowest basal heat flux case has the highest ideal work extraction rate for fixed bottomhole temperature.

The fluid residence times and contact surface areas are a function of the wellbore depth. The larger residence time of the circulating fluid and heat transfer area in the deeper well lead to more energy transfer and higher fluid temperature at PSS. The wellbore depth has a greater influence compared to the formation thermal gradient on the energy extraction. The calculation of average formation heat transfer in Appendix $\mathrm{C}$ proves mathematically, using a simplified model, that the wellbore depth had a primary effect on the heat extraction and the geothermal gradient had a secondary effect.

\subsection{Formation Thermal Properties}

We selected seven different formation types and studied the effects of varying formation thermal properties on the heat extraction process. The thermal properties of the different formations are given in Table 6. For convenience, these properties were taken from a compilation of sedimentary and evaporite formation types (Prats 1986); however, the range of properties is representative of essentially all rock types. Other than formation thermal properties, all other variables are as in the base case. Temperature histories for the various cases are given in Figure 24. As can be seen, the formation with the largest thermal conductivity and thermal volumetric heat capacity gives the highest fluid temperature. Shale with a high thermal conductivity and volumetric heat capacity led to the highest fluid return temperature while Bandera sandstone with low thermal conductivity and volumetric heat capacity led to the lowest fluid return temperature. At PSS, the Bandera sandstone formation case resulted in an effluent fluid temperature of $34^{\circ} \mathrm{C}\left(93^{\circ} \mathrm{F}\right)$, and the shale formation case resulted in an effluent fluid temperature of $86^{\circ} \mathrm{C}$ $\left(187^{\circ} \mathrm{F}\right)$.

The reason for dependence on both thermal conductivity and volumetric heat capacity is because heat transfer from a conductive regime into an advecting regime is directly proportional to thermal conductivity and inversely proportional to the square root of thermal diffusivity (Carslaw and Jaeger 1959). In fact, if the formations are ranked according to decreasing $\mathrm{K} / \mathrm{K}^{1 / 2}$, where $\kappa$ is the thermal diffusivity and K is thermal conductivity, PSS temperature histories (and work rates) correlate to that order. Figure 25 shows the ideal work extraction rate plotted as a function of $\mathrm{K} / \mathrm{K}^{1 / 2}$ and demonstrates the formation properties most appropriate for WBHX. 
Table 6. Thermal properties used for the formation thermal property sensitivity study.

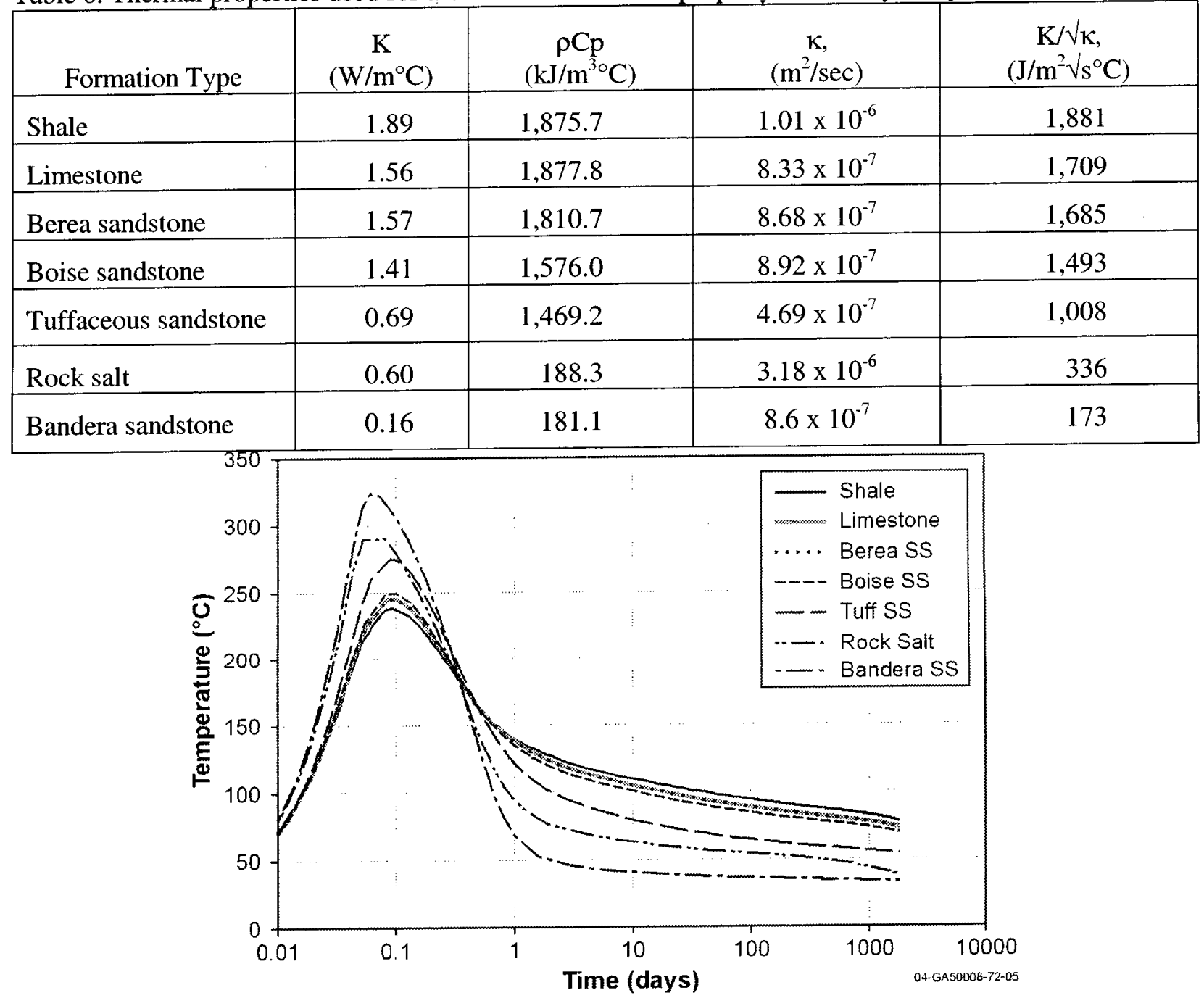

Figure 24. Produced fluid temperature history for different formation thermal properties. The shale case had the highest PSS effluent fluid temperature, while the Bandera Sandstone case had the lowest effluent fluid temperature. 


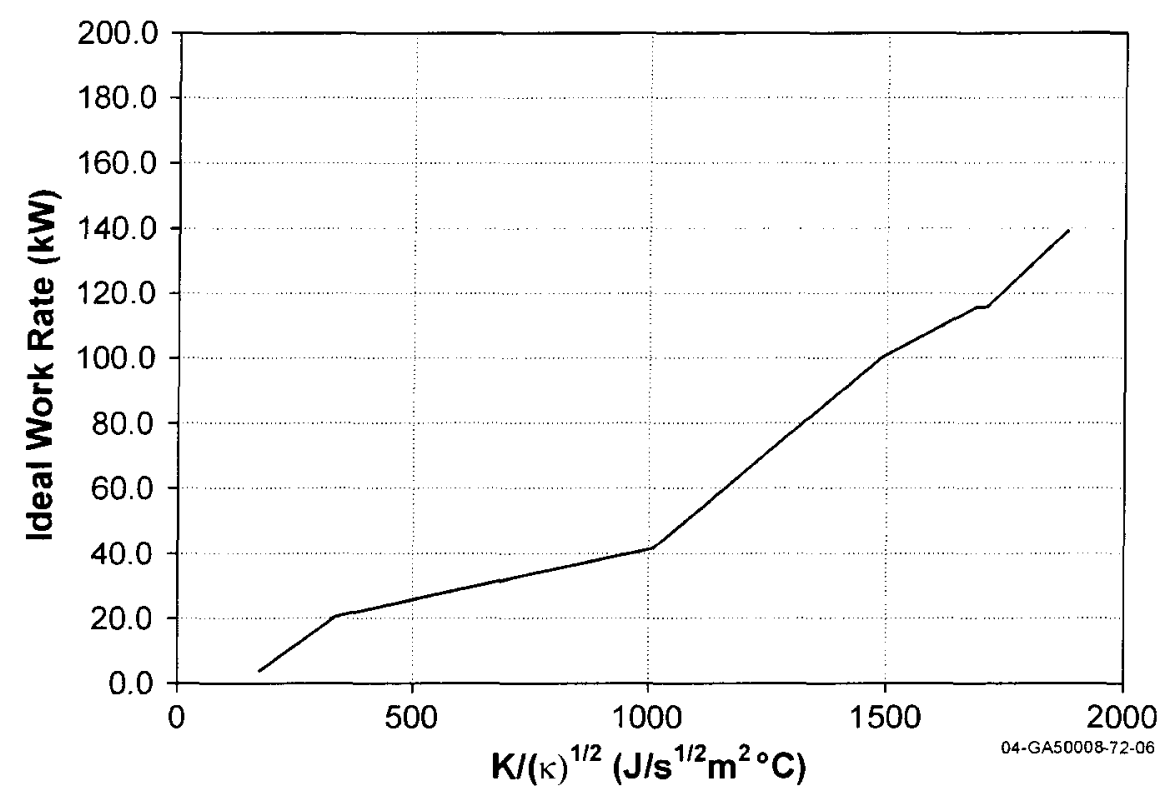

Figure 25. Pseudosteady state ideal work extraction rate plotted as a function of $K / \kappa^{1 / 2}$. The PSS ideal work rate correlates as a function of $\mathrm{K} / \mathrm{K}^{1 / 2}$.

\subsection{Natural Fluid Convection in Formation}

In order to study the effects of natural convection on the effluent fluid temperature and ideal work extraction rate, we modeled and compared a case with formation fluid convection to a case having no convection. The convection case was assigned a permeability of $9.869 \mathrm{e}-14 \mathrm{~m}^{2}(100 \mathrm{mD})$ and a porosity of $10 \%$. The top $762 \mathrm{~m}(2,500 \mathrm{ft})$ is conductive cap rock zone, the remainder is convective zone A steadystate aquifer boundary condition at the bottom allowed for fluid convection into the reservoir and another steady-state aquifer boundary condition at the edge from $610 \mathrm{~m}(2,000 \mathrm{ft})$ to $792.5 \mathrm{~m}(2,600 \mathrm{ft})$ allowed for fluid to flow out, thereby creating a natural convection cell. Figure 26 gives the formation temperature profiles for the convection case and the base case with no convection. Figure 27 plots the interstitial

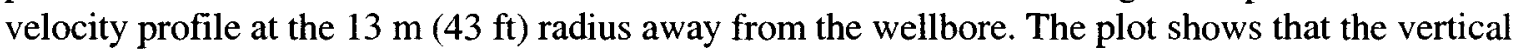
interstitial velocity averages about $0.3 \mathrm{~m} /$ day ( $1 \mathrm{ft} /$ day) upwards in the convection zone. Figure 28 shows the fluid return temperature history for the case with convection and without convection at circulation rates of $100 \mathrm{gpm}(6.3 \mathrm{~kg} / \mathrm{s})$ and a wellbore depth of $5,593.1 \mathrm{~m}(18,350 \mathrm{ft})$. Figure 29 plots the ideal work extraction rate history for the case with convection and without convection. The effluent fluid temperature was $84^{\circ} \mathrm{C}\left(183^{\circ} \mathrm{F}\right)$ for the no convection case, and $119^{\circ} \mathrm{C}\left(246^{\circ} \mathrm{F}\right)$ for the convection case. The ideal work extraction rate was $129 \mathrm{~kW}(440.2 \mathrm{e}+3 \mathrm{BTU} / \mathrm{h})$ in the no convection case, and $339 \mathrm{~kW}(1.1567 \mathrm{e}+6$ $\mathrm{BTU} / \mathrm{h})(163 \%$ increase $)$ in the convection case. 


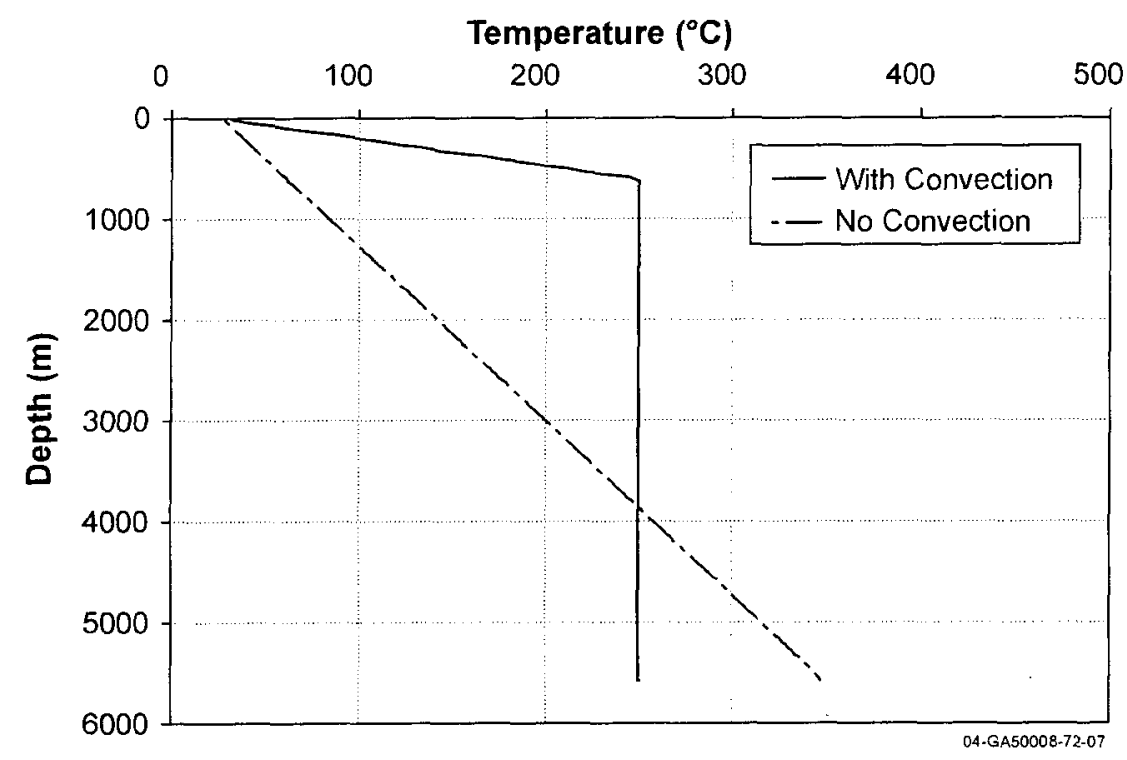

Figure 26. Initial formation temperature profiles for the case with and without convection.

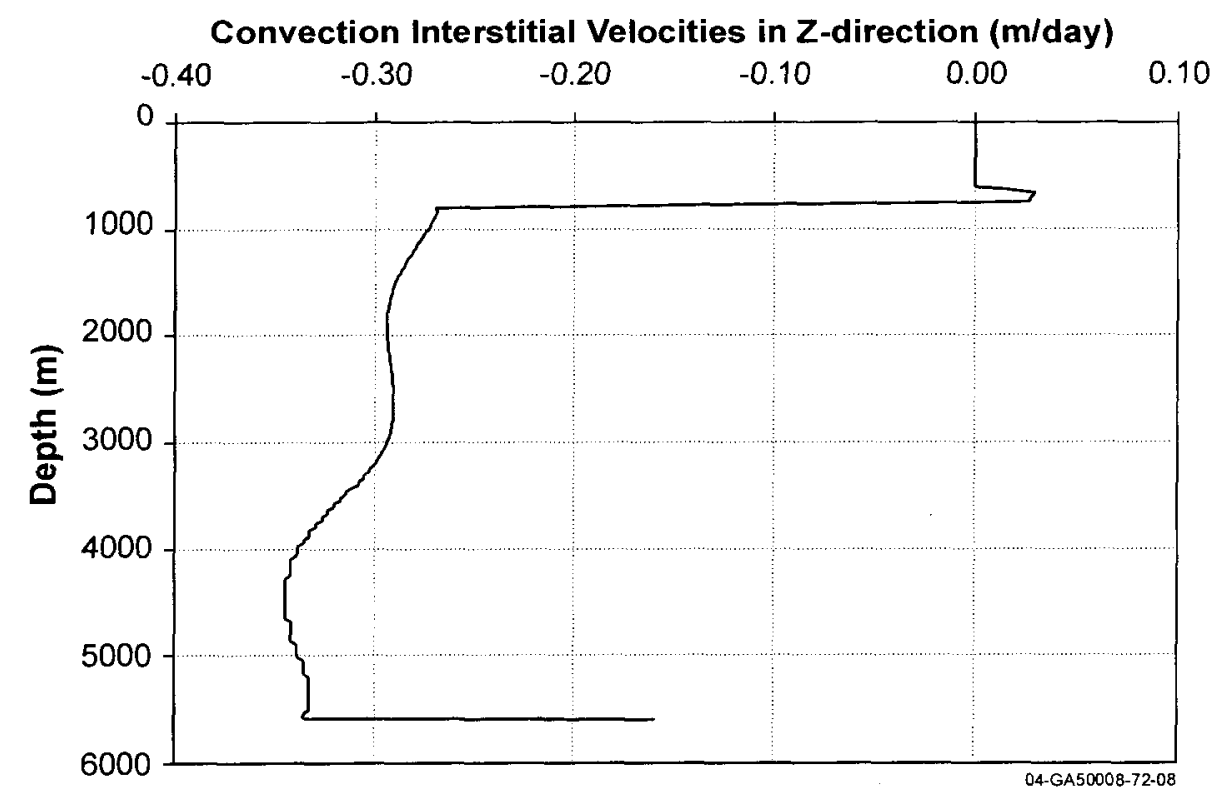

Figure 27. Fluid vertical interstitial velocities in the convection case at 500 days. 


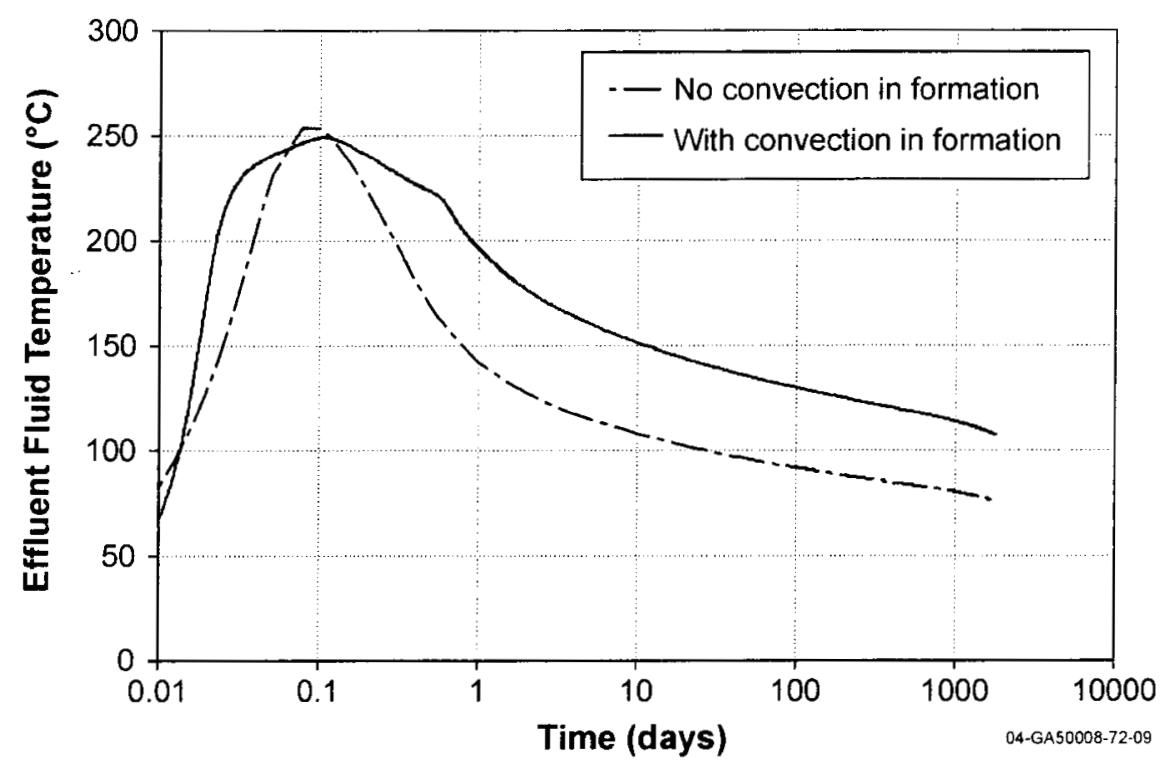

Figure 28. Effluent fluid temperature history comparison for the formation convection case vs. no convection case.

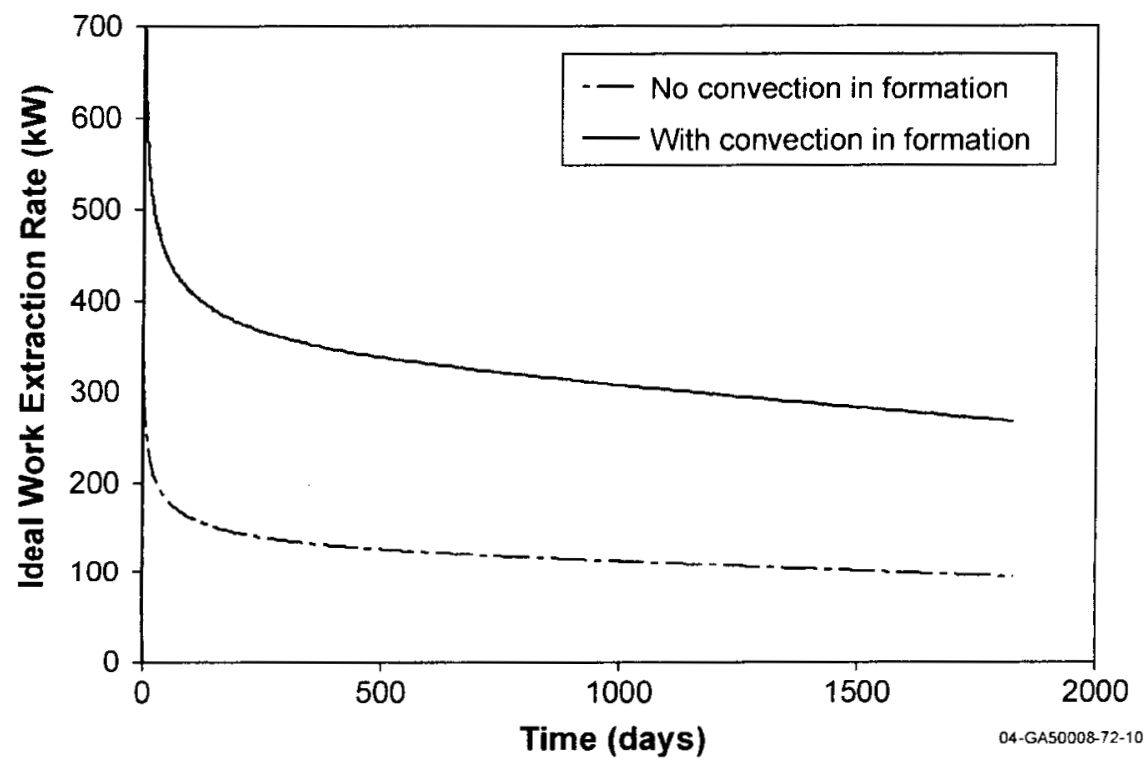

Figure 29. Ideal work extraction rate history comparison for the formation convection case vs. no convection case.

Natural convection of $0.3 \mathrm{~m} /$ day ( $1 \mathrm{ft} /$ day) at a constant temperature of $250^{\circ} \mathrm{C}\left(480^{\circ} \mathrm{F}\right)$ is a highly desirable hydrothermal system property. The point of the example is that, even in the presence of large natural convection cells, energy extraction from a wellbore is not technically feasible $(270 \mathrm{~kW}(921.3 \mathrm{e}+3$ $\mathrm{BTU} / \mathrm{h}$ ) at 5 years production). With this degree of natural convection, the obvious solution would be to perforate the well and produce the formation fluid - not a WBHX design. 


\section{BEST CASE SCENARIO}

We used the results of the sensitivity study (see Table 7) to construct the most optimistic set of parameters for WBHX (see Table 8). Results of the best case simulation are given in Figures 30 and 31. At the onset of PSS, the fluid temperature is approximately $98^{\circ} \mathrm{C}\left(208.4^{\circ} \mathrm{F}\right)$ and the ideal work extraction rate is $198 \mathrm{~kW}(675.6 \mathrm{e}+3 \mathrm{BTU} / \mathrm{h})$. We believe these results to be optimistic for several reasons, which include a $350^{\circ} \mathrm{C}\left(662^{\circ} \mathrm{F}\right)$ bottomhole temperature, and especially, an ideal conversion of thermal energy to electric power. Our intent was to identify the most optimistic set of formation and operational properties to estimate the ability to generate power using the WBHX concept.

Table 7. Summary of sensitivity study results at PSS.

\begin{tabular}{|c|c|c|c|}
\hline Parameter of study & Value & $\begin{array}{l}\text { Effluent Temperature } \\
\left({ }^{\circ} \mathrm{C}\right)\end{array}$ & $\begin{array}{c}\text { Ideal Work Rate } \\
(\mathrm{kW})\end{array}$ \\
\hline Base case & - & 84.0 & 129.0 \\
\hline \multirow{3}{*}{ Circulation Rate (gpm) } & 20.0 & 123.0 & 68.0 \\
\hline & 100.0 & 84.0 & 129.0 \\
\hline & 500.0 & 40.0 & 45.0 \\
\hline \multirow{2}{*}{ Wellbore Diameter (mm) } & 311.0 & 84.0 & 129.0 \\
\hline & 660.4 & 95.0 & 179.0 \\
\hline \multirow{3}{*}{ Wellbore Casing Length (m) } & 1524.0 & 84.0 & 129.0 \\
\hline & 3048.0 & 84.0 & 129.0 \\
\hline & 4572.0 & 84.7 & 133.0 \\
\hline \multirow{2}{*}{ Tubing Diameter (mm) } & 88.9 & 84.0 & 129.0 \\
\hline & 127.0 & 83.0 & 126.0 \\
\hline \multirow{3}{*}{$\begin{array}{l}\text { Tubing Insulation Thermal } \\
\text { Conductivity }\left(\mathrm{W} / \mathrm{m}^{\circ} \mathrm{C}\right)\end{array}$} & 0.07 & 84.0 & 129.0 \\
\hline & 0.007 & 86.0 & 139.0 \\
\hline & 0.0 & 86.6 & 141.0 \\
\hline \multirow{4}{*}{$\begin{array}{l}\text { Working Fluid Volumetric } \\
\text { Heat Capacity }\left(\mathrm{kJ} / \mathrm{m}^{3 \circ} \mathrm{C}\right)\end{array}$} & $2,093.4$ & 113.0 & - \\
\hline & $4,186.8$ & 84.0 & 129.0 \\
\hline & $8,373.6$ & 58.0 & - \\
\hline & 41,868 & 34.0 & - \\
\hline \multirow{3}{*}{ Basal Heat Flux $\left(\mathrm{W} / \mathrm{m}^{2}\right)$} & 0.1 & 84.0 & 129.0 \\
\hline & 0.2 & 59.0 & 43.0 \\
\hline & 0.5 & 41.0 & 9.3 \\
\hline \multirow{7}{*}{$\begin{array}{l}\text { Formation Thermal } \\
\text { Properties, } K / V_{\kappa}\left(J / m^{2} V_{s}{ }^{\circ} \mathrm{C}\right)\end{array}$} & 1,881 & 86.0 & 139.0 \\
\hline & 1,709 & 80.5 & 116.0 \\
\hline & 1,685 & 80.5 & 116.0 \\
\hline & 1,493 & 77.0 & 100.5 \\
\hline & 1,008 & 58.0 & 41.5 \\
\hline & 336 & 48.0 & 20.5 \\
\hline & 173 & 34.3 & 3.54 \\
\hline
\end{tabular}


Table 8. Best case description of well geometry and case parameters.

\begin{tabular}{|l|}
\hline \multicolumn{1}{|c|}{ Well Geometry } \\
\hline Tubing inner diameter $-76.2 \mathrm{~mm}$ \\
\hline Tubing outer diameter $-88.9 \mathrm{~mm}$ \\
\hline Insulation outer diameter $-101.6 \mathrm{~mm}$ \\
\hline Casing inner diameter $-228.6 \mathrm{~mm}$ \\
\hline Casing outer diameter $-244.475 \mathrm{~mm}$ \\
\hline Wellbore diameter $-660.4 \mathrm{~mm}$ \\
\hline Well depth $-5,593 \mathrm{~m}$ \\
\hline \\
\hline Basal Heat Flux $-0.1 \mathrm{~W} / \mathrm{m} 2$ \\
\hline Formation Thermal conductivity $-1.89 \mathrm{~W} / \mathrm{m}^{\circ} \mathrm{C}$ \\
\hline Formation volumetric heat capacity $-1,875.7 \mathrm{~kJ} / \mathrm{m}^{3}{ }^{\circ} \mathrm{C}$ \\
\hline Working fluid volumetric heat capacity $-4,186.8 \mathrm{~kJ} / \mathrm{m}^{3} .{ }^{\circ} \mathrm{C}$ \\
\hline Insulation Thermal Conductivity $-0.07 \mathrm{~W} / \mathrm{m}^{\circ} \mathrm{C}$ \\
\hline Circulation rate -100 gpm \\
\hline Surface temperature $-26.7^{\circ} \mathrm{C}$ \\
\hline Bottomhole temperature $-350^{\circ} \mathrm{C}$ \\
\hline
\end{tabular}

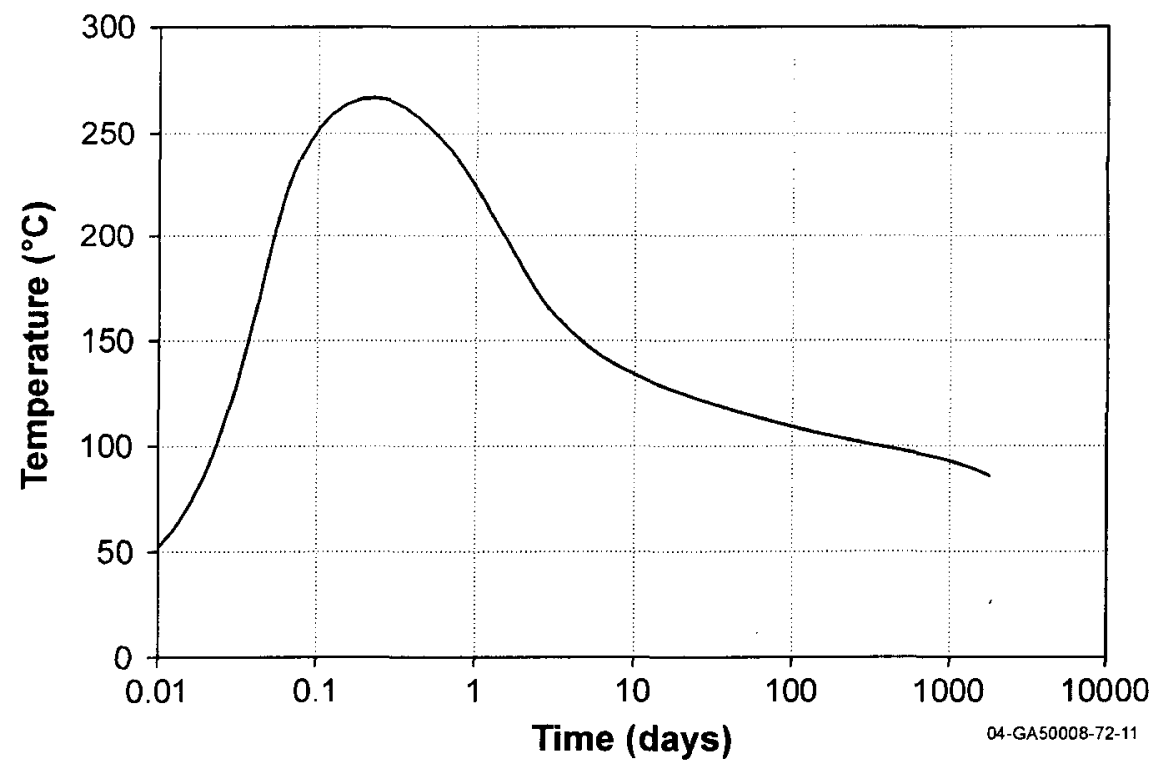

Figure 30. Produced fluid temperature history for the best case. 


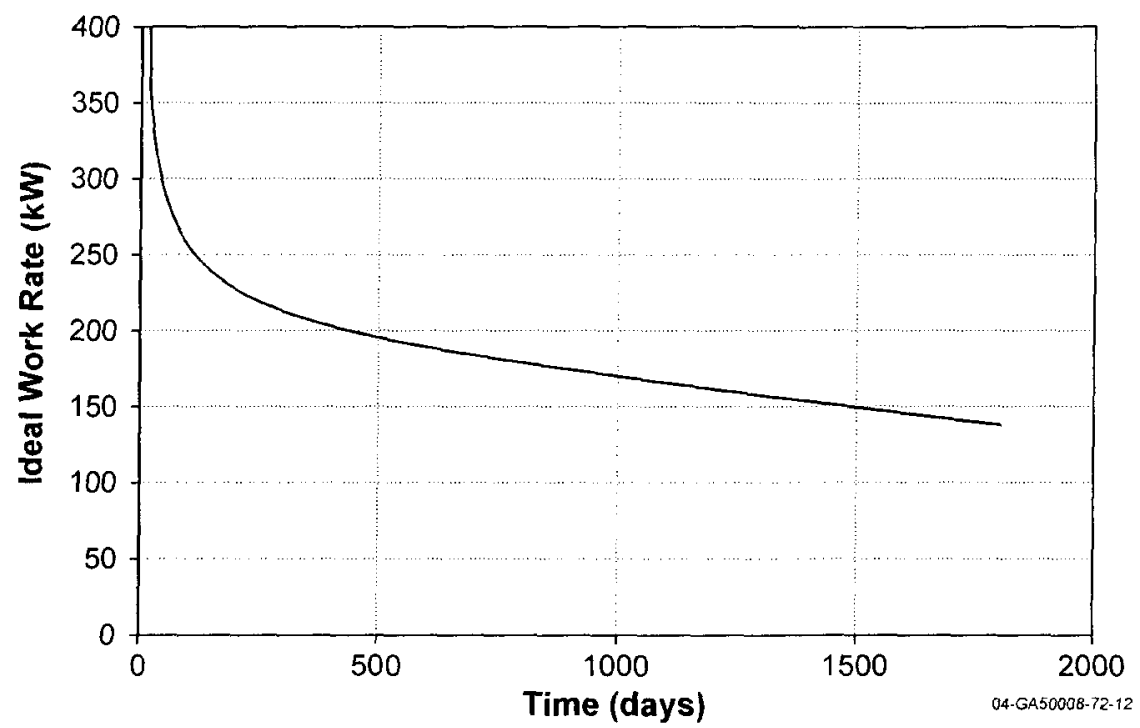

Figure 31. Ideal work extraction rate for the best case. 


\section{SPECIFIC CASE EXAMPLES}

We studied two cases to determine the feasibility of using a wellbore heat exchanger under those specific scenarios. The first case involved the use of a wellbore heat exchanger in a hypothetical reservoir with a body of magma at shallow depth. The second case had a wellbore heat exchanger installed under conditions similar to Northwest Geysers. We applied the optimal parameters determined from each study to our wellbore heat exchangers.

\subsection{Near Surface Magma}

In the near surface magma study, the source heat flux at the base was assigned a value of $1.34 \mathrm{~W} / \mathrm{m}^{2}\left(0.425 \mathrm{BTU} / \mathrm{ft}^{2} / \mathrm{hr}\right)$. The pressure at the tubing top in this case was 68 atm $(1,000 \mathrm{psia})$ to maintain single phase conditions in the wellbore. The fluid enthalpy and entropy are functions of pressure and temperature; hence, the ideal work extraction rate takes into account the pressure of the effluent fluid. Since the logging tools and well materials cannot withstand extremely high temperatures, the bottomhole temperature was constrained at $350^{\circ} \mathrm{C}\left(662^{\circ} \mathrm{F}\right)$. Based on the basal heat flux, the well depth was calculated to be $401 \mathrm{~m}(1,316 \mathrm{ft})$. The injection and ambient temperature was $40^{\circ} \mathrm{C}\left(104^{\circ} \mathrm{F}\right)$.

The circulation rate was $100 \mathrm{gpm}(6.3 \mathrm{~kg} / \mathrm{s})$ and the calculated fluid residence time in the annulus was 0.0242 day. Figure 32 plots the produced fluid temperature history. After 0.37 days, the produced fluid temperature drops to the circulation temperature of $40^{\circ} \mathrm{C}\left(104^{\circ} \mathrm{F}\right)$ for the $100 \mathrm{gpm}(6.3 \mathrm{~kg} / \mathrm{s})$ circulation rate. The ideal work extraction rate was $43 \mathrm{~kW}(146.7 \mathrm{e}+3 \mathrm{BTU} / \mathrm{h})$ at PSS as shown in Figure 33. Thus, the near surface magma led to a high geothermal gradient restricting the wellbore to shallow depths. The nominal flow rates with shallow wells resulted in extremely small fluid residence times, and rendered the wellbore heat exchanger unfeasible under such environments.

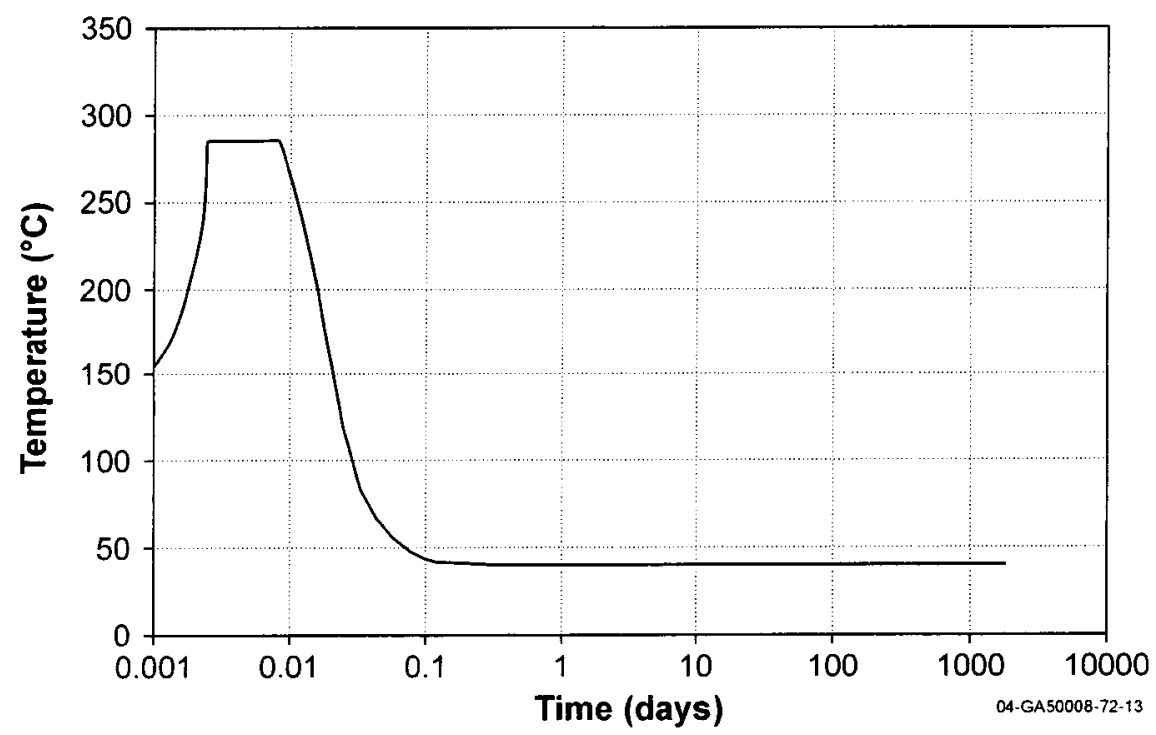

Figure 32. Produced fluid temperature history for the near surface magma case. The effluent fluid returns quickly to injection temperature due to its small residence time. 


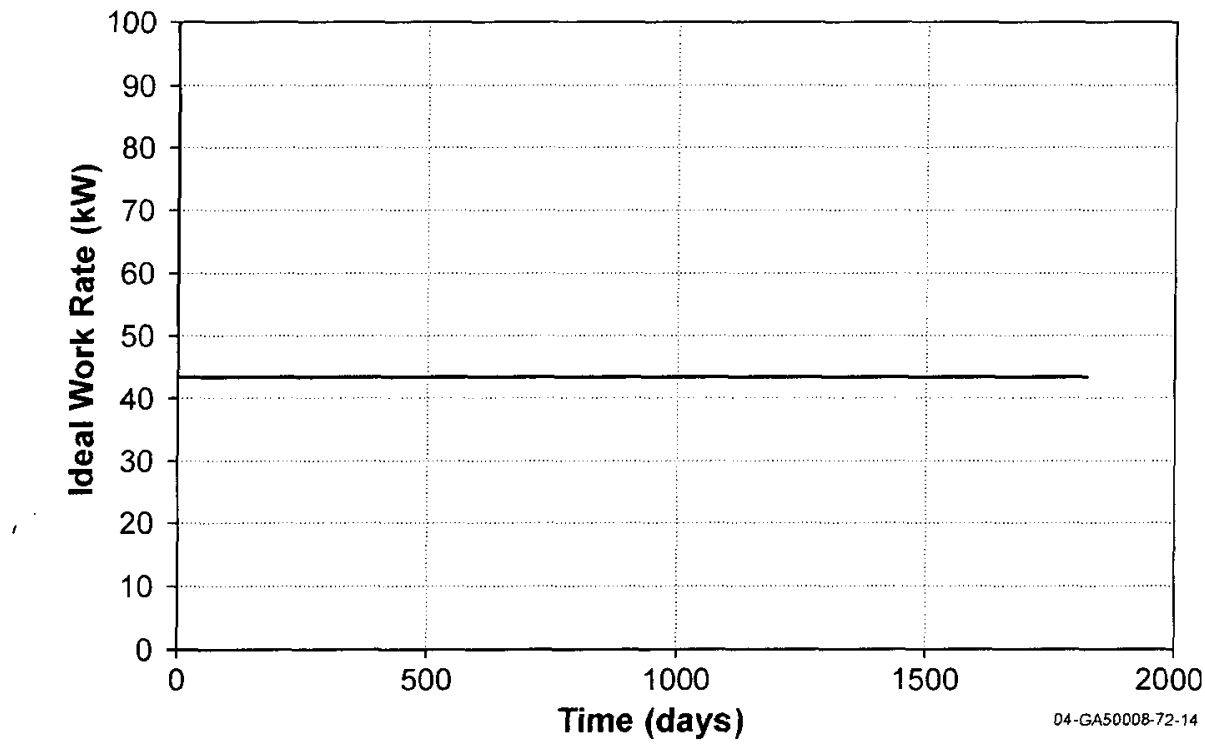

Figure 33. Ideal work extraction rate history for the near surface magma case showing the low PSS ideal work rate due to low effluent fluid temperature.

\subsection{Northwest Geysers Environment}

The Northwest Geysers are another potential site for a wellbore heat exchanger. Therefore, we conducted this case study to determine the viability of a wellbore heat exchanger in a vapor-dominated environment. The Geysers have two types of reservoirs, a normal vapor-dominated reservoir (NVDR) and a high-temperature reservoir (HTR). The NVDR studied was located at a formation depth of $30.48 \mathrm{~m}$ $(100 \mathrm{ft})$ and had a thickness of $1,828.8 \mathrm{~m}(6,000 \mathrm{ft})$. The HTR studied was below the NVDR and had a thickness of $609.6 \mathrm{~m}(2,000 \mathrm{ft})$. The NVDR temperature varied from $240^{\circ} \mathrm{C}\left(464^{\circ} \mathrm{F}\right)$ at the top to $250^{\circ} \mathrm{C}$ $\left(482^{\circ} \mathrm{F}\right)$ at the bottom, and the HTR temperature varied from $250^{\circ} \mathrm{C}\left(482^{\circ} \mathrm{F}\right)$ to $350^{\circ} \mathrm{C}\left(662^{\circ} \mathrm{F}\right)$. The formation had a homogenous permeability of $4.935 \mathrm{e}-14 \mathrm{~m}^{2}(50 \mathrm{mD})$ and a porosity of 0.02 . The model did not allow the formation fluids to flow into the wellbore, since the wellbore heat exchanger is designed to extract heat through thermal conduction only. The well radial geometry of the base case was adopted with a circulation rate of $100 \mathrm{gpm}(6.3 \mathrm{~kg} / \mathrm{s})$. The pressure at the tubing top was maintained at $34.1 \mathrm{~atm}$ (501 psia) to maintain single-phase conditions in the wellbore. The formation consisted of a vapor phase, wherein the liquid water was injected into the annulus and thermal energy was extracted from the formation in the vicinity of the wellbore. This resulted in condensation of the vapor phase in the formation, which then propagated laterally into the formation with time. The heat losses from the formation depth of $30.48 \mathrm{~m}$ (100 ft) to the surface were ignored, and the ideal energy was calculated with respect to the ambient conditions of $26.7^{\circ} \mathrm{C}\left(80^{\circ} \mathrm{F}\right)$ and $1.0 \mathrm{~atm}(14.7 \mathrm{psi})$. Figure 34 shows the produced fluid temperature history and Figure 35 is a plot of the ideal work rate history. The simulation was conducted for 245 days, at which time the PSS was attained. The decline rate for effluent temperature beyond 150 days was $0.012^{\circ} \mathrm{C} /$ day $\left(0.022^{\circ} \mathrm{F} /\right.$ day $)$. As shown in the plots, the fluid return temperature at 245 days was $76.0^{\circ} \mathrm{C}\left(168.8^{\circ} \mathrm{F}\right)$, and the ideal work extraction rate history is $118.5 \mathrm{~kW}(404.4 \mathrm{e}+3$ BTU/h). These output values are below the performance of the base case wellbore heat exchanger and hence not an attractive option. 


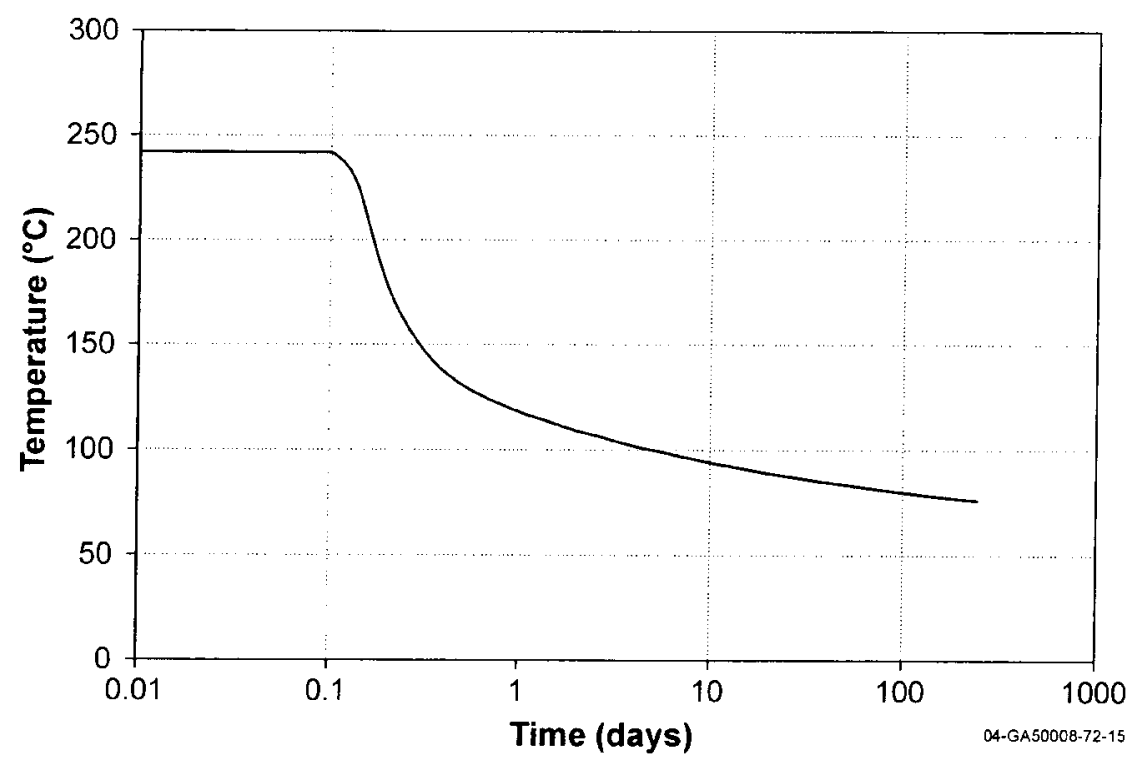

Figure 34. Produced fluid temperature history for the northwest geysers case.

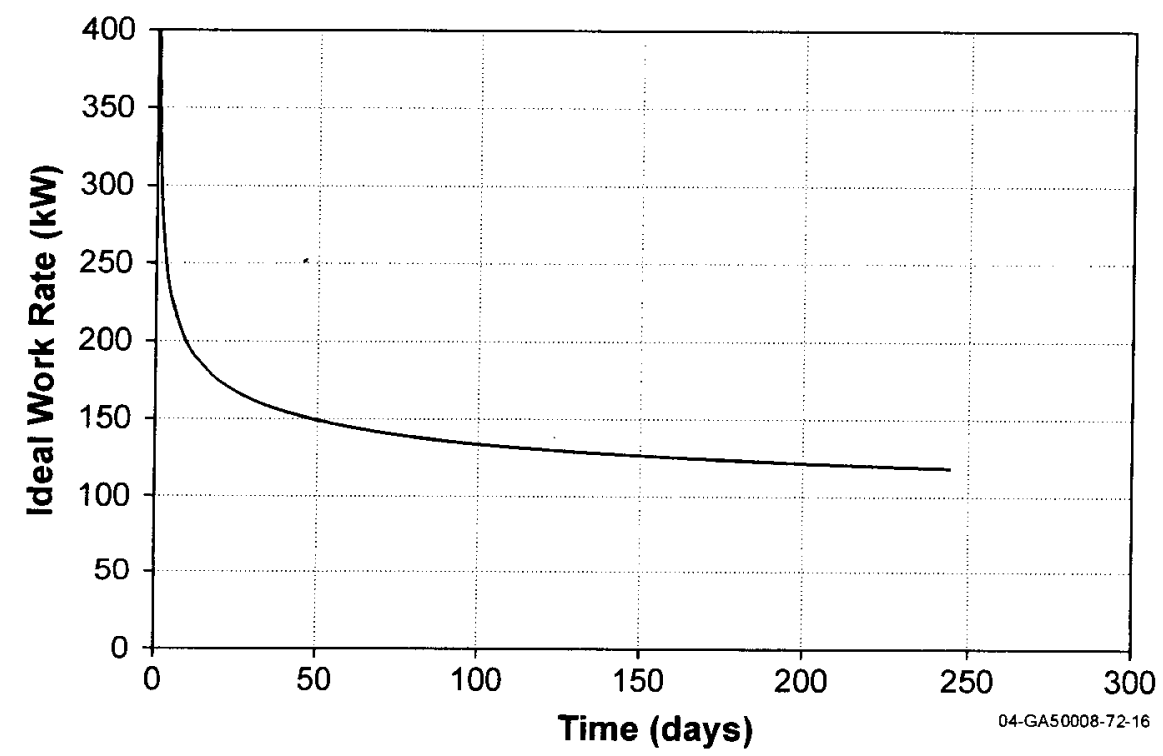

Figure 35. Ideal work extraction rate history for the northwest geysers case. 


\section{ELECTRIC POWER GENERATION}

Thermodynamics can be used to show that a heat engine working between an energy source and an energy sink cannot completely convert the heat extracted from the energy source into work (or power). The second law of thermodynamics allows one to quantify the limit placed on the conversion of heat to work through the definition of available energy. Available energy is that portion of energy that could be converted into work by ideal processes, which bring the energy source to a dead state-a state in equilibrium with the earth and its atmosphere. This available energy or ideal work rate represents the maximum power that an energy conversion system could produce when using an energy source (geothermal) to generate electricity. For power conversion in a turbogenerator unit, a reasonably highpressure vapor phase must be created from the produced liquid fluid by either flashing it to a lower pressure or by exchanging heat to another secondary fluid vaporizing at a lower temperature. Using the best case scenario discussed in the previous section, we reviewed the following different ways of analyzing the electric power generation capability of a wellbore heat exchanger:

- Abe et al. (1999) made several important observations about the thermal energy production and its conversion to electrical energy in hot dry-rock systems. According to their study, a resource that can return water to the surface at temperatures in the range of $150^{\circ} \mathrm{C}\left(302^{\circ} \mathrm{F}\right)$ or higher, appear to be a minimum requirement for electrical power production using current technologies, and temperatures around $80-90^{\circ} \mathrm{C}\left(176-194^{\circ} \mathrm{F}\right)$ could be practical for direct use applications. They also suggested that even a small commercial geothermal power plant, such as a $5 \mathrm{MW}(1.70607 \mathrm{e}+7$ $\mathrm{BTU} / \mathrm{h})$ plant producing electricity from water at $150^{\circ} \mathrm{C}\left(302^{\circ} \mathrm{F}\right)$, would require flow rates on the order of $2,378 \mathrm{gpm}(137.5 \mathrm{~kg} / \mathrm{s})$. These requirements on the produced fluid temperatures would apply to the wellbore heat exchanger system as well. At the onset of PSS for the best case WBHX, fluid temperature is approximately $98^{\circ} \mathrm{C}\left(208.4^{\circ} \mathrm{F}\right)$ with a circulation rate of $100 \mathrm{gpm}(6.3 \mathrm{~kg} / \mathrm{s})$. This output is far below the recommended criteria for temperatures and circulation rates $\left(150^{\circ} \mathrm{C}\right.$ $\left[302^{\circ} \mathrm{F}\right]$ at $\left.2,378 \mathrm{gpm}[137.5 \mathrm{~kg} / \mathrm{s}]\right)$ set by Abe et al.

- Based on data of existing low-temperature power generating facilities, we estimated the expected power generation from best case WBHX. What information is available on low-temperature generating facilities is summarized in Table 9 (taken from http://www.geothermie.de/egecgeothernet/prof/small geothermal power.htm). The conversion rate $(\eta)$ in Table 9 is defined as fluid circulation rate $(\mathrm{q})$ required per unit of power $(\mathrm{W})$ or:

$\eta=\frac{q}{W}$

Table 9. Commercial low-temperature operating specifications

\begin{tabular}{|l|c|c|c|c|}
\hline Plant & $\begin{array}{c}\text { Fluid Temperature } \\
\left({ }^{\circ} \mathrm{C}\right)\end{array}$ & $\begin{array}{c}\text { Circulation Rate } \\
(\mathrm{gpm})\end{array}$ & $\begin{array}{c}\text { Power Generation } \\
(\mathrm{kW})\end{array}$ & $\begin{array}{c}\text { Conversion Rate } \\
\eta(\mathrm{gpm} / \mathrm{kW})\end{array}$ \\
\hline Fang, Thailand & 115 & 264 & 300 & 0.88 \\
\hline Nagqu, Tibet & 110 & 1,100 & 1,000 & 1.1 \\
\hline Amedee, Ca. & 104 & 3,200 & 1,500 & 2.13 \\
\hline
\end{tabular}


Using the operational parameters for Amedee, $\mathrm{Ca}$. (at $104^{\circ} \mathrm{C}\left[219^{\circ} \mathrm{F}\right]$ ) closest to our best case in producing temperature), we calculate our maximum expected power generation rate from WBHX as follows:

$$
\mathrm{W}=\frac{\mathrm{q}}{\eta}=\frac{100 \mathrm{gpm}}{2: 133}<50 \mathrm{~kW}
$$

Thus, for what appears to be the optimum set of operating conditions, the WBHX can generate less that $50 \mathrm{~kW}(170.61 \mathrm{e}+3 \mathrm{BTU} / \mathrm{h})$ at the onset of PSS.

- $\quad$ Figure 36 obtained from Nichols (1986), plots the potential net power output that could be expected at a given flow rate and fluid temperature. In the best case WBHX, with a fluid temperature of $98^{\circ} \mathrm{C}\left(208^{\circ} \mathrm{F}\right)$ and $100 \mathrm{gpm}(6.3 \mathrm{~kg} / \mathrm{s})$ circulation rate at the onset of PSS, the potential net power output is approximately $50 \mathrm{kWe}(170.6 \mathrm{e}+3 \mathrm{BTU} / \mathrm{h})$. At 5 years, the fluid temperature falls to $86^{\circ} \mathrm{C}\left(187^{\circ} \mathrm{F}\right)$. At this temperature the minimum expected flow rate to estimate the potential power output $(64 \mathrm{kWe}(218.4 \mathrm{e}+3 \mathrm{BTU} / \mathrm{h}))$ is $300 \mathrm{gpm}(18.9 \mathrm{~kg} / \mathrm{s})$. Due to the declining fluid temperature, at a flow rate of $100 \mathrm{gpm}(6.3 \mathrm{~kg} / \mathrm{s})$ the electrical power output keeps declining from $50 \mathrm{kWe}(170.6 \mathrm{e}+3 \mathrm{BTU} / \mathrm{h})$ at 500 days until it becomes not viable to produce at later time. Thus the WBHX generates an estimated net power output less than $50 \mathrm{kWe}(170.6 \mathrm{e}+3$ BTU/h) during PSS.

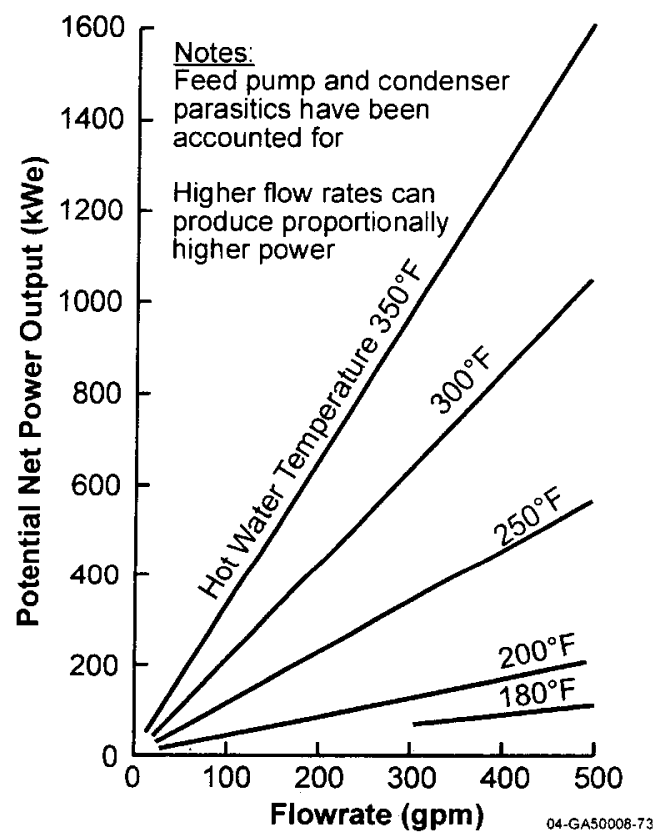

Figure 36. Potential net power output vs. flow rate (Nichols 1986)

Based on the above arguments, we were able to draw the following observations:

- A best case WBHX design produces both circulation rates and fluid temperatures far below those used in low-temperature power plants.

- $\quad$ Even assuming an ideal energy conversion process, a WBHX produces less than $200 \mathrm{~kW}$ $(682.4 \mathrm{e}+3 \mathrm{BTU} / \mathrm{h})$ of power at PSS. Using realistic conversion rates, it is likely the WBHX can generate less than $50 \mathrm{~kW}(170.6 \mathrm{e}+3 \mathrm{BTU} / \mathrm{h})$ at PSS, and that rate declines with time. 
- Based on existing technology, it is suggested that the wellbore heat exchanger is best suited for direct use applications. It is not economically viable for electric power generation.

\section{MODEL LIMITATIONS}

Our model assumed an equivalent Fourier's law of heat conduction at the solid-fluid interface in the place of Newton's law of cooling. The predominant heat transfer mechanisms are the thermal conduction from the formation towards the wellbore and fluid advection in the wellbore. Appendix A describes the heat transfer coefficients in the wellbore.

Two phase flow regimes in the wellbore were not incorporated into the model. For this study, the maximum temperature of fluid was $350^{\circ} \mathrm{C}\left(662^{\circ} \mathrm{F}\right)$. The saturation pressure of water at $350^{\circ} \mathrm{C}\left(662^{\circ} \mathrm{F}\right)$ is $2,400 \mathrm{psia}(16,547 \mathrm{kPa})$. The pressure and temperature of the fluid in the wellbore was such that only single phase conditions were possible; hence, the two phase correlations were not required. Also, flashing is not recommended in wellbore heat exchangers because it reduces available energy by increasing entropy.

The frictional pressure losses were not included in the model. The goal of this study is to evaluate the maximum possible ideal work extraction rate, and therefore, the parasitic loads were not even considered. Hence, the frictional pressure drop losses, which would affect the input power requirements and parasitic load, are considered negligible in this study. 


\section{SUMMARY AND CONCLUSIONS}

We developed a numerical model to investigate the potential for power generation using a wellbore as a heat exchanger and conducted a variety of sensitivity studies to obtain an understanding of variations in operational and regional properties and how they affect heat transfer. On the basis of these studies, we have drawn the following specific conclusions:

- There is a tradeoff between circulation and energy extraction rates, which implies that an intermediate optimum circulation rate exists that maximizes heat transfer to the circulating fluid.

- For fixed circulation rates, any increases in residence time of the fluid and contact surface area in the wellbore enhances energy extraction; this includes wellbore diameter and/or depth.

- $\quad$ For fixed bottomhole temperature, lower basal heat flux is better because it leads to deeper wells and longer residence times.

- Minimum tubing insulation is required, but enhancements to either insulation or changes in diameter affect the process insignificantly at optimum circulation rates.

- Energy extraction is very sensitive to formation thermal properties. Larger thermal conductivities and larger thermal diffusivities lead to improved energy extraction.

- Tradeoffs exist between the heat capacity of the working fluid and the extraction temperature. Water appears to have optimal or near optimal properties to provide reasonable energy density at acceptable temperatures.

- A best case WBHX design uses circulation rates far below any low-temperature power plants, and also produces fluid temperatures below plant operations. Even assuming ideal conversion of the thermal energy, a WBHX produces less than $200 \mathrm{~kW}(682.4 \mathrm{e}+3 \mathrm{BTU} / \mathrm{h})$ of power at PSS. Using realistic conversion rates, it is likely the WBHX can generate less than $50 \mathrm{~kW}(170.6 \mathrm{e}+3 \mathrm{BTU} / \mathrm{h})$ at PSS, and that rate declines with time. 


\section{REFERENCES}

Abe, H., D. V. Duchane, R. H. Parker, and M. Kuriyagawa, 1999, "Present Status and Remaining Problems of HDR/HWR System Design," Geothermics, Vol. 28, pp. 573-590.

Bobok, E., and A. Toth, 2002, "Geothermal Energy from Dry Holes: A Feasibility Study," GRC Trans., Vol. 26, pp. 275-278.

Carslaw, H. S. and J. C. Jaeger, 1959, Conduction of Heat in Solids, 2nd Edition, Oxford Press.

Lide, D. R., 1993, CRC Handbook of Chemistry and Physics, 73rd edition, CRC Press.

Kanev, K., J. Ikeuchi, S. Kimura, and A. Okajima, 1997, "Heat Loss to the Surrounding Rock Formation from a Geothermal Wellbore," Geothermics, Vol. 26, pp. 329-349.

Kohl, T., R. Brenni, and W. Eugster, 2002, "System Performance of a Deep Borehole Heat Exchanger," Geothermics, Vol. 31, pp. 687-708.

Lake, Larry W., 1989, Enhanced Oil Recovery, Prentice Hall, New Jersey.

Lund, J. W., 2003, "The Use of Downhole Heat Exchangers," Geothermics, Vol. 32, pp. 535-543.

Prats, M., 1986, “Thermal Recovery," Monograph, Vol. 7, Henry L. Doherty Series, Society of Petroleum Engineers.

Ramey, H. J., Jr., 1961, “Wellbore Heat Transmission,” 36th Annual Fall Meeting of SPE, October 8-11.

Nichols, K. E., 1986. "Wellhead Power Plants and Operating Experience at Wendel Hot Springs," GRC Trans., Vol. 10, pp. 341-346.

Mondy, L.A., and L. E. Duda, 1984, Advanced Wellbore Thermal Simulator GEOTEMP2 User Manual, Sandia Report.

Vinsome, P. K. W., and G. M. Shook, 1993, "Multi-purpose Simulation," Journal of Petroleum Science and Engineering, Vol. 9, pp. 29-38. 


\section{Appendix A}

\section{Heat Transfer Coefficient}




\section{Appendix A}

\section{Heat Transfer Coefficient}

The overall heat transfer coefficient for the wellbore heat exchanger was calculated using Equation A-1 (Lake 1989):

$$
\frac{1}{U_{T t o}}=R_{t o}\left\{\frac{1}{R_{t i} h_{T f}}+\frac{\ln \left(\frac{R_{t o}}{R_{t i}}\right)}{K_{T t}}+\frac{\ln \left(\frac{R_{i}}{R_{t o}}\right)}{K_{T i}}+\frac{1}{R_{i n s . o} h_{T a}}+\frac{\ln \left(\frac{R_{c o}}{R_{c i}}\right)}{K_{T c}}+\frac{\ln \left(\frac{R_{d}}{R_{c o}}\right)}{K_{T c e m}}\right\}
$$

The overall heat transfer coefficient for the base case was calculated using the following data:

$$
\begin{array}{ll}
R_{r i}=0.0381 \mathrm{~m} & K_{f}=0.67 \mathrm{~W} / \mathrm{m}^{0}{ }^{0} \mathrm{C} \\
R_{t o}=0.0445 \mathrm{~m} & \mu_{f}=10^{-3} \mathrm{~kg} / \mathrm{m} . \mathrm{sec} \\
R_{i n s, o}=0.0508 \mathrm{~m} & C_{p f}=4186 \mathrm{~J} / \mathrm{Kg} .{ }^{0} \mathrm{C} \\
R_{c i}=0.1143 \mathrm{~m} & K_{\mathrm{Tt}}=44.83 \mathrm{~W} / \mathrm{m}^{0} \mathrm{~K} \\
R_{c o}=0.1222 \mathrm{~m} & K_{\mathrm{Tins}}=0.07 \mathrm{~W} / \mathrm{m}^{0} \mathrm{~K} \\
R_{d}=0.1556 \mathrm{~m} & K_{\mathrm{Tcas}}=44.83 \mathrm{~W} / \mathrm{m}^{0} \mathrm{~K} \\
\dot{m}=6.30665 \mathrm{Kg} / \mathrm{sec} & K_{\mathrm{Tcem}}=0.8654 \mathrm{~W} / \mathrm{m}^{0} \mathrm{~K}
\end{array}
$$

The heat transfer coefficients for the fluid in the tubing and annulus were calculated using the Dittus-Boelter equation relating the Nusselt number, Prandtl number, and Reynolds numbers as follows:

$$
N_{\mathrm{Re}}=\frac{4 \dot{m}}{\pi D \mu} \quad N_{\mathrm{Pr}}=\frac{C_{p f} \mu_{f}}{K_{f}} \quad N_{N u}=\frac{h D}{K_{f}}
$$

Dittus-Boelter Equation: $N_{N u}=0.023 N_{\mathrm{Re}}^{4 / 5} N_{\mathrm{Pr}}^{0.4}$

\section{Tubing}

$$
\begin{aligned}
& N_{\mathrm{Re}}=105336.6 \\
& N_{\mathrm{Pr}}=6.248 \\
& N_{N u}=498.98 \\
& h_{T f}=4387.334 \mathrm{~W} / \mathrm{m}^{2} \cdot{ }^{\circ} \mathrm{C}
\end{aligned}
$$




\section{Annulus}

Top cased portion:

$$
\begin{aligned}
& N_{\mathrm{Re}}=63,201.93 \\
& N_{\mathrm{Pr}}=6.248 \\
& N_{N_{u t}}=331.59 \\
& h_{\text {Ta.top }}=2186.67 \mathrm{~W} / \mathrm{m}^{2} .{ }^{\circ} \mathrm{C}
\end{aligned}
$$

\section{Bottom open portion:}

$$
\begin{aligned}
& N_{\mathrm{Re}}=38,295.1 \\
& N_{\mathrm{Pr}}=6.248 \\
& N_{N u}=222.1 \\
& h_{\text {Ta.bottom }}=1464.6 \mathrm{~W} / \mathrm{m}^{2} \cdot{ }^{\circ} \mathrm{C}
\end{aligned}
$$

\section{Overall Heat Transfer Coefficient}

Equation A-1 was used to calculate the overall heat transfer coefficient for the cased portion and the open portion of the well. The values determined are:

$$
\begin{aligned}
& U_{T, \text { cased }}=10.258 \mathrm{~W} / \mathrm{m}^{2} \cdot{ }^{\circ} \mathrm{C} \\
& U_{T, \text { open }}=11.7383 \mathrm{~W} / \mathrm{m}^{2} \cdot{ }^{\circ} \mathrm{C}
\end{aligned}
$$




\section{Appendix B \\ Sample Input File (Base case)}




\title{
Appendix B
}

\section{Sample Input File (Base case)}

\begin{abstract}
'NOMESS'
'DIAGN' 1

'SLE'

'DELX' 29

10.0500

10.0500

10.0250

10.0210

10.0210

10.0500

10.0500

10.0500

10.0290

10.0290

10.0260

10.0300

10.0350

10.0440

I 0.0640

10.0970

10.1450

10.2170

10.3260

10.4890

10.7330

11.1000

11.6500

12.4750

13.7120

15.5680

18.3520

110.4170

114.1450
\end{abstract}

'COMMENT' '************************************************************************'

COMMENT '***************** USING TETRAD VERSION $13.3 * * * * * * * * * * * * * * * * * \cdots$

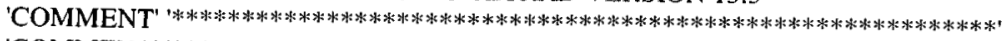

'COMMENT' ${ }^{\prime} * * * * * * * * * * * * * * *$ RESERVOIR INPUT DATA $* * * * * * * * * * * * * * * * * * * * * * * * * 1$

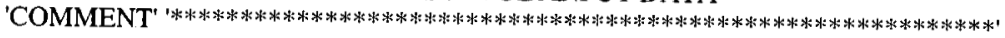

'COMMENT' $\cdot$

'COMMENT' 'TTYPE NC NCW WT9 WT9RA'

'TYPE' 4110.00 .0

'COMMENT' ' NX NY NZ NTM '

'DIMEN' 29118650000

'DELZ' 3

$183183 * 100$

$22 * 20$

$11 * 10$

'FTOPS' 11

10.

'RADIAL' $1,,,$,

'COMMENT"'

'COMMENT" 'IMETR IPABS ITABS IRATEU '

'UNITS' 0101

'COMMENT' 'NPR IOXZ IFIELD IOVER IDBG '

'PRINT' 01000

'COMMENT' ' P SW SG SO W Y X T WELL AQUIF'

'OUTFUN' 32000 Q 0490

'COMMENT' 'PHI RK PC DEN MW VIS H U TCON HLOSS '

'COMMENT' 'PFLUX KVAL SPAR3 SPAR4 FADS SPAR6 SPAR7 SPAR8 SPAR9 DIFFBC' 'OUTMISC' 5 ,.,.,.,.,.,.,

'COMMENT" 'IWELL IAQUIF IFPROD IFINJ MATRIX IFRAC MAFR ISPARE ITR ISEP' 'OUTGEO' 0000000000 
'COMMENT" $"$

COMMENT"

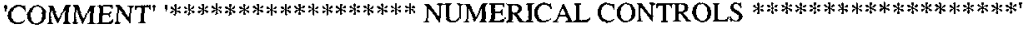

'COMMENT' $"$ '

'COMMENT",

'COMMENT' 'ANORP ANORS ANORX ANORT'

'NORM' -0.30 .050 .0530 .0$

'COMMENT' 'NREPMX NRESMX DTMAX FLOWMX FLGMX DTMMUL ITSSUP'

'TMSTEP' $330.0 .,, .,,$,

'COMMENT' 'NEWTMX CTOL DAMPMN'

'NEWT' 150.01 .00

'COMMENT' 'MXITI MXITO NORD CTOLIT DPTOLI'

'TTER' 30302.00010 .00001

'COMMENT' '************** PERMEABILITY/POROSITY ***********************'

'COMMENT' ",

'COMMENT' ' NLINE POR PERMX PERMY PERMZ

'PORKASS' 10.0 1.0e-5 1.0e-5 1.0e-5

153941

'COMMENT' II I2 I3

'PERMMOD' 15394290.010 .01500000000 . 'cells 1 to 3 '

'PERMMOD' 25394290.010 .01500000000 . 'inside tubing'

'PERMMOD' 35394290.010 .01500000000$.

'PERMMOD' 4536529 1.0E-5 1.0E-5 1.0E-5 'tubing'

'PERMMOD' 5536529 1.0E-5 1.0E-5 1.0E-5 'insulation'

'PERMMOD' 65394290.010 .01500000000 . 'cells 6 to 10 '

'PERMMOD' 75394290.010 .01500000000 . 'annulus '

'PERMMOD' 85394290.010 .01500000000$.

'PERMMOD' 95394290.010 .01500000000$.

'PERMMOD' 105394290.010 .01500000000$.

'PERMMOD' 1172529 1.0E-5 1.0E-5 1.OE-5

'PERMMOD' 1272529 1.0E-5 1.0E-5 1.0E-5

'PERMMOD' 1372529 1.0E-5 1.0E-5 1.0E-5

'PERMMOD' 1472529 1.0E-5 I.0E-5 1.0E-5

'PERMMOD' 7365394290.010 .01500000000$.

'PERMMOD' 7375394290.010 .01500000000$.

'PERMMOD' 7385394290.010 .01500000000$.

'PERMMOD' 7395394290.010 .01500000000$.

'PORMOD' 15394291

'PORMOD' 25394291.

'PORMOD' 35394291 .

'PORMOD' 45365290 'tubing'

'PORMOD' 55365290 'insulation'

'PORMOD' 65394291.

'PORMOD' 75394291.

'PORMOD' 85394291.

'PORMOD' 95394291.

'PORMOD' 105394291.

'PORMOD' 11725290 0. 'casing'

'PORMOD' 12725290 . 'casing'

'PORMOD' 13725290 0. 'casing'

'PORMOD' 1472529 0. 'cement'

'PORMOD' 7365394291 . 'below the casing and cement is fluid'

'PORMOD' 7375394291 .

'PORMOD' 7385394291 .

'PORMOD' 7395394291 .

'PORMOD' 5366537511 .

'PERMMOD' 131500000000.500000000 .500000000

'PERMMOD' 536653751500000000 . 500000000. 500000000.

'COMMENT' I1 I2 I3 JDIR TMULT

'TMULT' 3536529 I -1.0

'TMULT' $55365291-1.0$

'TMULT' $145394291-1.0$

'COMMENT' '******************************************************************

'COMMENT' $* * * * * * * * * * * * * * * * * * * *$ PROPERTY SECTION $* * * * * * * * * * * * * * * * * * * * * * '$

'COMMENT' '*********************************************************************

'COMMENT' $"$

'EXMBAL' 1

'PROPERTY'

'COMMENT' $\cdot$ '

'COMMENT' ', 
'COMMENT' $1 * * * * * * * * * * * * * * * * * * *$ REL PERM AND PVT $* * * * * * * * * * * * * * * * * * * * * * * * * 1$

'RELANAL' 01010

280. 280.

0.01 .03 .0

0.00 .01 .00 .1 .0

0.00 .02 .5

0.00 .01 .00 .1 .0

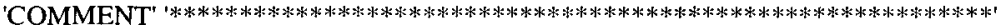

'COMMENT' 'I1 I2 I3 SG SO'

'SATMOD' 1539410.0

'COMMENT' '************ SPECIFY INITIAL PRESSURE GRADIENT **************'

'COMMENT' ' P DEPTH PGRAD '

'PRES' 14.7 0. 0.433

'COMMENT' ' T DEPTH TGRAD '

'TEMP' 80. 0. 0.03172 'temp grad based on heat flux $0.1 \mathrm{~W} / \mathrm{m} 2$ '

'DENCS' 62.43

18.015

'COMMENT' '

'LATHVAP' ALHB TCLHAB TBABS AN

,.,.,.,'

'COMMENT' 'ASHR BSHR TSHR DENR'

'LIQSH' .20 0. 32135

1. $0.0 . ., .$,

'GASSH'

0.560000

'COMMENT' ' '

'COMMENT' ' ATCR BTCR TTCR '

'LIQTCON' $24.0, \ldots$,

$9.408,,$,

'COMMENT' I1 22 I3 TCRMULT

'TCRMULT' 453652925.9 'tubing wall'

'TCRMULT' 55365290.0392 'insulation'

'TCRMULT' 117252925.9 'casing wall'

'TCRMULT' 12725290.5 'next three cement'

'TCRMULT' 13725290.5

'TCRMULT' 14725290.5

'COMMENT' 'ATCGC BTCGC TTCGC'

'GASTCON'

'CRITG'

'","',"'

'LIQDEN'

$62.43, \ldots, \cdots$,

'COMMENT'

'COMMENT' I1 12 L DENR

'DENRMOD' 4536529286.07

'DENRMOD' 5536529567.24

'DENRMOD' 1172529286.07

'DENRMOD' 127252994.0

'DENRMOD' 137252994.0

'DENRMOD' 147252994.0

'LIQVIS'

$1,,,,, \cdots, \cdot$,

'COMMENT" ",

'COMMENT" '******************************************************************'

'COMMENT' '********************** RECURRENT $* * * * * * * * * * * * * * * * * * * * * * * * '$

'COMMENT' '******************************************************************'

'RECUR'

'TIMEYR' 0

'TIME' 0. 0.0000001

'PRODUCER' 'PROD1' 13

1

$0.1526570 .025, \ldots$ 
100000 .

$0.4331, \ldots$,

'COMMENT' I1 I2 I3 JDIR AMFLUX

'MFLUX' $610133.392213 \mathrm{e} 6$

'COMMENT' I1 I2 I3 ENFLUX

'ENFLUX' $61011.6282027 \mathrm{e} 6$ 'water injection in the annulus'

'ENFLUX' 5366539410.076123 'energy flux input - bottom'

'COMMENT' 'TYPECB' I1 I2 I3 JDIRCB TCBTHR TCCB TCCBMD SHCB DENCB TCB ALCB

'HLOSS' SSTATE $1291-30.0,,,,,,,,,$,

'COMMENT' 'NAMEW' HLW PBHCW QCMXW

'P' 'PROD1' 0. 14.70.

'GEOSEP' 'P' - 14.676620 .0

1 'PRODI'

'PLOT' 30

9 'QWPMASS' 'QWPENER' 'QTOTMASS' 'QTOTENER' 'CTOTENER' 'QWSVOL' 'TAV' 'PBHW' 'PAV'

'GVWRITE' 0150

3 'T' 'P' 'SG'

'TIME' $0.01-1.0$

'TIME' $0.1-1.0$

'TIME' 1. - 1.0

'TIME' 5. -1.0

'TIME' 10. -1.0

'TIME' 25. -1.0

'TIME' 50. - 1.0

'TIME' 100. -1.0

'TIME' 200. - 1.0

'TIME' 300. -1.0

'TIME' 400. -1.0

'TIME' 500. - 1.0

'TIME' 600. -1.0

'TIME' 700. -1.0

'TIME' 800. -1.0

'TIME' 900, -1.0

'TIME' 1000. -1.0

'TIME' 1250. - 1.0

'TIME' 1500. -1.0

'TIME' 1750. - 1.0

'TIME' 1825. 0.0 


\section{Appendix C}

Calculation of the Average Formation Heat Transfer Due to Conduction and Proof of the Primary Effect of Wellbore Depth Compared to the Secondary Effect of Geothermal Gradient 


\section{Appendix C}

\section{Calculation of the Average Formation Heat Transfer Due to Conduction and Proof of the Primary Effect of Wellbore Depth Compared to the Secondary Effect of Geothermal Gradient}

In order to prove the higher order effect of the wellbore depth compared to the high geothermal gradient, a simple calculation was done and is given below.

From Carslaw and Jaeger (chapter VII, 1959), the equation for steady state heat flow rate in an infinite circular cylinder with fixed temperatures at two different radii is given. The wellbore heat exchanger could be simplified to this model just for this calculation. At the wellbore radii, the temperature could be assumed to be the circulation temperature and at the outer radii of the formation the temperature could be considered to be the initial formation temperature. The calculations are as follows:

Radial Flow of heat in a circular cylinder at steady state

$r=r_{1}$ kept at temperature $T_{1}$ and

$r=r_{2}$ kept at temperature $T_{2}$

The rate of flow of heat per unit length is given by

$q_{H}=-2 \pi K \frac{d T}{d r}=\frac{2 \pi K\left(T_{1}-T_{2}\right)}{\ln \left(r_{2} / r_{1}\right)}$

At steady state conditions, in the wellbore heat exchanger, the following assumptions are made

At $r_{1}=r_{w}, T_{1}=T_{J}$

At $\left.r_{2}=r_{e}, T_{2}=T_{I}(z)\right\}$

where

$r_{w}=$ Well radius,

$r_{e}=$ Formation external radius considered in the wellbore model,

$T_{J}=$ Injection temperature

$T_{I}(z)=$ Formation initial temperature at depth $z$

$$
=T_{\text {surface }}+\left(\frac{d T}{d z}\right) * z
$$

Assume that the injected fluid is at the ambient conditions,

$T_{\text {sufface }}=T_{J}$ 
The steady state heat transfer due to conduction for a discrete element of thickness $\Delta z$ with a small residence time of $\Delta \tau$

$$
\begin{aligned}
& \Delta Q_{H}=\left.q_{H}\right|_{z} ^{*} \Delta \tau * \Delta z \\
& \Delta Q_{H}=\frac{2 \pi K\left(T_{I}(z)-T_{J}\right)}{\ln \left(r_{e} / r_{w^{\prime}}\right)} * \Delta \tau * \Delta z
\end{aligned}
$$

$K=$ Formation thermal conductivity

Equation (II) is integrated in order to calculate the total heat transferred due to conduction along the entire wellbore depth and for complete fluid residence time,

$$
\begin{aligned}
Q_{H} & =\int_{z=0}^{H} \int_{\tau=0}^{\tau_{\text {res }}} \Delta Q_{H} \\
& =\int_{z=0}^{H} \int_{\tau=0}^{\tau_{\text {res }}} \frac{2 \pi K\left(T_{I}(z)-T_{J}\right)}{\ln \left(r_{e} / r_{w}\right)} * \Delta \tau * \Delta z
\end{aligned}
$$

Substituting relations (2) and (3) into equation (III) gives

$Q_{H}=\int_{z=0}^{H} \int_{\tau=0}^{\tau_{r e s}} \frac{2 \pi K}{\ln \left(r_{e} / r_{w}\right)} *\left(\left(\frac{d T}{d z}\right) * z\right) * \Delta \tau * \Delta z$

The limits of integration are

$\tau$ goes from 0 to $\tau_{\text {res }}$ where

$\tau_{\text {res }}=\frac{A_{c r} * H}{q_{v o l}}$

$\tau_{\text {res }}=$ Fluid residence time in the wellbore;

$H=$ Wellbore depth;

$A_{c r}=$ Cross sectional area of the wellbore;

$q_{v o l}=$ volumetric flow rate

$\mathrm{z}$ goes from 0 to $\mathrm{H}$

On Integration and using relation (4), equation (IV) simplifies to

$$
\begin{aligned}
Q_{H} & =\left.\left(\frac{2 \pi K}{\ln \left(r_{e} / r_{w}\right)} *\left(\frac{d T}{d z}\right) * \tau * z^{2} /\left.2\right|_{0} ^{\tau}\right)\right|_{0} ^{H} \\
Q_{H} & =\frac{\pi K}{\ln \left(r_{e} / r_{w}\right)} *\left(\frac{d T}{d z}\right) * \frac{A_{c r} * H}{q_{v o l}} * H^{2} / 2 \\
Q_{H} & =\left(\frac{\pi K}{\ln \left(r_{e} / r_{w}\right)} \frac{A_{c r}}{q_{v o l}}\right) *\left(\frac{d T}{d z}\right) * H^{3} \ldots \ldots \ldots . . . .
\end{aligned}
$$


The next step is to calculate the formation conduction heat trans fer for a new basal heat flux with fixed bottom hole temperatu re. Let the new basal heat flux be $n$ times higher than the basecase basal heat flux

$$
\begin{aligned}
& q_{\text {basalH }}=K\left(\frac{d T}{d z}\right) \\
& q_{\text {basalH }, \text { new }}=K\left(\frac{d T}{d z}\right)_{\text {new }}=n * q_{\text {basalH }}=n * K\left(\frac{d T}{d z}\right) \\
& \Rightarrow\left(\frac{d T}{d z}\right)_{n e w}=n *\left(\frac{d T}{d z}\right) \\
& \left(\frac{T_{\text {BottomHole }}-T_{\text {surface }}}{H_{n e w}}\right)=n *\left(\frac{T_{\text {BottonHole }}-T_{\text {surface }}}{H}\right) \\
& \Rightarrow H_{n e w}=\frac{H}{n}
\end{aligned}
$$

The new total heat trans fer due to conduction in the formation for one fluid residence time is

$$
Q_{H, n e w}=\left(\frac{\pi K}{\ln \left(r_{e} / r_{w}\right)} * \frac{A_{c r}}{q_{v o l}}\right) *\left(\frac{d T}{d z}\right)_{n e w} * H_{n e w}{ }^{3}
$$

Substituting the relations (5) and (6) into equation (VI) gives

$$
\begin{aligned}
Q_{H, \text { new }}= & \left(\frac{\pi K}{\ln \left(r_{c} / r_{w}\right)} * \frac{A_{c r}}{q_{v o l}}\right) * n *\left(\frac{d T}{d z}\right) *\left(\frac{H}{n}\right)^{3} \\
Q_{\text {H.new }}= & \left(\left(\frac{\pi K}{\ln \left(r_{e} / r_{w}\right)} * \frac{A_{c r}}{q_{v o l}}\right) *\left(\frac{d T}{d z}\right) * H^{3}\right) / n^{2}
\end{aligned}
$$

Substituti ng equation (V) into (VI)

$$
Q_{H, \text { new }}=Q_{H} / n^{2}
$$

Therefore, increasing the basal heat flux for a fixed bottomhole temperature by a factor of $n$ resulted in a reduced total heat transferred by conduction from the formation. The reduction was caused due to the decreased contact surface area and fluid residence time. Therefore, the wellbore depth, in turn affecting the contact surface area and fluid residence time, has a higher influence on the heat transferred due to conduction than the geothermal gradient. 